UNIVERSIDADE DE SÃO PAULO

ESCOLA DE ENFERMAGEM

RENATA HOLANDA DOS ANJOS LIMA

CONHECIMENTO SOBRE AS VERDADEIRAS E FALSAS CONTRAINDICAÇÕES ÀS IMUNIZAÇÕES EM UMA UNIDADE BÁSICA DE SAÚDE

SÃO PAULO

2019 


\section{CONHECIMENTO SOBRE AS VERDADEIRAS E FALSAS CONTRAINDICAÇÕES ÀS IMUNIZAÇÕES EM UMA UNIDADE BÁSICA DE SAÚDE}

Dissertação apresentada ao Programa de Pós-Graduação Mestrado Profissional em Enfermagem na Atenção Primária em Saúde no Sistema Único de Saúde da Escola de Enfermagem da Universidade de São Paulo para obtenção do título de Mestre em Ciências da Saúde

Área de Concentração: Saúde Coletiva

Orientador: Prof. Dr. Francisco Oscar de Siqueira França, Coorientadora: Dra. Eloá Otrenti

\section{SÃO PAULO}

2019 
AUTORIZO A REPRODUÇÃO E DIVULGAÇÃO TOTAL OU PARCIAL DESTE TRABALHO, POR QUALQUER MEIO CONVENCIONAL OU ELETRÔNICO, PARA FINS DE ESTUDO E PESQUISA, DESDE QUE CITADA A FONTE.

Assinatura:

Data:

\section{Catalogação na Publicação (CIP) \\ Biblioteca "Wanda de Aguiar Horta" \\ Escola de Enfermagem da Universidade de São Paulo}

Lima, Renata Holanda dos Anjos

Conhecimento sobre as verdadeiras e falsas contraindicações às imunizações em uma unidade básica de saúde / Renata Holanda dos Anjos Lima. São Paulo, 2019. $103 \mathrm{p}$.

Dissertação (Mestrado) - Escola de Enfermagem da Universidade de São Paulo.

Orientador: Prof. Dr. Francisco Oscar de Siqueira França

Coorientadora: Dr. ․ㅡ Eloá Otrenti

Área de concentração: Saúde Coletiva

1. Imunização. 2. Atenção primária à saúde. 3. Centros de saúde. 4. Qualificação profissional. I. Título.

Ficha catalográfica elaborada por Fabiana Gulin Longhi Palacio (CRB-8: 7257) 
Nome: Renata Holanda dos Anjos Lima

Título: Conhecimento sobre as verdadeiras e falsas contraindicações às imunizações em uma Unidade Básica de Saúde.

Dissertação apresentada ao Programa de Pós-Graduação Mestrado Profissional em Enfermagem na Atenção Primária em Saúde no Sistema Único de Saúde da Escola de Enfermagem da Universidade de São Paulo para obtenção do título de Mestre em Ciências da Saúde.

Aprovado em:

\section{Banca Examinadora}

Orientador: Prof. Dr. Francisco Oscar de Siqueira França Instituição: Assinatura:

Prof. Dr. Instituição:

Julgamento: Assinatura:

Prof. Dr. Instituição:

Julgamento: Assinatura:

Prof. Dr. Instituição:

Julgamento: Assinatura: 


\section{AGRADECIMENTOS}

Agradeço à Deus, pois, sendo Ele o dono de toda ciência e sabedoria, me permitiu chegar ao fim desta caminhada!

Ao meu esposo, Tarcis, que sempre me incentivou, apoiou, e ajudou em tudo o que foi possível, enxergando, algumas vezes, potencial que nem eu mesmo via.

À minha filha, Betina, que, mesmo sem saber, me deu um novo significado e fôlego na caminhada.

Aos meus pais, que proporcionaram a base de tudo, para que eu pudesse continuar construindo e me desenvolvendo.

Ao meu orientador, Prof. Francisco, que há anos me ensina, orienta e corrige, sem desistir de mim.

À professora Maria Rita Bertolozzi, que esteve sempre presente, auxiliando na construção desse trabalho.

À Eloá, que, chegou um pouco depois nessa trajetória, trazendo mais conhecimento e riqueza a esta pesquisa. 


\section{EPÍGRAFE}

Pois dele, por ele e para ele são todas as coisas. A ele seja a glória para sempre! Amém.

Romanos 11:36 
Lima RHA. Conhecimento sobre as verdadeiras e falsas contraindicações às imunizações em uma Unidade Básica de Saúde. São Paulo: Escola de Enfermagem, Universidade de São Paulo; 2019.

\section{RESUMO}

O cumprimento do calendário vacinal no período estabelecido é uma ferramenta importante para a redução da mortalidade infantil, e a não efetivação deste objetivo pode gerar sérios problemas de saúde pública. Para garantir a imunização como proposta pelo $\mathrm{PNI}$, e evitar a oportunidade perdida em imunização, é preciso que tanto os profissionais que atuam diretamente na sala de vacina, como os que atuam na orientação da população sobre vacinação, estejam adequadamente informados sobre as verdadeiras e falsas contraindicações à vacinação. Este trabalho teve como objetivo identificar o conhecimento da equipe de enfermagem e dos agentes comunitários de saúde a respeito de imunizações. Trata-se de estudo com abordagem quantitativa do tipo descritivo-exploratório, com desenho pré e pósexposição, em amostra de conveniência. Participaram da pesquisa 39 agentes comunitários de saúde, 12 auxiliares de enfermagem e 4 enfermeiros. A pesquisa foi realizada através da aplicação de questionário individual, inicialmente; a seguir foi realizada ação educativa sobre imunização; e, por fim, o questionário foi reaplicado. Os dados foram tabulados e analisados por frequência simples. Pode-se observar que os participantes orientavam os responsáveis pelas crianças com falsas contraindicações à imunização, tais como doença e infecção na criança, pósoperatório, uso de antibiótico e antialérgico. Também se evidencia que os mesmos orientavam corretamente quanto às contraindicações ou adiamento nas seguintes situações: alergia à componente da vacina, questões de saúde específicas, febre e uso de corticoide. Todos os participantes demonstraram ciência e sensibilização quanto à importância do conhecimento dos pais ou responsáveis pela criança acerca das doenças imunopreveníveis e registro correto das vacinas aplicadas pelos profissionais. Houve aumento do conhecimento dos profissionais quanto à associação da redução da mortalidade infantil a maiores taxas de cobertura vacinal, recomendação de vacinar as crianças pequenas, interferência das crenças dos pais quanto a não importância ou não efetividade das vacinas na adesão à vacinação, aumento do risco de transmissão de doenças e reintrodução de doenças erradicadas quando não se permite a vacinação, controle de qualidade das vacinas aplicadas no SUS, oportunidade perdida de vacinação, responsabilidade da equipe de saúde na busca ativa de faltosos, importância do acolhimento dos profissionais para melhor adesão à vacinação e associação das vacinas com as doenças contra as quais protege. Durante a aplicação do questionário, algumas perguntas foram questionadas pelos participantes, e observou-se que a forma como foram elaboradas algumas questões pôde induzir a dúvidas nas respostas. Observou-se que houve aumento das respostas corretas por parte dos profissionais em $66,7 \%$ das questões, manutenção da totalidade de profissionais que responderam de forma adequada, antes e após a ação, em $8,3 \%$ das questões, e diminuição das respostas corretas em $25 \%$ das questões, sendo que neste último cenário, a maior parte das diminuições está relacionada à formulação incorreta das perguntas. Diante do exposto, considera-se que a ação educativa foi eficaz para o incremento do conhecimento dos profissionais sobre imunização, porém propõe-se adequação do instrumento de coleta de dados 
para maior clareza do conhecimento que se pretende avaliar em cada questão, e maior aproximação deste ao conteúdo da ação educativa.

PALAVRAS-CHAVE: Imunização. Atenção Primária à Saúde. Unidade Básica de Saúde. Capacitação. 
Lima RHA. Knowledge about the true and false contraindications to immunizations in a Basic Health Unit. São Paulo: School of Nursing, University of São Paulo; 2019.

\begin{abstract}
Compliance with the vaccination schedule within the established period is an important tool for reducing child mortality, and failure to achieve this goal can lead to serious public health problems. To ensure immunization as proposed by the PNI, and to avoid the missed opportunity in immunization, it is necessary that both professionals working directly in the vaccine room, as well as those guiding the population on vaccination, are adequately informed about the true and false contraindications to vaccination. This study aimed to identify the knowledge of the nursing staff and community health agents about immunizations. This is a study with a quantitative descriptive-exploratory approach, with pre and post-exposure design, in a convenience sample. The study included 39 community health agents, 12 nursing assistants and 4 nurses. The research was conducted by applying an individual questionnaire initially; next, an educational action on immunization was carried out; and finally, the questionnaire was reapplied. Data were tabulated and analyzed by simple frequency. It can be observed that the participants advised the children's responsible with false contraindications to immunization, such as postoperative illness and infection in children, antibiotic and antiallergic use. It is also evident that they correctly advised against contraindications or postponement in the following situations: allergy to the vaccine component, specific health issues, fever and corticosteroid use. All participants were aware of the importance of parents 'or guardians' knowledge about immunopreventable diseases and correct registration of vaccines applied by professionals. Professionals knowledge increased regarding the association of reduced infant mortality with higher rates of vaccination coverage, recommendation to vaccinate young children, interference of parents' beliefs about the importance or ineffectiveness of vaccines in vaccination adherence, increased risk transmission of diseases and reintroduction of diseases eradicated when vaccination is not allowed, quality control of vaccines applied in SUS, missed opportunity for vaccination, responsibility of health team in the active search for absentees, importance of welcoming professionals to better adhere to vaccination and association of vaccines with the diseases against which it protects. During the application of the questionnaire, some questions were asked by the participants, and it was observed that the way some questions were elaborated could induce doubts in the answers. It was observed that there was an increase in the correct answers by professionals in $66.7 \%$ of the questions, maintenance of all professionals who answered adequately, before and after the action, in $8.3 \%$ of the questions, and a decrease in the answers correct in $25 \%$ of the questions; and in this last scenario most of the decreases are related to the incorrect formulation of the questions. Given the above, it is considered that the educational action was effective to increase the knowledge of professionals about immunization, but it is proposed to adapt the data collection instrument for greater clarity of knowledge to be evaluated in each question, and greater approximation you gave to the content of the educational action.
\end{abstract}

KEY WORDS: Immunization. Primary Health Care. Primary Health Care Unit. Training. 


\section{LISTA DE ILUSTRAÇÕES}

Figura 1 - Supervisões Técnicas de Saúde do Município de São Paulo. São Paulo, 2019

Figura 2 - Estabelecimentos de Saúde da Coordenadoria

Regional de Saúde Sul, São Paulo, 2019

Figura 3 - Cobertura vacinal de determinados imunobiológicos. 2012-2016. São Paulo, 2019. 


\section{LISTA DE GRÁFICOS}

Gráfico 1 - Distribuição dos sujeitos do estudo segundo faixa etária. São Paulo, 2019

Gráfico 2 - Distribuição dos sujeitos do estudo segundo grau de escolaridade e formação na área da saúde. São Paulo, 2019

Gráfico 3 - Distribuição da categoria ACS segundo grau de escolaridade e formação na área da saúde. São Paulo, 2019

Gráfico 4 - Distribuição da categoria Auxiliar de Enfermagem segundo grau de escolaridade e formação na área da saúde. São Paulo, 2019

Gráfico 5 - Distribuição dos sujeitos do estudo segundo tempo de trabalho na função exercida. São Paulo, 2019

Gráfico 6 - Distribuição dos sujeitos do estudo segundo participação em ação educativa prévia sobre imunização. São Paulo, 2019

Gráfico 7 - Índice de acertos dos participantes sobre a 52 importância do conhecimento dos pais ou responsáveis pela criança acerca das doenças imunopreveníveis, questão 3. São Paulo, 2019.

Gráfico 8 - Índice de acertos dos participantes sobre 52 desenvolvimento da imunidade efetiva após a primeira dose de uma vacina, questão 4. São Paulo, 2019.

Gráfico 9 - Índice de acertos dos participantes sobre 53 erradicação de uma doença imunoprevenível em uma determinada localização em regiões com alta cobertura vacinal, questão 5. São Paulo, 2019. 

Gráfico 10 - Índice de acertos dos participantes sobre diminuição da mortalidade infantil associada a maiores coberturas vacinais, questão 6. São Paulo, 2019.

Gráfico 11 - Índice de acertos dos participantes sobre risco de vacinar crianças de pouca idade, questão 7. São Paulo, 2019.

Gráfico 12 - Índice de acertos dos participantes sobre 56 responsabilidade da equipe de saúde quanto à busca ativa de faltosos, questão 8. São Paulo, 2019.

Gráfico 13 - Índice de acertos dos participantes sobre responsabilidade da equipe de saúde quanto à orientação aos pais sobre as vacinas e as doenças imunopreveníveis, questão 9. São Paulo, 2019.

Gráfico 14 - Índice de acertos dos participantes sobre responsabilidade exclusiva da enfermeira quanto ao acompanhamento da situação vacinal das crianças, questão 10. São Paulo, 2019.

Gráfico 15 - Índice de acertos dos participantes sobre 58 crença dos pais ou responsáveis quanto a não importância da vacinação e consequente não vacinação das crianças, questão 11. São Paulo, 2019.

Gráfico 16 - Índice de acertos dos participantes sobre interferência em não receber as doses de reforço para o esquema vacinal, questão 12. São Paulo, 2019.

Gráfico 17 - Índice de acertos dos participantes sobre oportunidades perdidas de vacinação, questão 13. São Paulo, 2019. 
Gráfico 18 - Índice de acertos dos participantes sobre vacinação simultânea em crianças com vacina em atraso, questão 14. São Paulo, 2019.

Gráfico 19 - Índice de acertos dos participantes sobre a 62 importância do registro correto das vacinas aplicadas para o acompanhamento da situação vacinal, questão 15. São Paulo, 2019.

Gráfico 20 - Índice de acertos dos participantes sobre o 62 aumento do risco de transmissão de doenças imunopreveníveis associado a não vacinação de crianças, questão 16. São Paulo, 2019.

Gráfico 21 - Índice de acertos dos participantes sobre o 63 benefício às crianças com contraindicação a determinadas vacinas através da vacinação de crianças que podem ser vacinadas, questão 17. São Paulo, 2019.

Gráfico 22 - Índice de acertos dos participantes sobre a reintrodução de doenças imunopreveníveis associada à recusa da vacinação, questão 18. São Paulo, 2019.

Gráfico 23 - Índice de acertos dos participantes sobre a 65 associação da falta de acolhimento dos profissionais ao não cumprimento do calendário vacinal, questão 19. São Paulo, 2019.

Gráfico 24 - Índice de acertos dos participantes sobre a 66 associação de reações vacinais anteriores à vacinação futura, questão 20. São Paulo, 2019.

Gráfico 25 - Índice de acertos dos participantes sobre 67 crença quanto a não efetividade de proteção das vacinas e consequente não vacinação, questão 21. São Paulo, 2019. 
Gráfico 26 - Índice de acertos dos participantes sobre o controle de qualidade das vacinas aplicadas no SUS, questão 22. São Paulo, 2019.

Gráfico 27 - Índice de acertos dos participantes sobre o desenvolvimento de imunidade após vacinação, questão 23. São Paulo, 2019.

Gráfico 28 - Índice de acertos dos participantes nas 70 questões objetivas 3 a 23. São Paulo, 2019.

Gráfico 29 - Índice de acertos categoria ACS nas questões objetivas 3 a 23. São Paulo, 2019.

Gráfico 30 - Índice de acertos categoria Auxiliar nas questões objetivas 3 a 23. São Paulo, 2019.

Gráfico 31 - Índice de acertos categoria Enfermeiro nas questões objetivas 3 a 23. São Paulo, 2019. 


\section{LISTA DE TABELAS}

Tabela 1 - Situações em que o profissional orienta os 50 responsáveis a deixar de vacinar a criança, questão 1. São Paulo, 2019.

Tabela 2 - Situações em que o profissional orienta os 51 responsáveis a adiar a vacinação da criança, questão 2. São Paulo, 2019.

Tabela 3 - Número de acertos, relação da vacina com a 70 doença contra a qual protege, questão 24. São Paulo, 2019.

Tabela 4 - Média, mínima e medidas de tendência centrais, 71 em relação aos acertos dos participantes nas questões objetivas, questões 3 a 23. 


\section{LISTA DE QUADROS}

Quadro 1 - Calendário vacinal para crianças com até 6 anos de idade. São Paulo, 2018

Quadro 2 - Motivos que levam à realização ou não da vacinação. São Paulo, 2019. São Paulo, 2019. 


\section{SUMÁRIO}

1 INTRODUÇÃO

1.1 VACINAS: O INÍCIO DAS AÇÕES DE VACINAÇÃO NO CONTEXTO

INTERNACIONAL E O PROGRAMA NACIONAL DE IMUNIZAÇÕES (PNI) ……............... 18

1.2 CALENDÁRIO VACINAL E AS DOENÇAS IMUNOPREVENÍVEIS ............................ 22

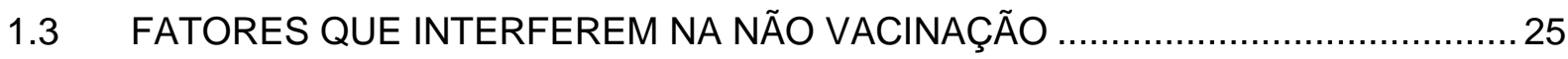

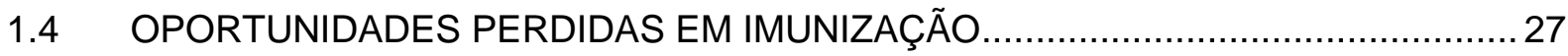

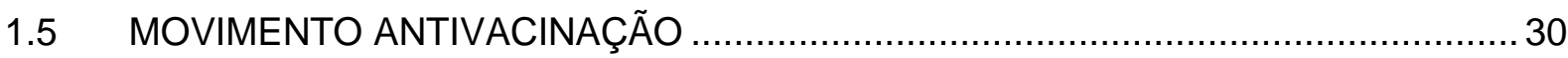

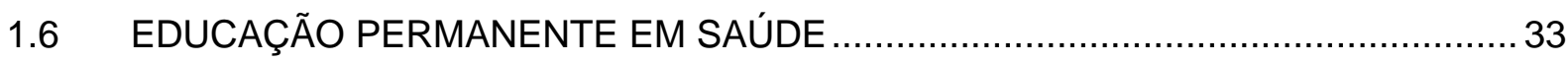

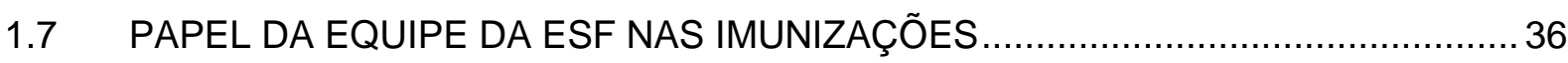

2 OBJETIVO

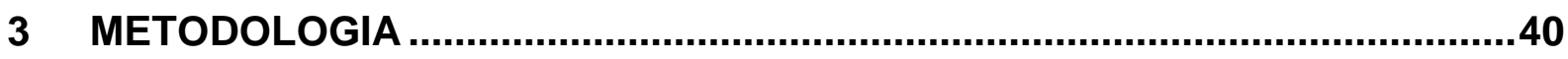

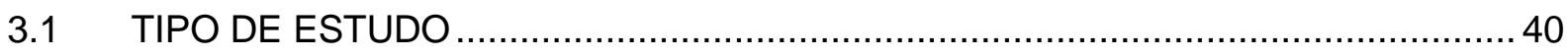

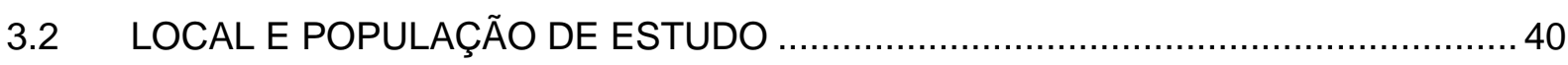

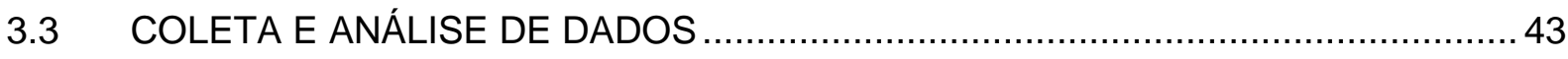

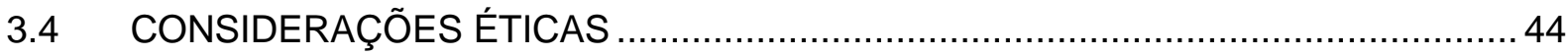

4 RESULTADOS

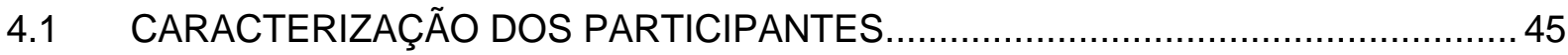

4.2 CONHECIMENTO DOS SUJEITOS E AVALIAÇÃO DA APRENDIZAGEM...............50

5 DISCUSSÃO

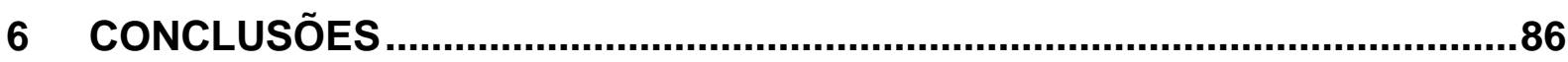

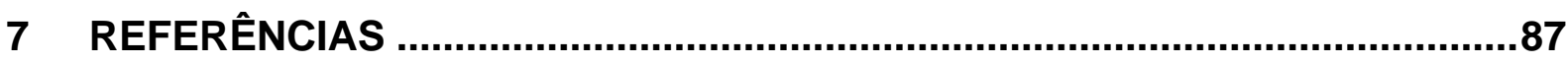

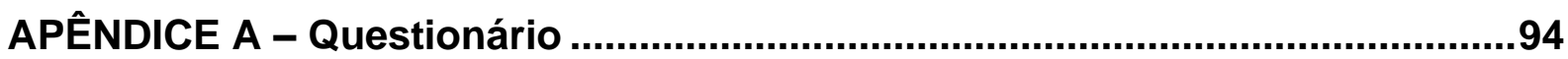

APÊNDICE B - Parecer consubstanciado CEP ...............................................99

APÊNDICE C - Termo de Consentimento Livre e Esclarecido..........................102 



\section{INTRODUÇÃO}

A Imunização é um dos campos de atuação da Enfermagem na Atenção Primária no Sistema Único de Saúde (SUS). Sua importância está diretamente ligada ao controle de doenças infectocontagiosas, o que, por sua vez, tem repercussão acentuada no perfil epidemiológico da população adscrita a uma Unidade Básica de Saúde (UBS), com diminuição na incidência das doenças imunopreveníveis.

Para que suas ações sejam bem-sucedidas, há uma série de fatores que precisam ser considerados, tais como, a formação dos profissionais de saúde diretamente envolvidos na prática da vacinação em geral e, mais especificamente, os profissionais da área de enfermagem, além dos demais profissionais que se relacionam com os usuários em algum momento na UBS, e dos demais setores sociais da comunidade, com destaque para o setor da educação, e a própria população-alvo destas ações. Além disso, as instituições governamentais e a mídia são importantes para o bom funcionamento e a divulgação do Programa Nacional de Imunizações (PNI).

A execução das atividades do PNI não deve ser restrita a um setor isolado na UBS. Antes, precisa estar inserida e ser lembrada em todas as demais práticas realizadas na unidade de saúde. Assim, os momentos de encontro com o usuário, nas visitas domiciliárias, nas consultas médicas e de enfermagem, no acolhimento, nos grupos educativos, no atendimento odontológico, entre outros, devem ser vistos como oportunidades para conferir a situação vacinal dos usuários e incentivar a adesão à prática de vacinação.

Moraes et al. (2003) dizem que quanto melhor estruturada estiver a rede de atenção primária à saúde, maior será o acesso e a adesão às atividades relacionadas à imunização no setor público.

Identificar os obstáculos que dificultam o acesso à vacinação é o primeiro passo para planejar ações sobre os fatores que contribuem para o atraso ou a não realização das vacinações preconizadas no PNI. 


\subsection{VACINAS: O INÍCIO DAS AÇÕES DE VACINAÇÃO NO CONTEXTO INTERNACIONAL E O PROGRAMA NACIONAL DE IMUNIZAÇÕES (PNI)}

Plotkin (2005) relata que o conceito de vacinação se originou, provavelmente, das crenças da homeopatia, em que pequenas doses de doença protegem contra doenças graves. Refere que o registro de aspiração de crostas da varíola, por via nasal, com a finalidade de imunização contra a doença na China, está datado no século XI, porém, o relato escrito só esteve disponível após o século XVII. Também refere registros de inoculações do material da pústula de um indivíduo doente em um indivíduo ainda sadio, na Índia, na mesma época. Dessas regiões, a variolação cutânea passou a ser praticada no Oriente Médio e na África, depois na Turquia e na Grã-Bretanha e, por fim, em outras regiões da Europa (Plotkin, 2005).

Edward Jenner observou que o contato do ser humano com a varíola bovina, através da ordenha de vacas, fazia desenvolver uma doença que também se apresentava com a formação de pústulas, porém, não fatal e que o imunizava contra a varíola humana. Assim, em 1796, realizou a primeira inoculação de material da pústula de uma pessoa que apresentava a varíola bovina em uma criança sadia, o que a deixou imunizada contra a varíola humana. Posteriormente, o material das pústulas das vacas doentes passou a ser inoculado em humanos, conferindo a estes a imunidade contra a doença (Plotkin, 2005).

Em 1881, Louis Pasteur fez um experimento com frangos, inoculando uma cultura de cólera aviária criada em laboratório, o que gerou a imunidade destes contra a doença. Como resultado disto, Pasteur construiu a hipótese de que patógenos podem ser atenuados através da exposição a condições específicas, para então serem utilizados na imunização do ser humano (Plotkin, 2005).

Em 1959, a OMS adotou uma Resolução que visava a erradicação mundial da varíola. O último caso registrado da doença, nas Américas, ocorreu em 1971, no Brasil e, no mundo, em 1977, na Somália. Em 1974, a OMS estabeleceu o Programa Ampliado de Imunização (PAI), em nível mundial e, em 1977, a Organização Panamericana de Saúde estabeleceu o Programa Ampliado de Imunização nas Américas (Andrus et al., 2017).

Em maio de 2011, na 64 assembleia Mundial de Saúde, foi proposto o Decênio de Vacinas (2011-2020) e um plano global de ações sobre imunização. O 
objetivo era alcançar um mundo onde todas as pessoas pudessem ter uma vida livre de doenças imunopreveníveis, independentemente do local onde vivem. Este plano de ação mundial sobre vacinas baseia-se nos progressos alcançados em saúde, como a diminuição do número de mortes em menores de 5 anos, que passou de 9,6 milhões, em 2000, para 7,6 milhões, em 2010. A diminuição da mortalidade está associada, entre outros fatores, ao aumento da cobertura vacinal e à inserção de novas vacinas (Organización Mundial de la Salud, 2012).

Para se alcançar o objetivo geral do Decênio de Vacinas foram estipulados seis objetivos estratégicos, que são:

1. Todos os países se comprometem com a imunização como uma prioridade.

2. Indivíduos e comunidades entendem o valor das vacinas e exigem a imunização como um direito e uma responsabilidade.

3. Os benefícios da imunização são distribuídos equitativamente a todas as pessoas.

4. Sistemas robustos de imunização são parte integrante de um sistema de saúde que funciona bem.

5. Programas de imunização que têm acesso sustentável a financiamento previsível, fornecimento de qualidade e tecnologias inovadoras.

6. Inovações em pesquisa e desenvolvimento nos níveis nacional, regional e global para maximizar os benefícios da imunização (Organización Mundial de la Salud, 2012).

No Brasil, o Programa Nacional de Imunizações (PNI) foi criado em 18 de setembro de 1973, com o objetivo de erradicar ou manter sob controle as doenças transmissíveis como a poliomielite, o sarampo, a tuberculose, a difteria, o tétano, a coqueluche e a varíola, seguindo o princípio da universalidade, uma vez que o acesso às ações de imunização é oferecido a toda a população, sem distinção.

As competências do Programa foram estabelecidas pelo Decreto $\mathrm{n}^{\circ}$ 78.231, de 12 de agosto de 1976, e permanecem válidas até a atualidade:

- implantar e implementar as ações relacionadas com as vacinações de caráter obrigatório;

- estabelecer critérios e prestar apoio técnico a elaboração, implantação e implementação dos programas de vacinação a cargo das secretarias de saúde das unidades federadas;

- estabelecer normas básicas para a execução das vacinações;

- supervisionar, controlar e avaliar a execução das vacinações no território nacional, principalmente o desempenho dos órgãos das secretarias de saúde, encarregados dos programas de vacinação; 
- centralizar, analisar e divulgar as informações referentes ao PNI (Brasil, 2003).

O Programa foi institucionalizado após o final da Campanha de Erradicação da Varíola, sob a coordenação da Divisão Nacional de Epidemiologia e Estatística de Saúde e, atualmente, é dirigido pela Coordenação Geral do Programa Nacional de Imunizações, inserido na Secretaria de Vigilância em Saúde do Ministério da Saúde. $\mathrm{Na}$ sua criação era centralizado e controlado exclusivamente pelo Ministério da Saúde, mas em sua trajetória, adquiriu uma característica mais descentralizada, com aumento da participação estadual e municipal (Brasil, 2003).

Um dos grandes marcos do PNI foi a erradicação de casos autóctones de poliovírus selvagem, certificada, em 1994, pela Organização Mundial da Saúde (OMS), através das ações de vigilância epidemiológica e altas coberturas vacinais. Outro marco bem-sucedido do Programa foi a rápida diminuição de casos de sarampo, exemplificada pelo registro, em 1990, de 45.778 casos e, em 1992, após a campanha de vacinação nacional, de 3.234 casos. O Brasil havia recebido certificado de erradicação do Sarampo pela Organização Panamericana de Saúde (OPAS), em 2016, porém o surto da doença no ano de 2019, em que, até a Semana Epidemiológica 39, já foram confirmados 6.640 casos da doença, sendo 5.652 por critério laboratorial e 988 por critério clínico epidemiológico. em 19 estados do país, sendo estes São Paulo, Rio de Janeiro, Maranhão, Santa Catarina, Mato Grosso do Sul, Minas Gerais, Pernambuco, Paraná, Distrito Federal, Espírito Santo, Piauí, Goiás, Rio Grande do Norte, Bahia, Sergipe, Rio Grande do Sul, Pará, Ceará, e Paraíba, evidencia a necessidade de vigilância contínua para este agravo. (Brasil, 2019)

Seguindo o princípio da equidade, foram implantados os Centros de Referência para Imunobiológicos Especiais (CRIES), que disponibilizam imunobiológicos especiais para a população que necessita, mediante prescrição médica, de imunização específica ou substituição de produtos disponíveis na rede básica.

As campanhas nacionais de imunização foram iniciadas em 1980, com a intensificação da vacinação contra a poliomielite e, até hoje, têm a função de atingir resultados rápidos para o controle de determinadas doenças imunopreveníveis. Porém, precisam ser vistas como uma ação excepcional, priorizando-se sempre a vacinação de rotina no cotidiano da sala de vacina (Brasil, 2003). 
O PNI está na agenda de prioridades do Ministério da Saúde, o que é comprovado pela ampliação constante do calendário vacinal. Atualmente, é caracterizado por descentralização/municipalização da execução, porém, permanece a verticalização da norma técnica. A municipalização é fator determinante para o sucesso do Programa, uma vez que as ações são adaptadas à realidade de cada município e região.

O Programa é referência na Organização Panamericana de Saúde (OPAS) devido ao seu sucesso, em meio às características demográficas do Brasil e à heterogeneidade da sua população, porém percebe-se que a queda sucessiva de coberturas vacinais, de diversas vacinas, está colocando em risco a perspectiva progressiva de sucesso do programa, como é possível observar com a atual epidemia de Sarampo. 


\subsection{CALENDÁRIO VACINAL E AS DOENÇAS IMUNOPREVENÍVEIS}

O Calendário de Vacinação atual (2018) para crianças até 6 anos de idade no estado de São Paulo é composto por 14 vacinas, conforme quadro abaixo.

Quadro 1. Calendário vacinal para crianças com até 6 anos de idade. São Paulo, 2018.

\begin{tabular}{|c|c|}
\hline Idade & Vacina \\
\hline Ao nascer & BCG, Hepatite B \\
\hline 2 meses & (DTP-Hib-HB) PENTA, VIP, Rotavírus, Pneumo10 \\
\hline 3 meses & Meningo C \\
\hline 4 meses & (DT-Hib-HB) PENTA, VIP, Rotavírus, Pneumo10 \\
\hline 5 meses & (DTP-Hib-HB) PENTA, VIP \\
\hline 6 meses & Febre amarela \\
\hline 9 meses & SCR, Meningo C, Pneumo10 \\
\hline 12 meses & DTP, VOP, Hepatite A, SCR-Varicela (Tetraviral) \\
\hline 15 meses & DTP, VOP, Varicela \\
\hline 4 anos & Influenza \\
\hline $6 m$ a $<5$ anos & \\
\hline
\end{tabular}

Como resultado de ações efetivas de imunização, a varíola foi erradicada, no Brasil, em 1973, e a Poliomielite, em 1989, e a transmissão autóctone do sarampo, também foi interrompida. Doenças como a Difteria, a Coqueluche e o Tétano acidental apresentam grande declínio no decorrer das últimas décadas. As meningites causadas por Haemophilus Influenzae representavam a segunda causa mais frequente de meningite bacteriana até 1999. Após o ano 2000, com a introdução da vacina contra este agente, houve queda de $90 \%$ na incidência de meningites causadas pelo mesmo (Brasil, 2010).

$A$ vacina BCG é preparada com bacilos vivos e é indicada para prevenir formas graves de tuberculose (miliar e meníngea). É aplicada em dose única, ao nascer, sendo necessário peso mínimo de 2,000 kg para sua administração (Brasil, 2014).

A vacina da Hepatite $B$ previne a infeção pelo vírus da hepatite $B$. A primeira dose deve ser aplicada preferencialmente nas primeiras 24 horas de vida em recém- 
nascidos e a continuidade do esquema se dá com as três doses da vacina Pentavalente (Brasil, 2014).

A vacina Pentavalente protege contra a difteria, o tétano, a coqueluche, a hepatite B e infecções causadas pelo Haemophilus influenzae b. É aplicada aos dois, quatro e seis meses de vida, no esquema básico (Brasil, 2014).

A vacina DTP é indicada para aplicação como doses de reforço da vacina Pentavalente, aos 15 meses e aos 4 anos de idade (Brasil, 2014).

A Vacina Inativada contra a Poliomielite (VIP) contém os tipos 1, 2 e 3 inativados do vírus que causa a poliomielite. É aplicada aos dois, quatro e seis meses de vida, no esquema básico. (Brasil, 2014).

A Vacina Oral contra a Poliomielite (VOP) contém os tipos 1, 2 e 3 atenuados do vírus que causa a poliomielite. É aplicada aos 15 meses e aos 4 anos de idade, como reforço para as doses de VIP. São administradas duas gotas da vacina por via oral (Brasil, 2014).

A vacina Pneumocócica Conjugada 10 Valente é indicada para prevenir infecções invasivas (sepse, meningite, pneumonia e bacteremia) e otite média aguda, causada pelos sorotipos do vírus que contém em sua composição. É aplicada aos 2 e 4 meses de idade, no esquema básico, e um reforço aos 12 meses de idade (Brasil, 2014).

A vacina Rotavírus é indicada para a prevenção de gastroenterites causadas por rotavírus dos sorotipos $\mathrm{G} 1$, embora ofereça também proteção cruzada contra outros sorotipos de rotavírus. É administrada aos 2 e 4 meses de idade, sendo que a primeira dose só pode ser administrada até os 3 meses e 15 dias de idade e a segunda dose até os 7 meses e 29 dias. Caso a criança não receba a primeira dose até a idade limite, não deve receber nenhuma dose da vacina (Brasil, 2014).

A vacina Meningocócica $C$ é indicada para a prevenção da doença sistêmica causada pelo sorogrupo $\mathrm{C}$ da bactéria Neisseria meningitidis. É aplicada aos 3 e 5 meses no esquema básico, e um reforço aos 12 meses de idade (Brasil, 2014).

A vacina tríplice viral (SCR) é composta por vírus vivos atenuados do sarampo, da caxumba e da rubéola. É aplicada aos 12 meses de idade no esquema básico (Brasil, 2014).

A vacina contra a hepatite A é indicada para a prevenção da infecção pelo vírus da hepatite A. É aplicada em dose única aos 15 meses de idade (Brasil, 2014). 
A vacina Tetra Viral (SCR-Varicela) é composta por vírus vivo atenuado do sarampo, da caxumba, da rubéola e da varicela. É aplicada aos 15 meses de idade em crianças que tenham recebido a primeira dose de tríplice viral (Brasil, 2014).

A vacina contra a Influenza é composta por diferentes cepas do vírus Myxovirus influenzae inativados. A composição é definida ano após ano, em função dos dados epidemiológicos que apontam a cepa do vírus que está circulando predominantemente nos hemisférios Norte e Sul. É indicada para proteger contra o vírus da influenza e contra as complicações causadas pela doença. Para crianças de 6 meses a 2 anos de idade, são aplicadas 2 doses de $0,25 \mathrm{ml}$ da vacina, com intervalo de 30 dias. Para crianças de 3 a 8 anos de idade, são aplicadas 2 doses de 0,5ml, com intervalo de 30 dias. Crianças que já receberam a vacina Influenza no ano anterior recebem apenas uma dose, com o volume correspondente à faixa etária (Brasil, 2014).

A vacina contra a Febre Amarela é composta por vírus vivos atenuados da febre amarela. É indicada para prevenir esta doença em residentes ou viajantes que se deslocam para áreas com recomendação de vacinação, a partir de 9 meses de idade (Brasil, 2014). 


\subsection{FATORES QUE INTERFEREM NA NÃO VACINAÇÃO}

Andrade (2014) ressalta que o cumprimento do calendário vacinal é essencial frente às doenças imunopreveníveis, e que a não efetivação deste, pode ocasionar prejuízos significativos à saúde pública.

Yokokura et al. (2013) destacam que a vacinação é uma das medidas mais seguras para a prevenção de doenças transmissíveis e com a melhor relação custobenefício para o setor saúde, sendo que o acesso a esta ação, tem papel importante na redução da morbimortalidade infantil. Assim, taxas baixas e heterogêneas de cobertura vacinal podem causar a reintrodução de doenças já erradicadas. Estes autores reúnem dados de outras publicações e descrevem os principais fatores para a não vacinação: baixa renda, extremos de idade materna, maior número de filhos, baixa escolaridade materna, trabalho materno fora do lar, maior número de moradores no domicílio, residência há menos de um ano na área, falta de conhecimento acerca de doenças imunopreveníveis e presença de doença na criança. Em seu estudo, em São Luís, no Maranhão, estes mesmos autores associam menores taxas de cobertura vacinal às famílias com menor renda e piores indicadores socioeconômicos, crianças e pais de pele negra e crianças do sexo feminino, e conclui que a educação dos profissionais de saúde é uma estratégia eficaz para a melhor cobertura vacinal das crianças, assim como o incremento de políticas que diminuam as desigualdades sociais (Yokokura et. al, 2013).

Bujes (2012) realizou pesquisa bibliográfica sobre o motivo do atraso vacinal em crianças. Destaca que uma criança só pode ser considerada imunizada se tiver recebido todas as doses das vacinas, incluindo os reforços, e que a meta para a cobertura vacinal deveria ser o esquema completo, com a finalidade de se reduzir ao máximo a mortalidade infantil. Segundo esta autora, as doses iniciais das vacinas costumam ser realizadas, porém, os reforços ainda apresentam baixas coberturas. Esta autora relata que é responsabilidade da equipe de saúde buscar ativamente crianças faltosas e orientar os responsáveis para incentivar a vacinação, e realça a importância de se desenvolver atividades intersetoriais, por exemplo, com a escola, para que as crianças sejam multiplicadoras do tema em seu ambiente familiar. Destaca que a falta de registro, ou o registro com dados incorretos, no cartão-espelho de vacinação da criança, dificultam o acompanhamento da situação vacinal. A autora também aponta a importância da capacitação do profissional que atua na sala de 
vacina, destacando a quantidade de informações contidas neste tema (Bujes, 2012). Os fatores para o atraso vacinal, identificados em sua pesquisa, foram os mesmos apontados na pesquisa bibliográfica realizada por Yokokura et al. (2013), e ainda: a impossibilidade de leitura do cartão de vacina por mães analfabetas, a crença popular de que a vacinação básica não requer atenção, o medo das reações vacinais, crenças, superstições, mitos e credos religiosos, além de esquecimento das doses de reforço. Também aponta fatores relacionados às famílias das crianças e relacionados ao sistema de imunização, como a inacessibilidade dos vacinadores às residências, distanciamento cultural entre o cuidador e os profissionais de saúde, oportunidades perdidas nos serviços de saúde, dificuldade de acesso à UBS, falta de insumos para a vacinação e falta de informação fornecida no momento de aplicação das vacinas.

O estudo realizado por Andrade (2014) também teve como resultado que o trabalho das mães fora de casa, mãe com menores níveis de instrução escolar, falta de imunobiológicos, difícil acesso à UBS, falsas contraindicações à vacinação, são fatores associados ao atraso vacinal infantil. 


\subsection{OPORTUNIDADES PERDIDAS EM IMUNIZAÇÃO}

Bellesi (2007) afirma que a vacinação é um "recurso para a vida plena", no sentido de possibilitar maior nível de saúde disponível ao "prevenir doenças infecciosas e até degenerativas". Relata que milhões de pessoas ao redor do mundo morrem por doenças que poderiam ser evitadas pelo acesso à vacinação, e que desperdiçar oportunidades de vacinar ou contraindicar vacinações é uma das causas da diminuição do acesso. Segundo este autor, oportunidade perdida em imunização é definida como: "circunstância na qual uma pessoa, ao visitar um serviço de saúde, deixa de ter sua situação vacinal considerada, seja para efeito de atualização, encaminhamento, esclarecimento, indicação ou aplicação em ocasião oportuna" (Bellesi, 2007). Sendo assim, quando a situação vacinal não é verificada e, se necessário, atualizada, no comparecimento do usuário ao serviço de saúde por motivos diversos, ou quando o usuário recebe uma falsa contraindicação à vacinação pelo profissional de saúde, ou quando o profissional realiza apenas uma e não todas as vacinas que deveriam ser atualizadas no momento da vacinação, estão ocorrendo oportunidades perdidas em imunização.

Paulo (2010) cita o "Global review of missed opportunities for immunization", realizado pela Organização Mundial de Saúde, em 1993, e define oportunidade perdida como a não realização de todas as vacinas necessárias em um indivíduo que procura um serviço de saúde e, ainda, quando precisa de atualização vacinal e não apresenta nenhuma contraindicação real às vacinas. A autora apresenta as reais contraindicações às vacinas de bactérias atenuadas ou de vírus vivo atenuado, que são: reação anafilática à dose anterior da vacina ou a algum de seus componentes, gestantes e pessoas com imunodeficiência congênita ou adquirida e idosos com doenças crônicas. Também destaca as situações em que se recomenda o adiamento da vacinação: até três meses após o tratamento com imunossupressores ou corticoides em dose elevada, administração de imunoglobulina, sangue ou derivados, ou durante a evolução de doenças agudas febris graves (Paulo, 2010).

Paulo (2010) também menciona as razões pelas quais há perda de oportunidade de imunização e, dentre elas, estão: a resistência na administração simultânea de vacinas por parte do profissional ou dos pais; as falsas contraindicações às vacinas; atitudes negativas dos profissionais de saúde; problemas logísticos e recusa do paciente ou de familiares. 
Esta autora ressalta a importância da vacinação em crianças, pois seu sistema imune ainda é frágil, ressaltando que esta prática estimula o amadurecimento imunológico. Também observa que é necessário o início da imunização ainda nos primeiros dias de vida, objetivando a proteção contra doenças transmissíveis imunopreveníveis, o mais precocemente possível (Paulo, 2010).

Em sua pesquisa bibliográfica, Bujes (2012) levanta aspectos estruturais dos serviços de saúde, que colaboram com as oportunidades perdidas em imunização, tais como atraso no agendamento de consultas, horário de funcionamento da unidade durante o dia e durante a semana, falta de distração para as crianças nas salas de espera, falta de pessoal, insumos e vacinas.

As falsas contraindicações à vacinação são fatores importantes que geram oportunidades perdidas em imunização. Paulo (2010) destaca as mais frequentes, descritas abaixo:

- doenças comuns, como distúrbios do trato respiratório superior com tosse e/ou coriza; diarreia e/ou vômito; afecções da pele;

- história pregressa da doença imunoprevenível contra a qual seria vacinada;

- desnutrição;

- uso de antimicrobiano;

- vacinação contra a raiva;

- distúrbio neurológico estável;

- história familiar de convulsão;

- uso sistêmico de corticosteroides nas seguintes situações: curta duração (inferior a duas semanas), em qualquer dose; doses baixas ou moderadas, por qualquer duração; tratamento prolongado, em dias alternados, com corticosteroides de ação curta; doses de manutenção fisiológica;

- alergias, de caráter não anafilático, relacionadas aos componentes das vacinas;

- reação dermatológica ao timerosal;

- prematuridade ou baixo peso ao nascer - em relação ao adiamento das vacinas (exceto BCG, que exige mínimo de $2.000 \mathrm{~g}$ para a aplicação); 
- internação hospitalar.

Andrade (2014) ressalta que o profissional de saúde é responsável por compartilhar conhecimentos sobre imunizações com os pais ou responsáveis pelas crianças. Para evitar que tanto os profissionais que atuam nas salas de vacina, como os que atuam na orientação dos responsáveis sobre a imunização das crianças, contraindiquem a vacinação em situações falsas, se faz necessário investir na capacitação e atualização destes profissionais quanto às situações que exigem contraindicações reais na vacinação. 


\subsection{MOVIMENTO ANTIVACINAÇÃO}

Segundo Vasconcellos-Silva (2015), estatísticas oficiais têm identificado pais que não vacinam seus filhos devido a "crenças filosóficas" ou pelo temor de riscos de efeitos colaterais, e até mesmo pelo desenvolvimento da doença que se quer prevenir.

Este autor relata que, em 1853, na Inglaterra, a vacinação se tornou compulsória, o que causou uma reação negativa de pais que organizaram movimentos em defesa da liberdade. A não adesão desses grupos à vacinação trouxe à região aumento da mortalidade por doenças transmissíveis não observadas em territórios que aderiram de forma mais homogênea à imunização (Vasconcellos-Silva, 2015).

Em 1904, o Rio de Janeiro sofreu uma importante epidemia de varíola. Oswaldo Cruz era o diretor geral de saúde pública, e enviou ao Congresso uma lei sobre a vacinação obrigatória que, apesar de ter sido instituída em 1837, nunca havia sido efetivada. Foram criadas brigadas sanitárias que entravam nas casas e vacinavam as pessoas à força. A forma autoritária como esta campanha foi conduzida, e o pouco conhecimento da população sobre vacinas e seus efeitos sobre o corpo, levaram a uma rejeição por uma grande parte da população, que ocasionou a chamada "Revolta da Vacina", em 11 de novembro do mesmo ano. O movimento foi marcado por embates entre a massa da população envolvida e a polícia, que culminaram em mortos, feridos e presos (Porto, 2003).

O livro "Recusa de vacinas: causas e consequências", promovido pela Sociedade Brasileira de Imunizações, traz alguns fatores que consideramos oportuno destacar (Levi, 2013). Argumentos religiosos são utilizados mesmo antes da existência da "vacina de Jenner". Argumentava-se que as doenças são enviadas por Deus para punir os pecadores, e que não se devia modificar o desejo de Deus através da vacinação. Porém, atualmente, os movimentos antivacinacionistas perderam muito de sua base religiosa, e são raros os grupos que fazem objeção à vacinação com esses argumentos (Levi, 2013).

Levi (2013) ressalta a controvérsia de possivelmente maior impacto em relação à imunização. Wakefield publicou estudo com pequeno número de crianças propondo associação da vacina SCR e autismo. Este estudo, publicado pela revista Lancet, em 1998, recebeu várias críticas quanto a sua metodologia, dado que o estudo não era controlado, tinha pequena amostra (12 crianças) e inconsistências nos 
resultados. Além disso, foi descoberto que seu autor havia recebido pagamento de advogados em processos por compensação de danos vacinais. Em 2004, foi instalado julgamento contra o mesmo e, somente em 2010, foi emitido o veredicto de culpabilidade por conduta profissional errônea grave, quando o registro profissional de Wakefield foi cassado. No mesmo ano, a revista Lancet cancelou o estudo dos arquivos de sua publicação (Levi, 2013). Posteriormente, estudos realizados no Reino Unido, América do Norte e Ásia, não encontraram nenhuma associação entre o autismo e a vacina SCR (Levi, 2013).

Também foi levantada correlação entre a vacina SCR e autismo devido ao uso do timerosal. Porém, esta hipótese também foi negada em outros estudos populacionais. Estudos realizados nos Estados Unidos também verificaram que o composto, que pode ser neurotóxico em altas doses, é o metilmercúrio, porém, o timerosal contém o etilmercúrio, que não foi associado a esse evento (Levi, 2013).

$\mathrm{Na}$ década de 1990, teve origem na França uma teoria que associava a vacina contra a Hepatite $B$ à esclerose múltipla, o que gerou grande alarme na mídia. Esta hipótese também foi negada em estudos populacionais (Levi, 2013).

Apesar de refutadas as associações relacionadas acima, ainda são aceitas por parcelas da sociedade, principalmente entre as classes sociais mais altas. Estudo desenvolvido por Vasconcellos-Silva (2015), a esse respeito, demonstra que as crianças não imunizadas eram predominantemente do sexo masculino, filhos de mães casadas, com alto nível de escolaridade, com renda acima da média nacional e amplo acesso a meios de comunicação de massa. A distribuição geoeconômica dessas famílias, em geral, se configurava em agrupamentos de vizinhanças, o que tenderia a aumentar o risco de transmissão. Este autor também aponta que a adesão de celebridades à causa antivacinacionista, e sua divulgação pela mídia, colabora para a ampliação do movimento (Vasconcellos-Silva, 2015).

Em abril de 1955, logo após a liberação da vacina contra a poliomielite, desenvolvida por Salk, foram registrados, nos Estados Unidos, cerca de 200 casos de paralisia associados à poliomielite. Investigações revelaram que esses casos decorreram do processo de inativação ineficaz do vírus da poliomielite na vacina produzida pelo laboratório Cutter. Entretanto, vacinas produzidas por outros grandes laboratórios não continham a mesma falha de produção. Após este evento, a regulamentação para a produção e distribuição de vacinas se tornou muito mais 
rigorosa e eficaz, o que leva a um alto registro de segurança nas vacinas que são comercializadas pelos laboratórios (Fitzpatrick, 2006).

É importante ressaltar que os movimentos antivacinação já existem no Brasil, e que o esclarecimento dos profissionais de saúde e da população se torna cada vez mais necessário para que se mantenham níveis adequados de cobertura vacinal. Para tanto, faz-se necessária a prática da educação permanente em saúde, que pode contribuir para a transformação das ações relacionadas à vacinação na Atenção Primária em Saúde (APS). 


\subsection{EDUCAÇÃO PERMANENTE EM SAÚDE}

No anexo II da Política Nacional de Educação Permanente em Saúde (Brasil, 2009b), define-se que:

"A Educação Permanente é aprendizagem no trabalho, onde o aprender e o
ensinar se incorporam ao cotidiano das organizações e ao trabalho. A
educação permanente se baseia na aprendizagem significativa e na
possibilidade de transformar as práticas profissionais. A educação
permanente pode ser entendida como aprendizagem-trabalho, ou seja, ela
acontece no cotidiano das pessoas e das organizações. Ela é feita a partir
dos problemas enfrentados na realidade e leva em consideração os
conhecimentos e as experiências que as pessoas já têm."

Maria Cristina Davini, autora do terceiro capítulo da Política Nacional de Educação Permanente em Saúde, cita que a capacitação é uma das estratégias mais usadas no enfrentamento de problemas nos serviços de saúde e que visa fortalecer conhecimentos, atitudes e práticas. Porém, ressalta que esta estratégia não é suficiente para a mudança institucional, pois visa apenas a mudanças pontuais em determinados processos, não buscando uma transformação dos conceitos no contexto em que ocorrem os problemas. Sendo assim, esta autora traz à tona a importância da educação permanente, uma vez que requer uma análise estratégica do problema e da cultura organizacional onde se coloca, para então elaborar, planejar e executar ações (Brasil, 2009b).

A autora traz uma crítica ao modelo escolar, muito presente nas capacitações, em que o principal objetivo é atualizar conceitos e práticas através da transmissão de conhecimentos que, posteriormente, deveriam ser levados à prática. Porém, dada a não aproximação dos sujeitos à análise do problema, muitas vezes o conhecimento transmitido não chega a ser posto em prática. A Educação Continuada é considerada pela autora como uma continuidade do modelo escolar, em que existe distanciamento entre a prática e o saber. Nesse modelo, o conhecimento acadêmico inibe o conhecimento adquirido no trabalho.

A Educação Permanente, por sua vez, incorpora o ensino e o aprendizado às práticas laborais, partindo da problematização do fazer e reconhecendo os trabalhadores como atores reflexivos da prática e construtores de conhecimento. Este modelo "enxerga" o potencial educativo da prática do trabalho (Brasil, 2009b).

Cardoso (2012) também destaca a educação permanente como "elemento transformador dos sujeitos", que passam a reconhecer em si a capacidade de pensar 
criticamente sobre sua realidade, para então agir sobre ela. Ressalta que, desta forma, é possível analisar o cotidiano de trabalho em relação às tecnologias utilizadas, à eficácia do serviço produzido, ao acolhimento ao usuário e às relações estabelecidas na interação social. Salienta que a aprendizagem passa a ser significativa quando a nova informação estabelece vínculo com conceitos já relevantes na estrutura cognitiva do aprendiz.

Silva e Peduzzi (2011) citam que o trabalho e educação são práticas sociais e, assim sendo, devem interagir no processo de transformação um do outro. Ressaltam que o trabalho em saúde é parte da produção de serviços, de modo que seu produto não é material, mas sim, processos interativos entre os trabalhadores e os usuários dos serviços de saúde, em que a produção e o consumo se dão continuamente. As autoras acrescentam que o processo de trabalho em saúde pode ser dividido em dois aspectos básicos, sendo um deles, a dimensão técnico-científica e o outro, a dimensão da interação social. Desta forma, o conhecimento técnicocientífico é o instrumento em que as ações de saúde estão embasadas, o que traz segurança para a realização destas ações. Este conhecimento é sempre direcionado para determinado fim, que é o alcance das necessidades de saúde da população atendida. A interação social, por sua vez, diz respeito à ação comunicativa estabelecida entre os trabalhadores, gestores e usuários. Destacam que, para a efetividade da esfera educativa na saúde, devem ser consideradas estas duas dimensões.

Para o desenvolvimento do conhecimento técnico-científico se faz necessária a atualização constante dos conceitos e práticas desenvolvidos no trabalho, o que remete ao modelo de educação continuada, já apresentado. Porém, ao levar em conta os aspectos interativos do processo, é necessário utilizar-se das ferramentas da educação permanente (Silva, Peduzzi, 2011).

Utilizar-se da modalidade da educação permanente em saúde requer a compreensão dos trabalhadores como sujeitos ativos da construção do conhecimento, o que faz com que estes sejam estimulados a rever suas práticas, partindo do conhecimento já previamente adquirido, para a construção de novos saberes e ações e resolução de problemas. Esta abordagem educativa remete ao conceito de integralidade, proposto pelo SUS, uma vez que permite a captação ampliada das necessidades de saúde apresentadas (Silva, Peduzzi, 2011).

Peduzzi et al. (2009) destacam que nesse escopo da educação 
permanente em saúde, o trabalho é definido como "espaço de problematização, reflexão, diálogo e construção de consensos", que possibilita as mudanças em concordância ao conceito de integralidade. Ressaltam os três eixos de sentido da integralidade aplicados à educação permanente: a articulação das ações de prevenção, promoção e reabilitação da saúde; captação mais abrangente das necessidades de saúde; e, a organização dos serviços de saúde com a articulação dos diferentes níveis de complexidade do sistema de saúde e as ações interdisciplinares e intersetoriais.

Entende-se que a implantação de um processo educativo participativo com a equipe de saúde na UBS, que envolva a reflexão do seu processo de trabalho, mais especificamente, nas ações relacionadas à imunização, sua importância, papel de cada profissional e da equipe da Estratégia Saúde da Família (ESF), conhecimentos técnico-científicos necessários para a atuação neste setor, significado de oportunidades perdidas em imunização, momentos em que isto pode ocorrer na UBS e como minimizar sua ocorrência, são essenciais para o incremento da cobertura vacinal. 


\subsection{PAPEL DA EQUIPE DA ESF NAS IMUNIZAÇÕES}

Ramos et al. (2010) destacam que, em municípios com cobertura maior que $70 \%$ de equipes da ESF, crianças de 0 a 2 anos de idade possuem maior chance de receber atividades preventivas, com redução da mortalidade infantil. Dentre as ações direcionadas às crianças, está o acompanhamento adequado do cumprimento do calendário vacinal. Ressaltam que a ação dos agentes comunitários de saúde (ACS) em alertar as famílias sobre as próximas vacinas a serem recebidas pelas crianças, contribui positivamente para este resultado.

Estudo realizado por Guimarães, em 2009, também apontou redução da morbimortalidade por doenças imunopreveníveis com a implantação da ESF em Olinda, e Luhm (2010) mostrou que, aos 24 meses, a cobertura vacinal era maior em crianças cadastradas em unidades com ESF. Tauil (2017) destaca que crianças atendidas por equipes da ESF têm melhores coberturas vacinais, ressaltando o trabalho dos agentes comunitários de saúde na rotina mensal de verificação das carteiras vacinais, e busca ativa de faltosos nas visitas domiciliares.

Henrique (2010) salienta que a atuação em saúde, no modelo da ESF, requer trabalho em equipe, territorializado, baseado, entre outras ações, na promoção à saúde. Destaca que o diagnóstico comunitário é uma "fotografia da realidade local" de uma população e que utilizar este instrumento para o levantamento dos recursos disponíveis de uma comunidade, questões políticas, culturais e sociais, intrínsecas ao território, auxilia na superação das dificuldades de monitoramento e avaliação do processo saúde-doença desta população.

O Manual Técnico/Auxiliar de Enfermagem da Prefeitura de São Paulo ressalta a importância da equipe de Atenção Básica, em particular a equipe de enfermagem, em sensibilizar a população para a maior compreensão dos benefícios das vacinas e manter a atualização vacinal, com a busca ativa de faltosos, ação que deve integrar toda a equipe (São Paulo, 2012).

Barros (2012) evidencia a importância da educação continuada dos profissionais que atuam na sala de vacina, a fim de evitar falsas contraindicações à vacinação, o que também aponta Ferreira (2017), que acrescenta que a falta de capacitação dos profissionais se torna uma barreira de acesso à vacinação. Esses profissionais precisam estar aptos a instruir adequadamente pais e responsáveis das crianças sobre imunizações. Esta última autora realça a importância do acolhimento 
no momento do atendimento na sala de vacina, buscando o estabelecimento de vínculos, o que proporcionaria melhora da adesão.

Ferreira (2017) ainda salienta que é fundamental que o enfermeiro desenvolva seu papel como supervisor das atividades na sala de vacina, identificando e corrigindo eventuais falhas nos processos de trabalho. Costa (2015) também aponta que o enfermeiro responsável por imunização na UBS precisa ter conhecimento adequado sobre imunobiológicos, eventos adversos pós-imunização e contraindicações à vacinação, a fim de coordenar de maneira eficaz as ações relacionadas à imunização. Oliveira (2016) destaca que esse profissional também é responsável pela educação permanente dos demais profissionais envolvidos nas atividades relacionadas à imunização.

Em estudo com enfermeiros e médicos da ESF, realizado no Nordeste, Souza et al. (2018) apontaram que apenas 7,2\% dos profissionais conheciam adequadamente os motivos para o adiamento de vacinas no primeiro ano de vida, e $13,3 \%$ dos sujeitos da pesquisa responderam corretamente as questões sobre os motivos de contraindicação permanente à vacinação, apontando para a falta de educação permanente para esses profissionais.

A cartilha "O trabalho do Agente Comunitário de Saúde" (Brasil, 2009a) orienta que este profissional deve identificar os fatores socioeconômicos, culturais e ambientais que interferem na saúde das famílias de seu território. E descreve algumas atribuições destes profissionais, dentre elas:

a. Identificar áreas e situações de risco individual e coletivo;

b. Encaminhar as pessoas aos serviços de saúde, sempre que necessário;

c. Orientar as pessoas, de acordo com as instruções da equipe de saúde;

d. Acompanhar a situação de saúde das pessoas, para ajudá-las a conseguir bons resultados (Brasil, 2009a).

Destaca, também, que o enfoque educativo é um elemento fundamental na qualidade da atenção prestada em saúde, e que o processo de educar está em construção permanente. Estas ações devem estar presentes no cotidiano das visitas domiciliárias desenvolvidas pelos ACS (Brasil, 2009a).

Pinto e Fracolli (2010) ressaltam que o processo de capacitação e educação do ACS precisa ser considerado, a fim de transformar esses profissionais em sujeitos proativos em sua atuação. Este processo deve priorizar as necessidades 
destes profissionais e da comunidade, através da "construção de um projeto de educação para ensinar a ensinar".

O presente estudo propõe uma reflexão sobre as ações relacionadas à imunização na APS, com foco na atuação da equipe de enfermagem e do ACS como integrantes da equipe da ESF. Para garantir a imunização como proposta pelo PNI, e evitar a oportunidade perdida em imunização, é preciso que tanto os profissionais que atuam diretamente na sala de vacina, como os que atuam na orientação da população sobre vacinação, estejam adequadamente informados sobre as verdadeiras e falsas contraindicações à vacinação. 


\section{OBJETIVO GERAL}

Identificar o conhecimento da equipe de enfermagem e dos agentes comunitários de saúde a respeito de imunizações, em uma UBS na Região Sul do município de São Paulo.

\subsection{OBJETIVO ESPECÍFICO}

Analisar os resultados das avaliações de aprendizagem na ação educativa realizada com os profissionais; 


\section{METODOLOGIA}

\subsection{TIPO DE ESTUDO}

Estudo com abordagem quantitativa do tipo descritivo-exploratório, com desenho pré e pós-exposição, em amostra de conveniência.

\subsection{LOCAL E POPULAÇÃO DE ESTUDO}

Segundo os Indicadores para Diagnóstico Sintético da Saúde da Cidade de São Paulo, este município tem 11.753.659 habitantes em uma área de 1.509 km². Para fins administrativos, o Município está subdividido em 6 Coordenadorias Regionais de Saúde, às quais se vinculam as 27 Supervisões Técnicas de Saúde (Figura 3.1). Segundo o Boletim CEInfo de junho/2018, a cobertura populacional estimada de equipes da ESF e Equipes de Atenção Básica, no município, é de 63,3\%. No Portal da Prefeitura da Cidade de São Paulo, aponta-se que, atualmente, há um total de 460 UBS no Município, destas, 293 com ESF (São Paulo, 2013, 2018, 2019).

A Região Sul é a mais populosa do Município, contando com 2.755.537 habitantes, em uma área de $654,70 \mathrm{~km}^{2}$. Segundo o Boletim CElnfo de junho/2018, a cobertura populacional estimada de equipes da ESF e Equipes de Atenção Básica, na Região Sul, é de 83,7\%. No Portal da Prefeitura da Cidade de São Paulo, aponta-se que, atualmente, há um total de 124 UBS na Região, destas, 105 com ESF (Figura 3.2) (São Paulo, 2018, 2019). 
Figura 1. Supervisões Técnicas de Saúde do Município de São Paulo. São Paulo, 2019.

COORDENADORIA REGIONAL DE SAÚDE E SUPERVISÃO TÉCNICA DE SAÚDE MUNICÍPIO DE SÃO PAULO

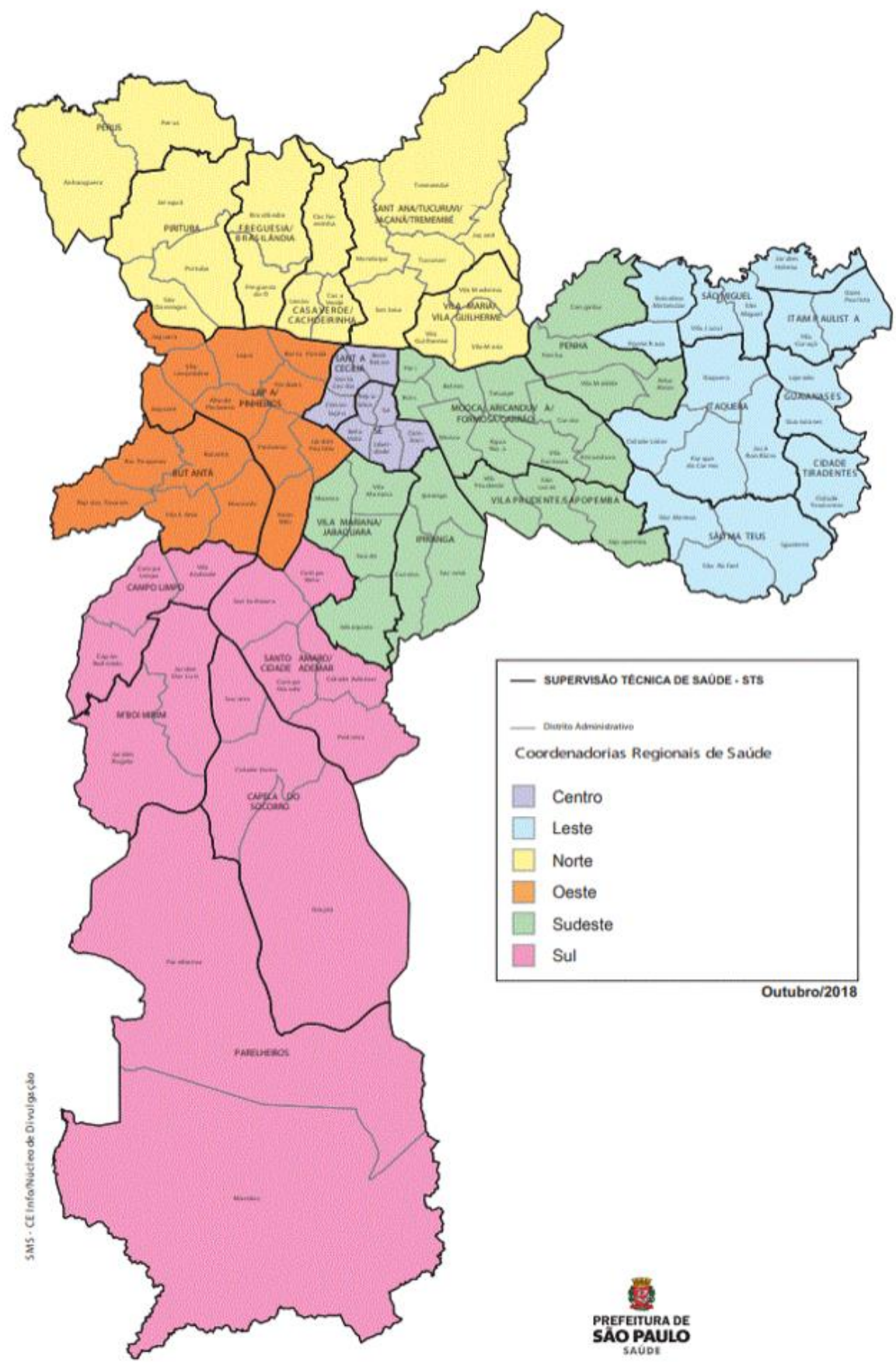

Fonte: São Paulo, Secretaria Municipal de Saúde, Coordenação de Epidemiologia e Informação (CEInfo). Relação dos Estabelecimentos/Serviços da Secretaria Municipal de Saúde por Coordenadoria Regional de Saúde e Supervisão Técnica de Saúde [Internet]. São Paulo; 2018. Disponível em: https://www.prefeitura.sp.gov.br/cidade/secretarias/upload/saude/arquivos/organizacao/Unid_Munic_S aude_Super.pdf 
Figura 2. Estabelecimentos de Saúde da Coordenadoria Regional de Saúde Sul. São Paulo, 2019.
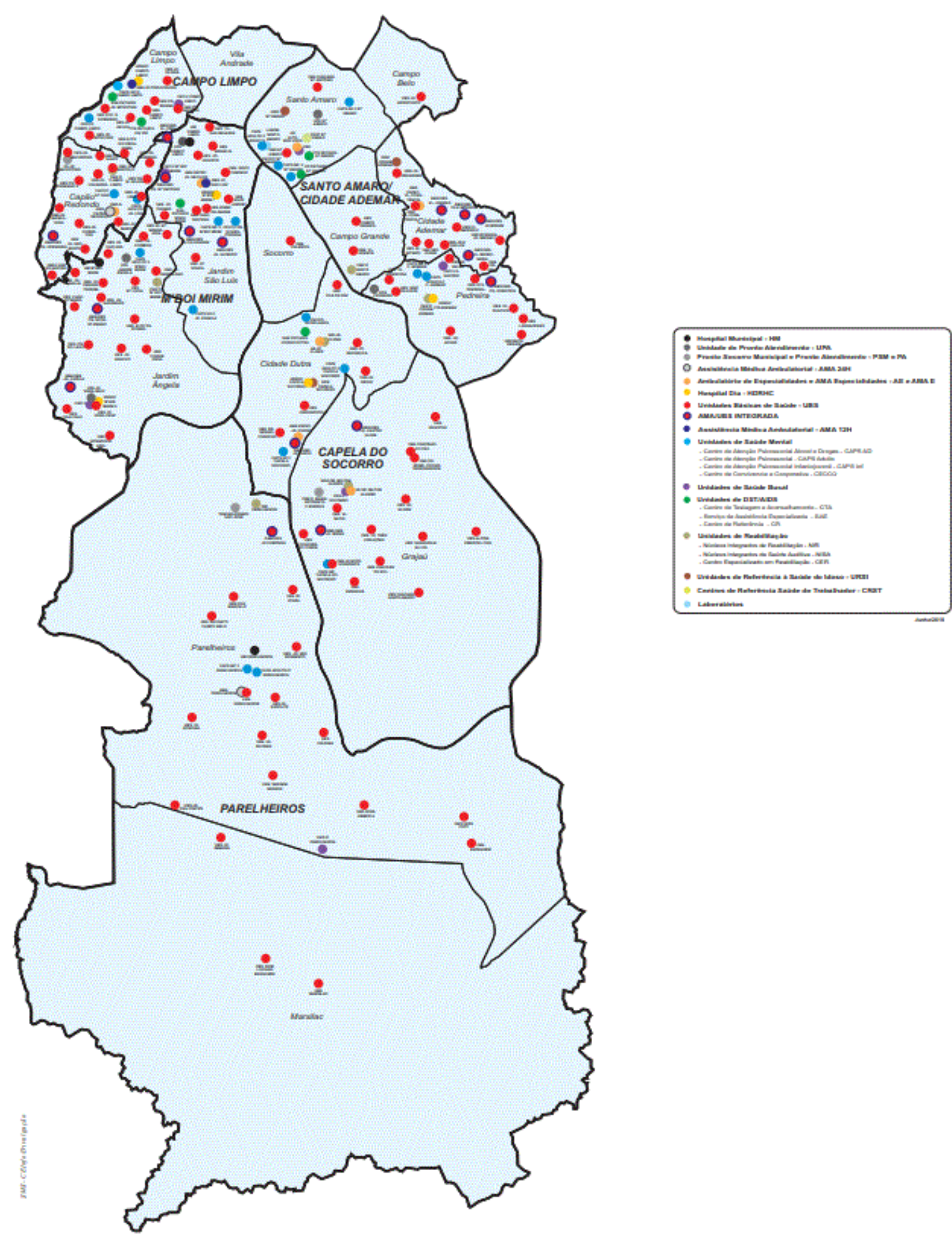

Fonte: São Paulo, Secretaria Municipal de Saúde, Coordenação de Epidemiologia e Informação (CEInfo). Estabelecimentos e Serviços de Saúde da Rede Municipal - Coordenadoria Regional de Saúde Sul [Internet]. São Paulo; 2018 [atualizado 2018 set; citado 2019 jan. 16]. Disponível em: https://www.prefeitura.sp.gov.br/cidade/secretarias/upload/saude/arquivos/ceinfo/mapoteca/crs_sul_st s.pdf 
O estudo foi realizado em unidade de saúde com ESF na Região Sul do município de São Paulo.

Os critérios de inclusão para os participantes do estudo foram: ser Agente Comunitário de Saúde (ACS), Auxiliar de Enfermagem ou Enfermeiro das equipes da ESF desta unidade.

\subsection{COLETA E ANÁLISE DE DADOS}

Foi elaborado pela pesquisadora um questionário autoaplicável (APÊNDICE A), contendo 24 questões sobre imunização. As duas primeiras questões interrogam o profissional sobre a orientação de contraindicação ou adiamento de vacinação dados, no cotidiano de trabalho, aos pais/responsáveis por crianças na área de abrangência da UBS. Os profissionais poderiam responder que não davam essas orientações ou que as faziam em situações que eles listariam. A última questão requeria que o participante relacionasse 02 colunas: a primeira com nomenclaturas de 09 vacinas disponíveis na rede pública de saúde, e a segunda com as doenças contra as quais elas protegem. As demais 21 questões eram objetivas, e o profissional poderia responder "Sim", "Não" e "Não sei" para cada uma delas, e discorriam sobre aspectos relacionados ao conhecimento dos profissionais sobre doses e reforços das vacinas, cobertura vacinal e sua relação com a morbimortalidade por doenças imunopreviníveis, noções básicas de imunologia das vacinas, oportunidade perdida em imunização, riscos inerentes à não vacinação de crianças, controle de qualidade das vacinas aplicadas no SUS, crenças e comportamentos dos pais e responsáveis

pelas crianças que interferem na adesão à vacinação, acolhimento e responsabilidade da equipe de saúde quanto à vacinação.

Em um primeiro momento, foi aplicado o questionário para avaliar 0 conhecimento inicial dos sujeitos. Foi disponibilizado tempo de 30 minutos para responder ao questionário. O tempo mínimo utilizado pelos profissionais foi de 07 minutos, e o máximo de 28 minutos.

Foram 55 os profissionais entrevistados, sendo 39 ACS, 12 Auxiliares de Enfermagem e 04 Enfermeiros.

Após a aplicação do questionário, foi realizada ação educativa através de aula expositiva, com utilização do programa Power Point, abrangendo temas relacionados à imunização, doenças imunopreveníveis, aspectos organizacionais do PNI, calendário vacinal, barreiras de acesso à imunização, fatores que interferem na 
não vacinação, oportunidades perdidas em imunização, verdadeiras e falsas contraindicações às vacinações, entre outros. A duração da ação educativa foi de 1h30min, destacando-se que os sujeitos puderam expor suas dúvidas à pesquisadora, responsável por desenvolvê-la.

Após o término da ação educativa, foi aplicado o mesmo questionário utilizado inicialmente, a fim de identificar se houve incremento do conhecimento dos participantes acerca dos temas abordados.

Os dados obtidos dos questionários foram tabulados em programa Excel e foi realizada análise de frequência simples.

\subsection{CONSIDERAÇÕES ÉTICAS}

O projeto foi submetido ao Comitê de Ética em Pesquisa da Escola de Enfermagem, como instituição proponente, e ao Comitê de Ética e Pesquisa da Secretaria Municipal de Saúde de São Paulo, como instituição coparticipante, sendo aprovado pelas duas instituições, CAAE: 16498919.3.0000.5392, segundo parecer consubstanciado (APÊNDICE B).

A aplicação do questionário foi realizada após convite aos profissionais para participar do estudo, e anuência através da apresentação do Termo de Consentimento Livre e Esclarecido - TCLE - (APÊNDICE C).

Devido ao fato de o treinamento ter sido aplicado em ambiente de trabalho dos participantes, houve a precaução, por parte da pesquisadora, de orientá-los, em vários momentos, que os mesmos não seriam avaliados profissionalmente e nem sofreriam sanções a depender dos resultados obtidos, e os questionários não foram nomeados. 


\section{RESULTADOS}

\subsection{CARACTERIZAÇÃO DOS PARTICIPANTES}

Participaram da aplicação do questionário pré-intervenção, inicialmente, 55 profissionais, sendo 39 agentes comunitários de saúde, 12 auxiliares de enfermagem e 4 enfermeiras, todos componentes das equipes da ESF. Porém, 3 profissionais não responderam ao questionário pós-intervenção. Sendo assim, o número total de profissionais foi diferente para as análises destes dois momentos. Desta forma, optamos por expor os resultados comparando as respostas às questões, de acordo com o número relativo.

Gráfico 1. Distribuição dos sujeitos do estudo segundo faixa etária. São Paulo, 2019.

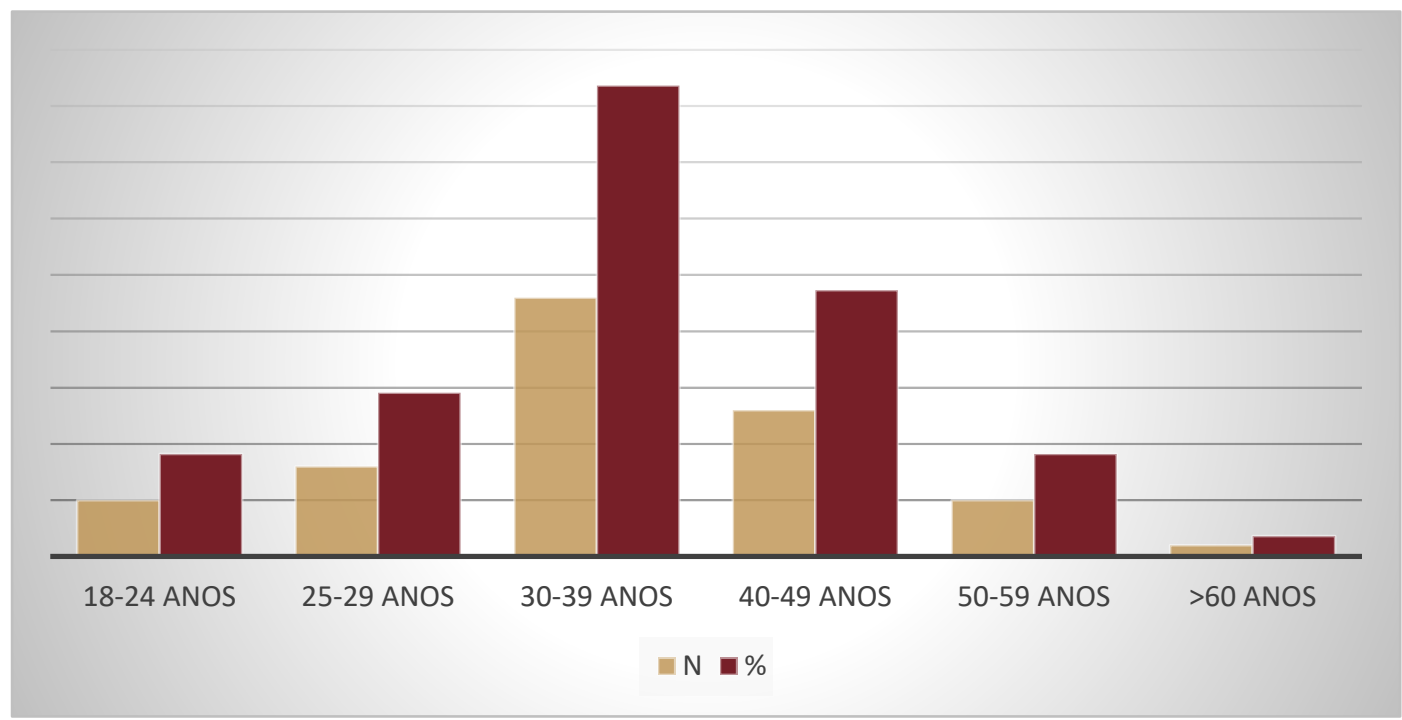

Os participantes do estudo têm idade na faixa etária de 18 a maior de 60 anos, sendo que $41,8 \%$ estão na faixa etária entre 30 a 39 anos de idade. 
Gráfico 2. Distribuição dos sujeitos do estudo segundo grau de escolaridade e formação na área da saúde. São Paulo, 2019.

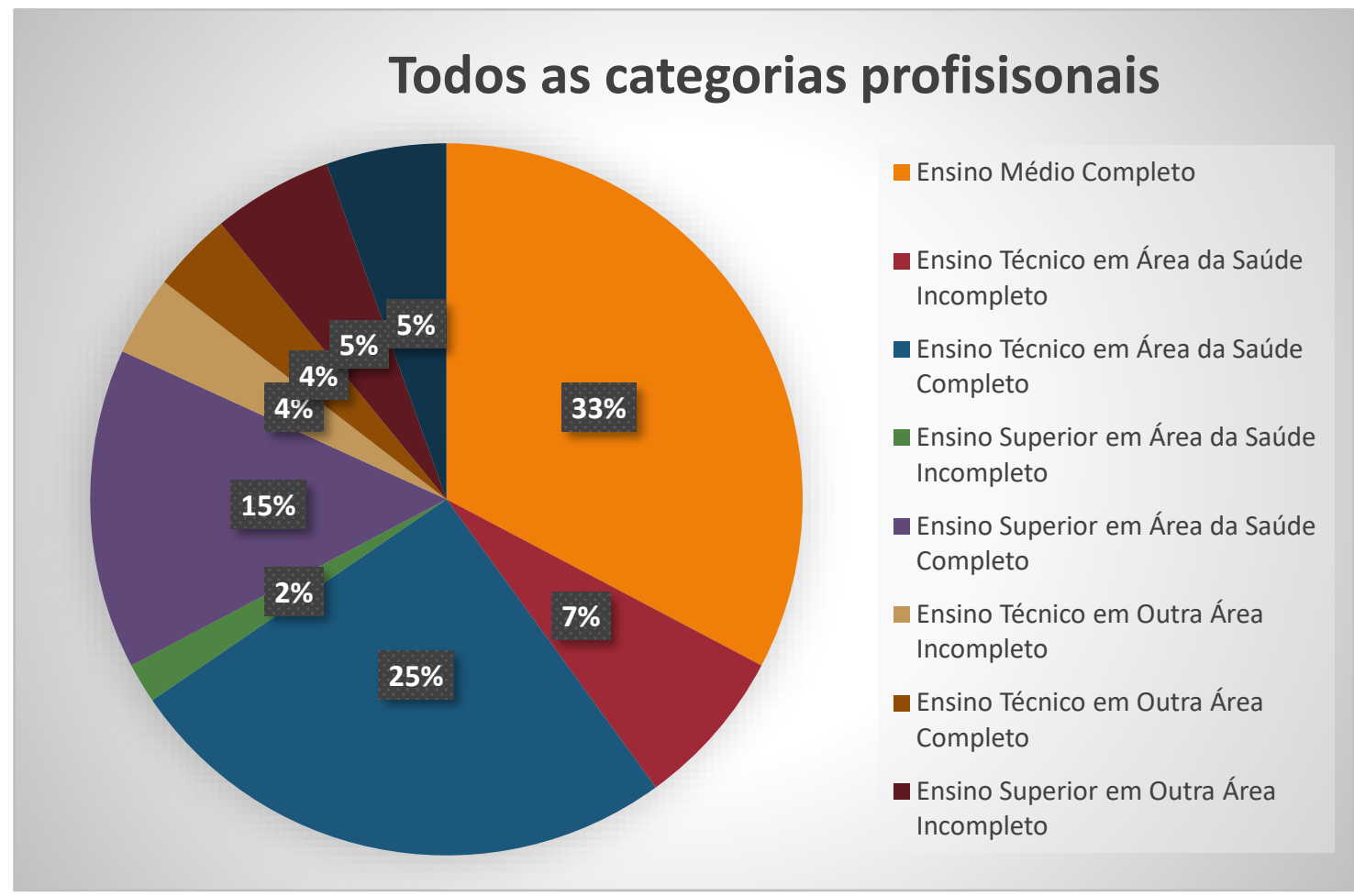

Gráfico 3. Distribuição da categoria ACS segundo grau de escolaridade formação na área da saúde. São Paulo, 2019.

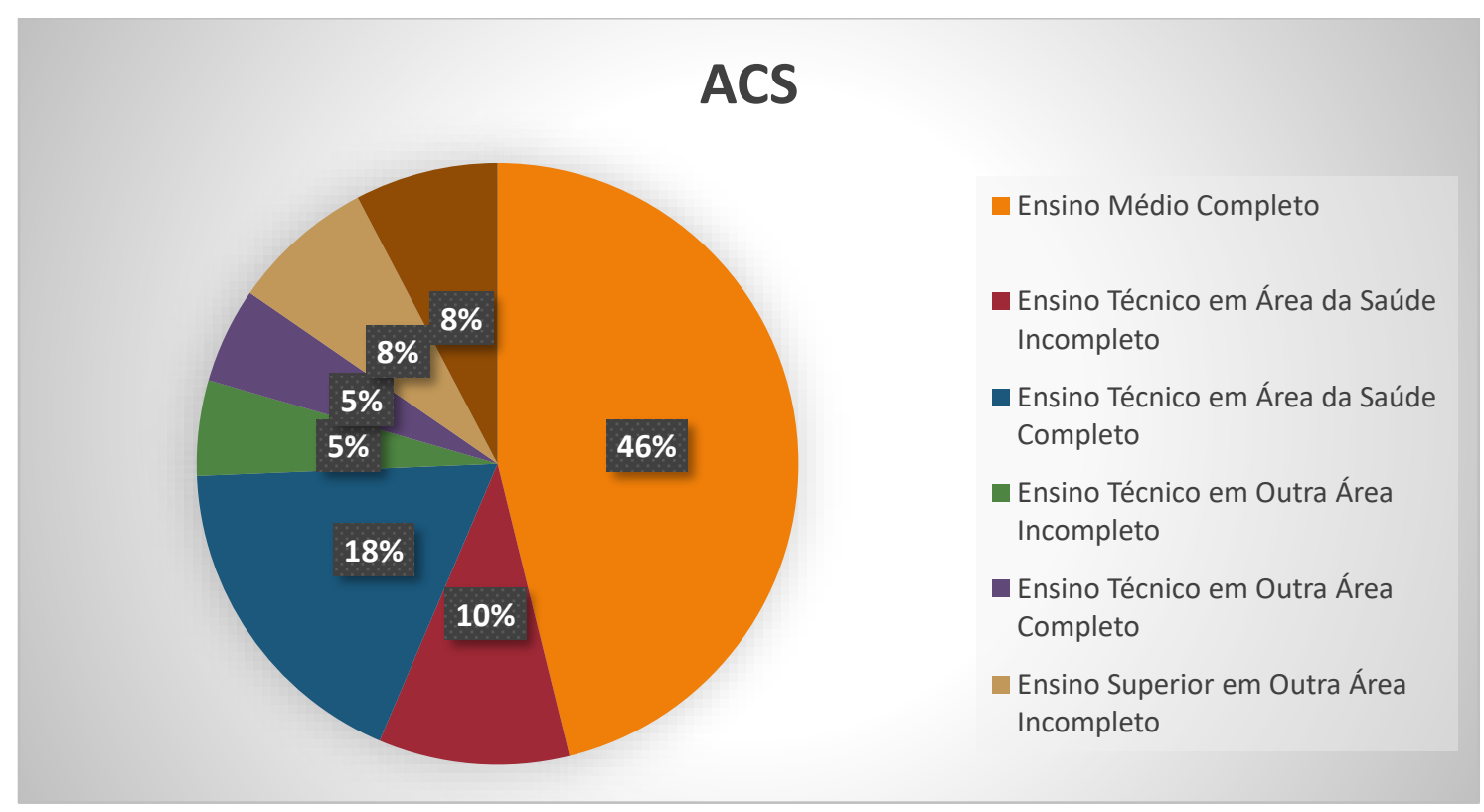


Gráfico 4. Distribuição da categoria Auxiliar de Enfermagem segundo grau de escolaridade formação na área da saúde. São Paulo, 2019.

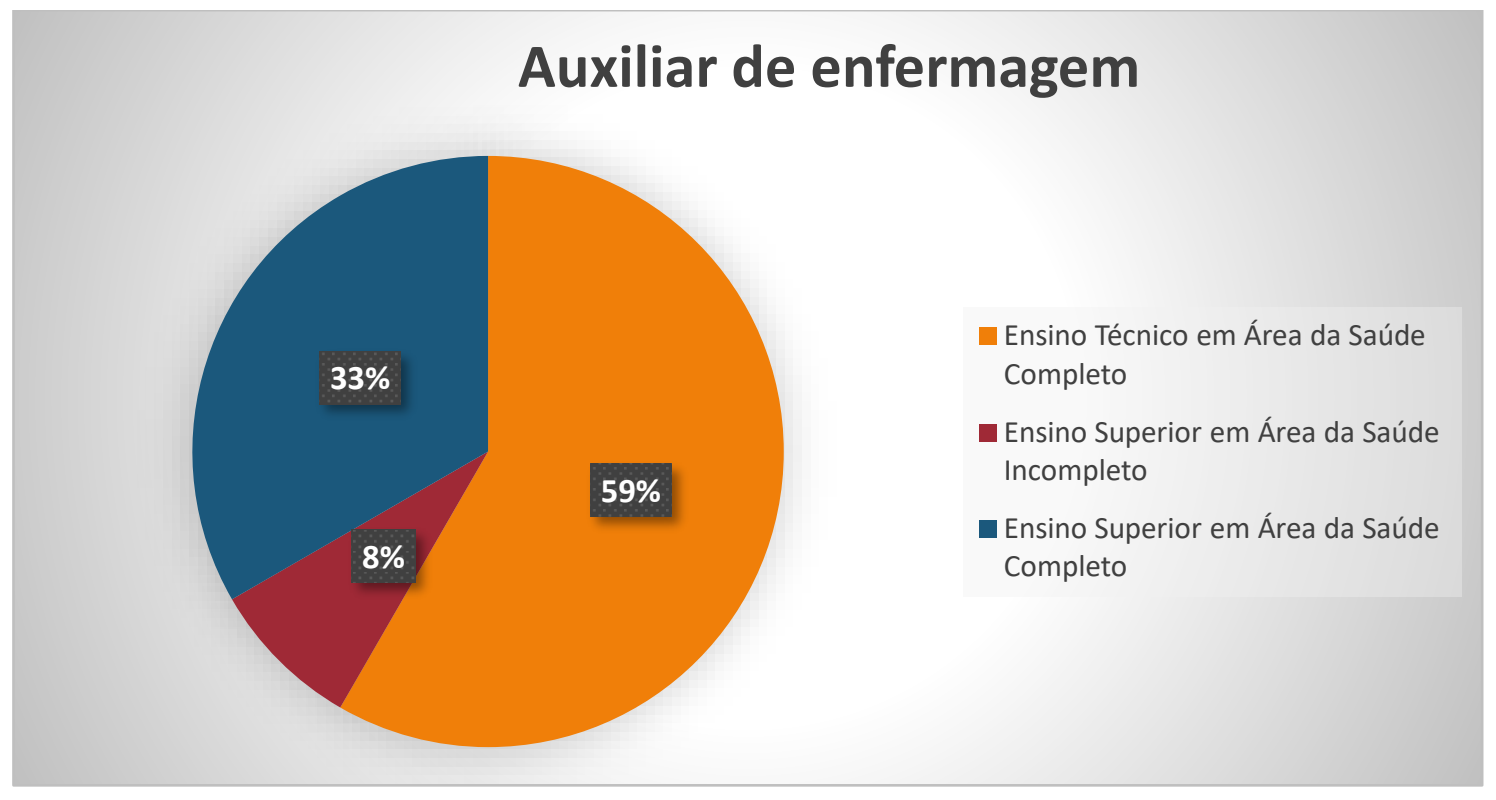

Observa-se que $46,0 \%$ dos ACS tem a formação mínima exigida para a função - ensino médio completo, porém, a maioria destes profissionais apresenta, também, outras formações, sendo estas ensino técnico completo ou incompleto e ensino superior incompleto. A maior parte dos auxiliares de enfermagem também possui a formação exigida para a função - ensino técnico na área de enfermagem, destacando-se que $41,0 \%$ já possui graduação na área da saúde completa ou em curso. Evidentemente que todas as enfermeiras possuem ensino superior completo, conforme exigido pela função, e a participação em cursos de pós-graduação senso lato e estrito não foi questionada. 
Gráfico 5. Distribuição dos sujeitos do estudo segundo tempo de trabalho na função exercida. São Paulo, 2019.

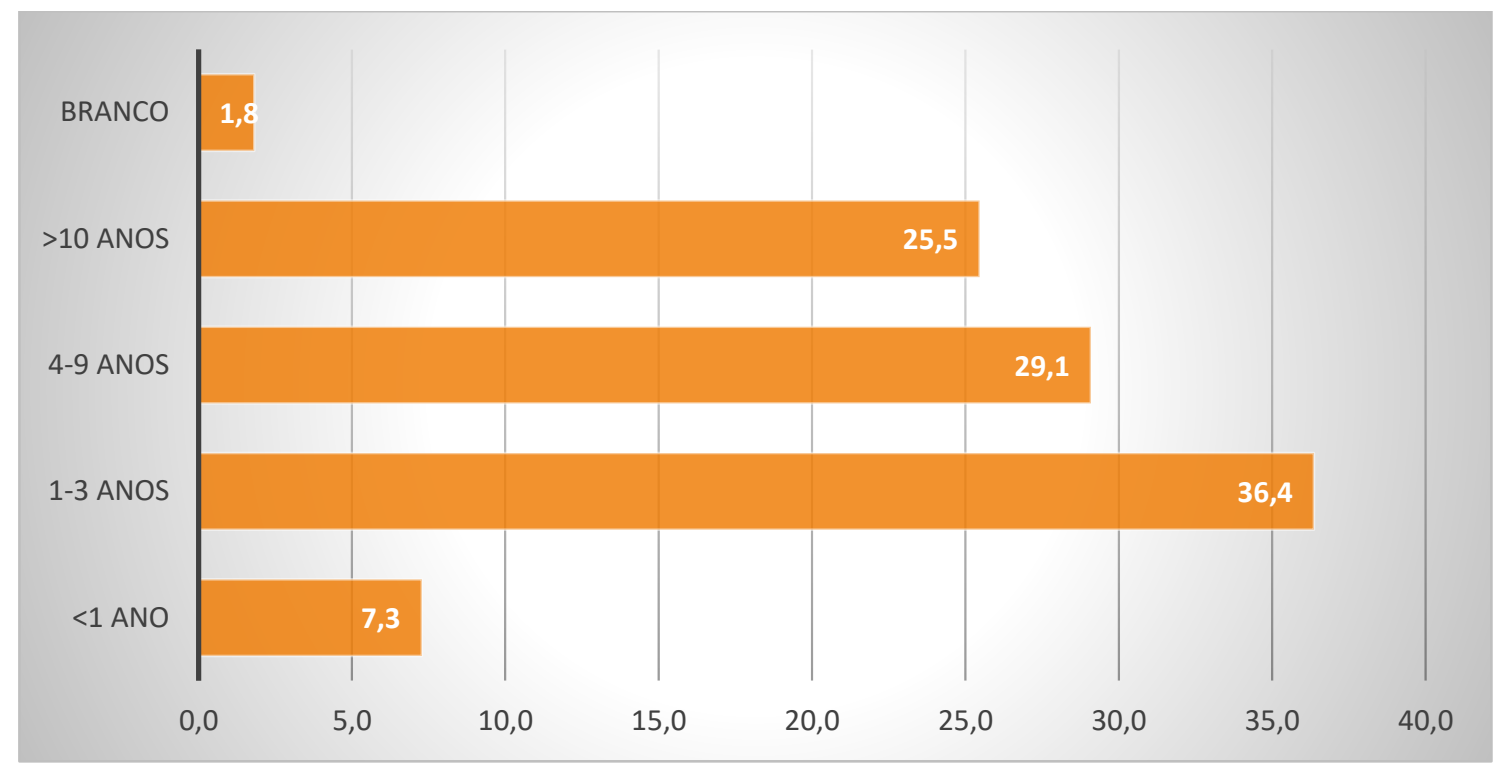

Apenas 4 profissionais referiram trabalhar na função exercida há menos de 1 ano, o que corresponde à $7,3 \%$, e a maior parte $(36,4 \%)$ entre 1-3 anos. Mas, também, verificou-se expressão em relação ao número de profissionais que atuavam na função entre $4-9$ anos $(29,1 \%)$ e em período maior que 10 anos $(25,5 \%)$.

Gráfico 6. Distribuição dos sujeitos do estudo segundo participação em ação educativa prévia sobre imunização. São Paulo, 2019.

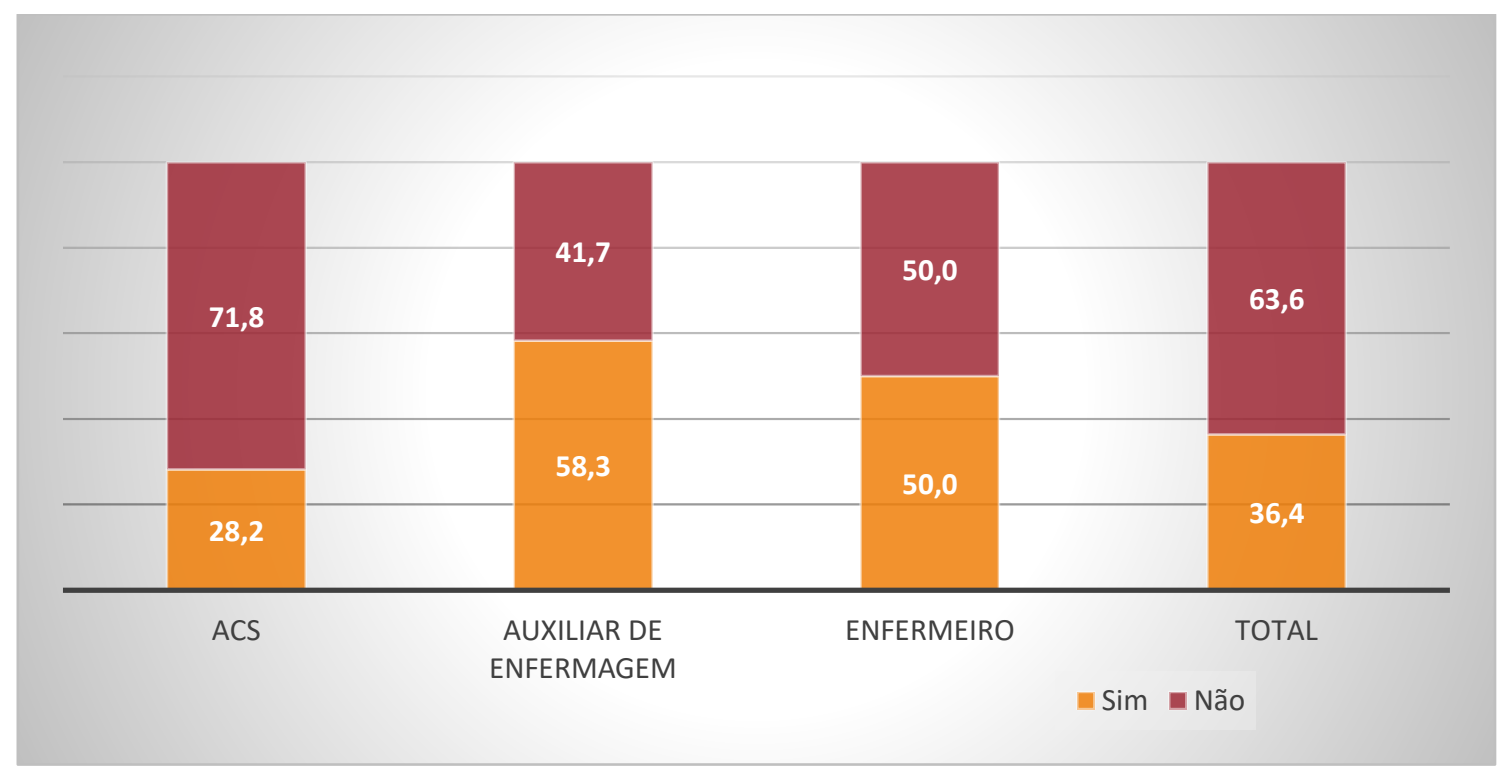


Observa-se que a categoria profissional de auxiliares de enfermagem é a que possui maior proporção de profissionais que já haviam passado por alguma atividade educativa sobre imunização, e que apenas $28,2 \%$ dos ACS haviam sido submetidos a esse tipo de intervenção. Cerca de um terço da população total não tinha participado de capacitação sobre o tema previamente ao presente estudo. 


\subsection{CONHECIMENTO DOS SUJEITOS E AVALIAÇÃO DA APRENDIZAGEM}

Optou-se por apresentar os dados de cada questão aplicada, comparando as respostas pré e pós-intervenção para todos os profissionais (geral) e para cada categoria profissional, a fim de avaliar a aprendizagem obtida através da atividade educativa realizada. Seguem os resultados, levando-se em consideração as respostas assertivas, respostas "Não sei” e questões deixadas em branco.

Tabela 1. Situações em que o profissional orienta os responsáveis a deixar de vacinar a criança, questão 1. São Paulo, 2019.

\begin{tabular}{|c|c|c|c|c|c|c|c|}
\hline \multicolumn{4}{|c|}{ Pré-intervenção } & \multicolumn{4}{|c|}{ Pós-Intervenção } \\
\hline $\begin{array}{c}\text { Orientação a deixar de } \\
\text { vacinar }\end{array}$ & $\begin{array}{l}\text { ACS } \\
(\%)\end{array}$ & $\begin{array}{l}\text { Auxiliar } \\
(\%)\end{array}$ & $\begin{array}{l}\text { Enfermeiro } \\
(\%)\end{array}$ & $\begin{array}{l}\text { Orientação a deixar } \\
\text { de vacinar }\end{array}$ & $\begin{array}{l}\text { ACS } \\
(\%)\end{array}$ & $\begin{array}{l}\text { Auxiliar } \\
\text { (\%) }\end{array}$ & $\begin{array}{l}\text { Enfermeiro } \\
(\%)\end{array}$ \\
\hline Febre & 43,6 & 75,0 & 25,0 & Febre & 21,6 & 50,0 & 0,0 \\
\hline $\begin{array}{l}\text { Alergia à componente da } \\
\text { vacina }\end{array}$ & 2,6 & 8,3 & 75,0 & $\begin{array}{c}\text { Alergia à } \\
\text { componente da } \\
\text { vacina }\end{array}$ & 2,7 & 8,3 & 66,7 \\
\hline $\begin{array}{c}\text { Questões de saúde que } \\
\text { impossibilitem a criança } \\
\text { de ser vacinada }\end{array}$ & 0,0 & 0,0 & 25,0 & $\begin{array}{l}\text { Reação anafilática } \\
\text { em dose anterior }\end{array}$ & 5,4 & 16,7 & 0,0 \\
\hline Contraindicação médica & 5,1 & 0,0 & 0,0 & $\begin{array}{c}\text { Reação anafilática à } \\
\text { ovo }\end{array}$ & 2,7 & 8,3 & 0,0 \\
\hline Doença na criança & 2,6 & 0,0 & 0,0 & $\begin{array}{c}\text { Reação grave a dose } \\
\text { anterior }\end{array}$ & 2,7 & 0,0 & 33,3 \\
\hline $\begin{array}{l}\text { Faixa etária não indicada } \\
\text { para determinada vacina }\end{array}$ & 2,6 & 0,0 & 0,0 & Convulsão & 2,7 & 0,0 & 0,0 \\
\hline $\begin{array}{l}\text { Intervalo entre uma } \\
\text { vacina e outra }\end{array}$ & 2,6 & 0,0 & 0,0 & $\begin{array}{c}\text { Choro intenso na } \\
\text { criança após dose } \\
\text { anterior }\end{array}$ & 2,7 & 0,0 & 0,0 \\
\hline Pós-operatório & 2,6 & 0,0 & 0,0 & $\begin{array}{c}\text { Uso de } \\
\text { imunossupressor }\end{array}$ & 0,0 & 8,3 & 33,3 \\
\hline Outra situação & 2,6 & 0,0 & 0,0 & $\begin{array}{l}\text { Tratamento de } \\
\text { Câncer }\end{array}$ & 0,0 & 8,3 & 33,3 \\
\hline $\begin{array}{c}\text { Orienta responsável a } \\
\text { procurar a UBS em caso } \\
\text { de febre ou outras } \\
\text { situações }\end{array}$ & 2,6 & 0,0 & 0,0 & Transplante & 0,0 & 8,3 & 33,3 \\
\hline
\end{tabular}


Tabela 2. Situações em que o profissional orienta os responsáveis a adiar a vacinação da criança, questão 2. São Paulo, 2019.

\begin{tabular}{|c|c|c|c|}
\hline \multicolumn{4}{|c|}{ Pré-intervenção } \\
\hline $\begin{array}{c}\text { Orientação a } \\
\text { adiar a vacinação }\end{array}$ & $\begin{array}{l}\text { ACS } \\
(\%)\end{array}$ & $\begin{array}{c}\text { Auxiliar } \\
\text { (\%) }\end{array}$ & $\begin{array}{c}\text { Enfermeiro } \\
(\%)\end{array}$ \\
\hline Febre & 84,6 & 66,7 & 100,0 \\
\hline $\begin{array}{c}\text { Alergia à } \\
\text { componente da } \\
\text { vacina }\end{array}$ & 2,6 & 0,0 & 25,0 \\
\hline Doença na criança & 5,1 & 8,3 & 0,0 \\
\hline Pós-operatório & 2,6 & 0,0 & 0,0 \\
\hline Uso de corticoide & 0,0 & 8,3 & 0,0 \\
\hline $\begin{array}{l}\text { Evento adverso } \\
\text { em dose anterior }\end{array}$ & 2,6 & 8,3 & 0,0 \\
\hline $\begin{array}{l}\text { Criança com } \\
\text { alguma infecção }\end{array}$ & 2,6 & 0,0 & 0,0 \\
\hline Uso de antibiótico & 5,1 & 0,0 & 25,0 \\
\hline $\begin{array}{l}\text { Uso de alguma } \\
\text { medicação que } \\
\text { contraindique } \\
\text { vacinação }\end{array}$ & 2,6 & 0,0 & 0,0 \\
\hline $\begin{array}{c}\text { Uso de } \\
\text { antialérgico }\end{array}$ & 2,6 & 8,3 & 0,0 \\
\hline $\begin{array}{l}\text { Intervalo entre } \\
\text { uma vacina e outra }\end{array}$ & 2,6 & 8,3 & 0,0 \\
\hline $\begin{array}{c}\text { Criança vacinada } \\
\text { há menos de } 30 \\
\text { dias }\end{array}$ & 2,6 & 0,0 & 0,0 \\
\hline
\end{tabular}

\begin{tabular}{|c|c|c|c|}
\hline \multicolumn{4}{|c|}{ Pós-Intervenção } \\
\hline $\begin{array}{c}\text { Orientação a } \\
\text { adiar a } \\
\text { vacinação }\end{array}$ & $\begin{array}{l}\text { ACS } \\
(\%)\end{array}$ & $\begin{array}{l}\text { Auxiliar } \\
(\%)\end{array}$ & $\begin{array}{c}\text { Enfermeiro } \\
(\%)\end{array}$ \\
\hline Febre & 59,5 & 83,3 & 66,7 \\
\hline $\begin{array}{l}\text { Alergia à } \\
\text { componente da } \\
\text { vacina }\end{array}$ & 0,0 & 8,3 & 33,3 \\
\hline $\begin{array}{l}\text { Doença na } \\
\text { criança }\end{array}$ & 2,7 & 16,7 & 0,0 \\
\hline Pós-operatório & 2,7 & 0,0 & 0,0 \\
\hline Uso de corticoide & 2,7 & 8,3 & 0,0 \\
\hline $\begin{array}{l}\text { Reação grave à } \\
\text { dose anterior }\end{array}$ & 2,7 & 0,0 & 0,0 \\
\hline Convulsão & 2,7 & 0,0 & 33,3 \\
\hline $\begin{array}{l}\text { Choro intenso na } \\
\text { criança após } \\
\text { dose anterior }\end{array}$ & 2,7 & 0,0 & 0,0 \\
\hline Diarreia & 2,7 & 0,0 & 0,0 \\
\hline $\begin{array}{l}\text { Febre acima de } \\
\qquad 39^{\circ}\end{array}$ & 2,7 & 0,0 & 0,0 \\
\hline $\begin{array}{c}\text { Reação } \\
\text { anafilática a ovo }\end{array}$ & 0,0 & 8,3 & 0,0 \\
\hline $\begin{array}{l}\text { Vômito, nos } \\
\text { casos de vacinas } \\
\text { orais }\end{array}$ & 0,0 & 8,3 & 0,0 \\
\hline Neoplasia & 0,0 & 0,0 & 33,3 \\
\hline Transplante & 0,0 & 0,0 & 33,3 \\
\hline Amamentação & 0,0 & 0,0 & 33,3 \\
\hline Doença grave & 0,0 & 8,3 & 0,0 \\
\hline $\begin{array}{c}\text { Doenças } \\
\text { neurológicas não } \\
\text { tratadas }\end{array}$ & 0,0 & 8,3 & 0,0 \\
\hline
\end{tabular}


Gráfico 7. Índice de acertos dos participantes sobre a importância do conhecimento dos pais ou responsáveis pela criança acerca das doenças imunopreveníveis, questão 3. São Paulo, 2019.

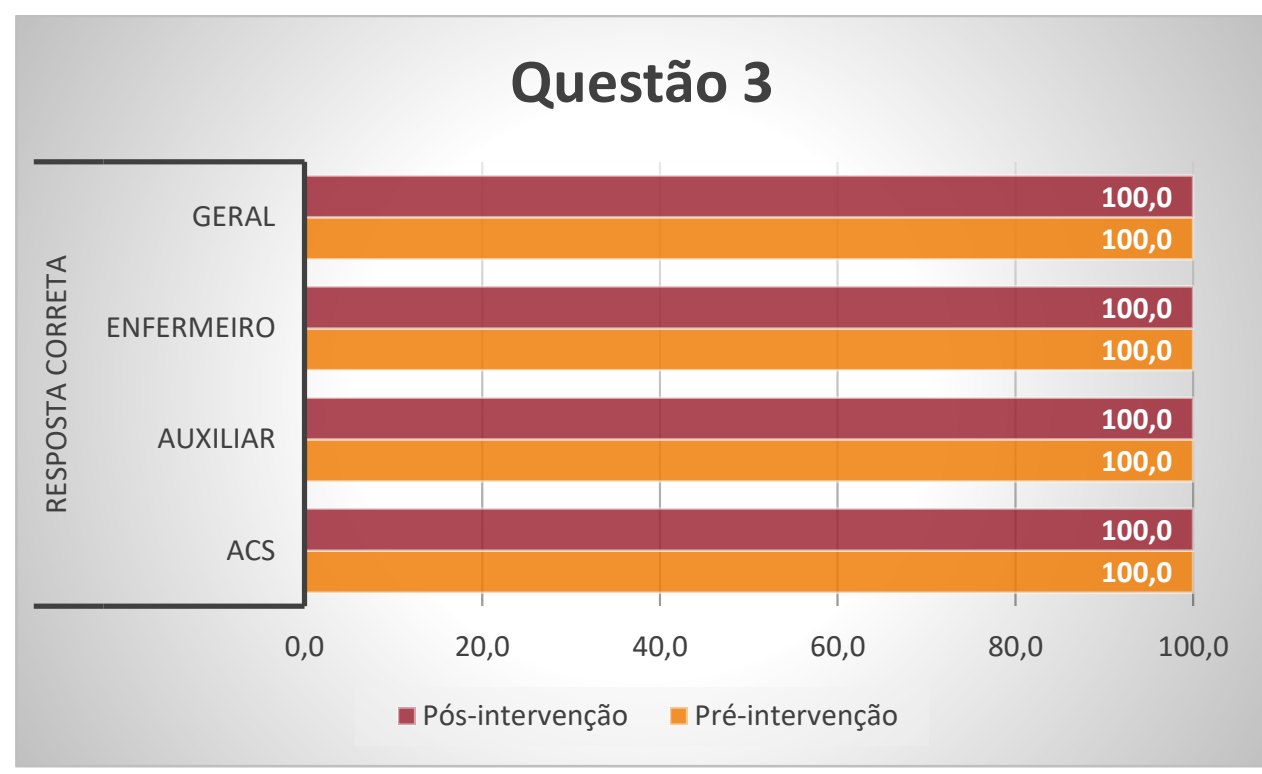

Observa-se que todos os participantes da pesquisa responderam assertivamente a esta questão, apontando ciência e sensibilização destes quanto à importância do conhecimento dos pais ou responsáveis pela criança acerca das doenças imunopreveníveis.

Gráfico 8. Índice de acertos dos participantes sobre desenvolvimento da imunidade efetiva após a primeira dose de uma vacina, questão 4. São Paulo, 2019.

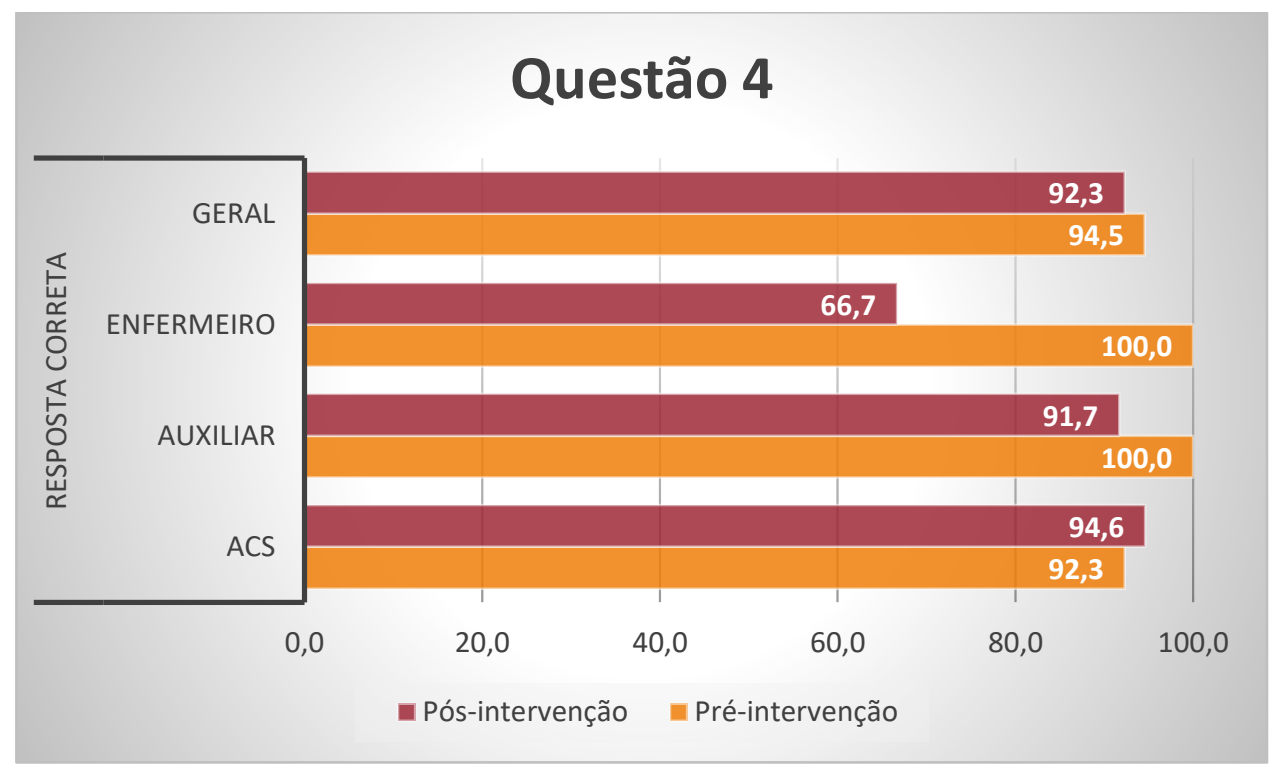


Observa-se que 94,5\% dos participantes negaram que uma criança está completamente protegida contra alguma doença após a primeira dose de uma vacina no questionário pré-intervenção, porém houve diminuição da frequência desta resposta assertiva de maneira geral nas categorias enfermeiro e auxiliar de enfermagem, e aumento desta frequência na categoria ACS, no questionário pósintervenção.

Gráfico 9. Índice de acertos dos participantes sobre erradicação de uma doença imunoprevenível em uma determinada localização em regiões com alta cobertura vacinal, questão 5. São Paulo, 2019.

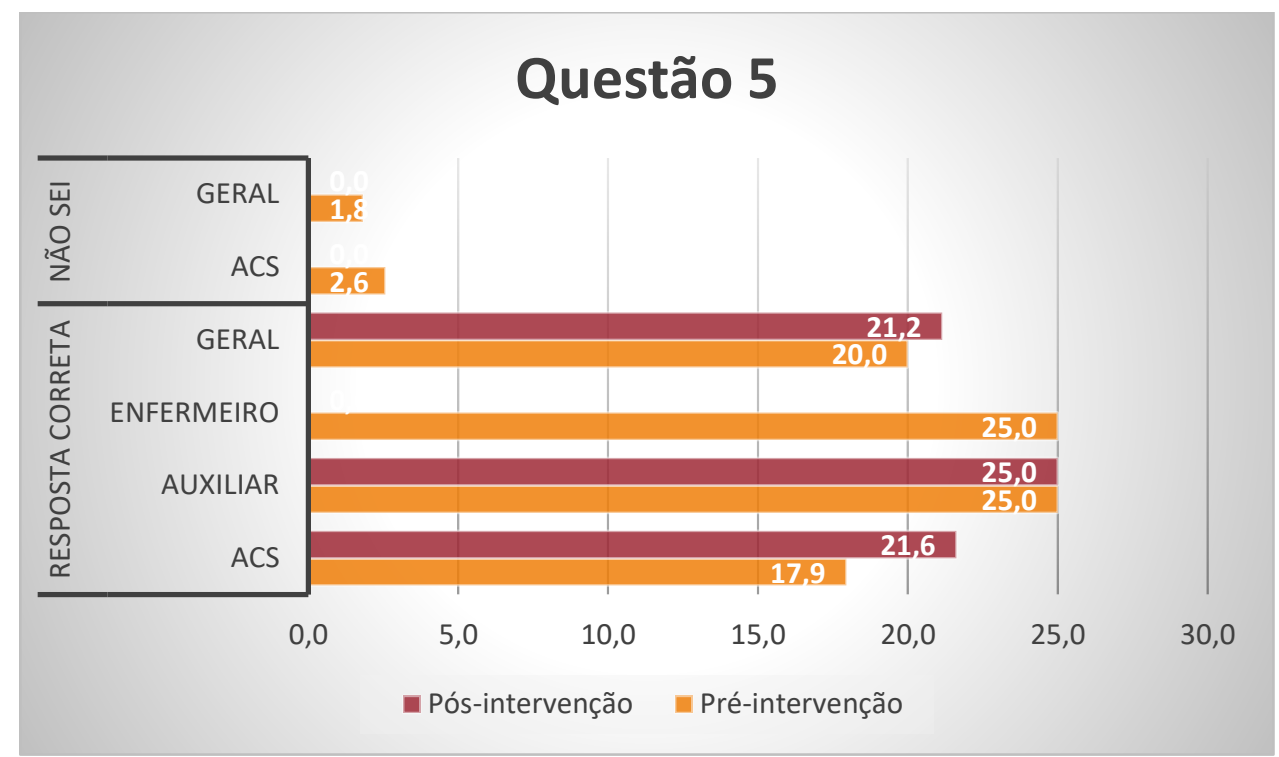

Observa-se que 20,0\% dos participantes do estudo afirmaram que uma doença imunoprevenível é eliminada em uma determinada localização em regiões com alta cobertura vacinal no questionário pré-intervenção. Após a intervenção, apenas $21,2 \%$ dos participantes da pesquisa responderam a esta questão de forma assertiva. Na categoria auxiliar de enfermagem, não houve alteração deste conhecimento. A maior alteração percebida foi para categoria ACS, em que no questionário pré-intervenção 17,9\% responderam de forma assertiva e 21,6\% 0 fizeram após a intervenção. Também na categoria ACS, 2,6\% responderam "Não sei" para esta questão no questionário pré-intervenção, e nenhum desses profissionais assinalou esta resposta após a ação educativa. 
Gráfico 10. Índice de acertos dos participantes sobre diminuição da mortalidade infantil associada a maiores coberturas vacinais, questão 6. São Paulo, 2019.

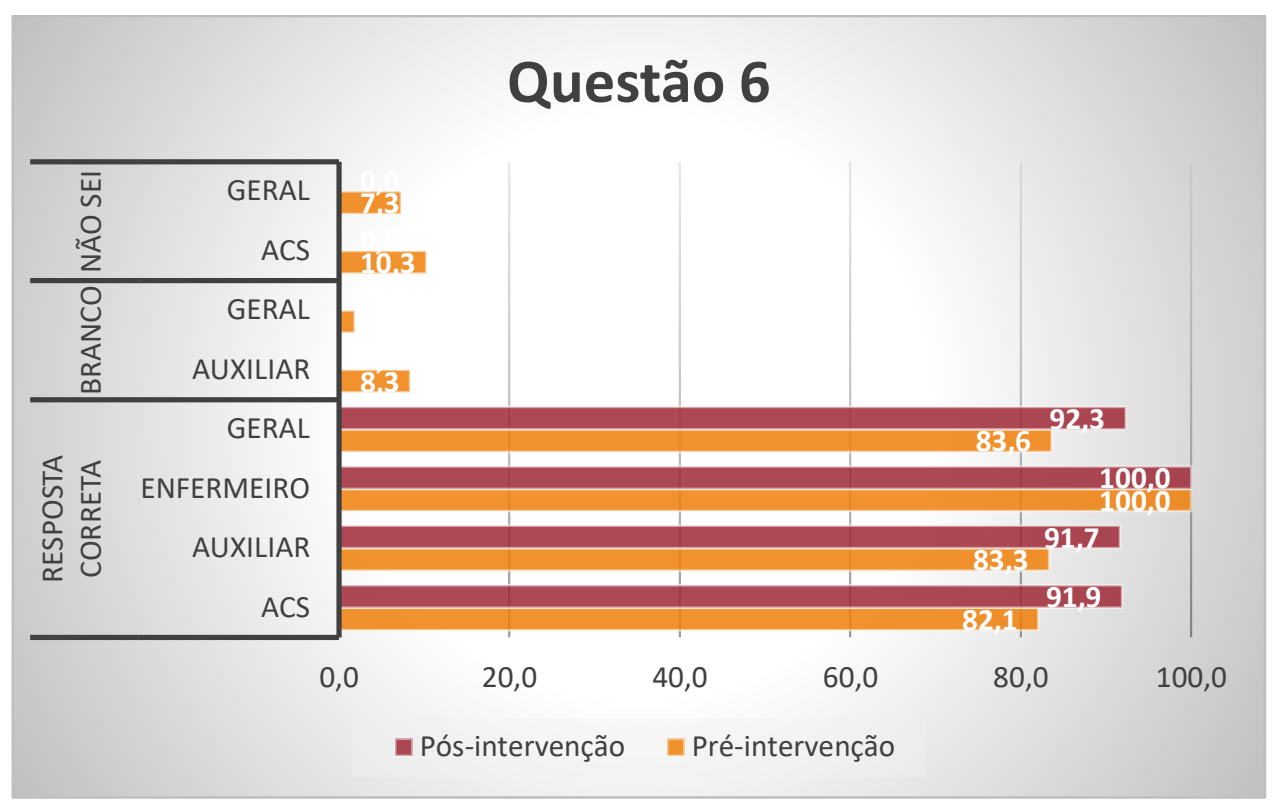

Observa-se que, por ocasião da aplicação do questionário pré-intervenção, $83,6 \%$ dos participantes responderam assertivamente que há diminuição da mortalidade infantil quando a taxa de vacinação é maior, e que houve incremento deste percentual para 92,3\% dos participantes, após a intervenção. A maior alteração percebida foi para a categoria de ACS, em que, no questionário pré-intervenção, $82,1 \%$ responderam de forma assertiva e $91,9 \%$ o fizeram após a intervenção. Também na categoria de ACS, 10,3\% responderam "Não sei" para esta questão no questionário pré-intervenção, e nenhum deles assinalou esta resposta após a ação educativa. Na categoria enfermeiro, esse conhecimento manteve-se em $100 \%$ dos profissionais. Houve percentual de $8,3 \%$ de auxiliares de enfermagem que não respondeu a esta questão no questionário pré-intervenção, e nenhum desses profissionais assinalou esta resposta após a ação educativa. 
Gráfico 11. Índice de acertos dos participantes sobre risco de vacinar crianças de pouca idade, questão 7. São Paulo, 2019.

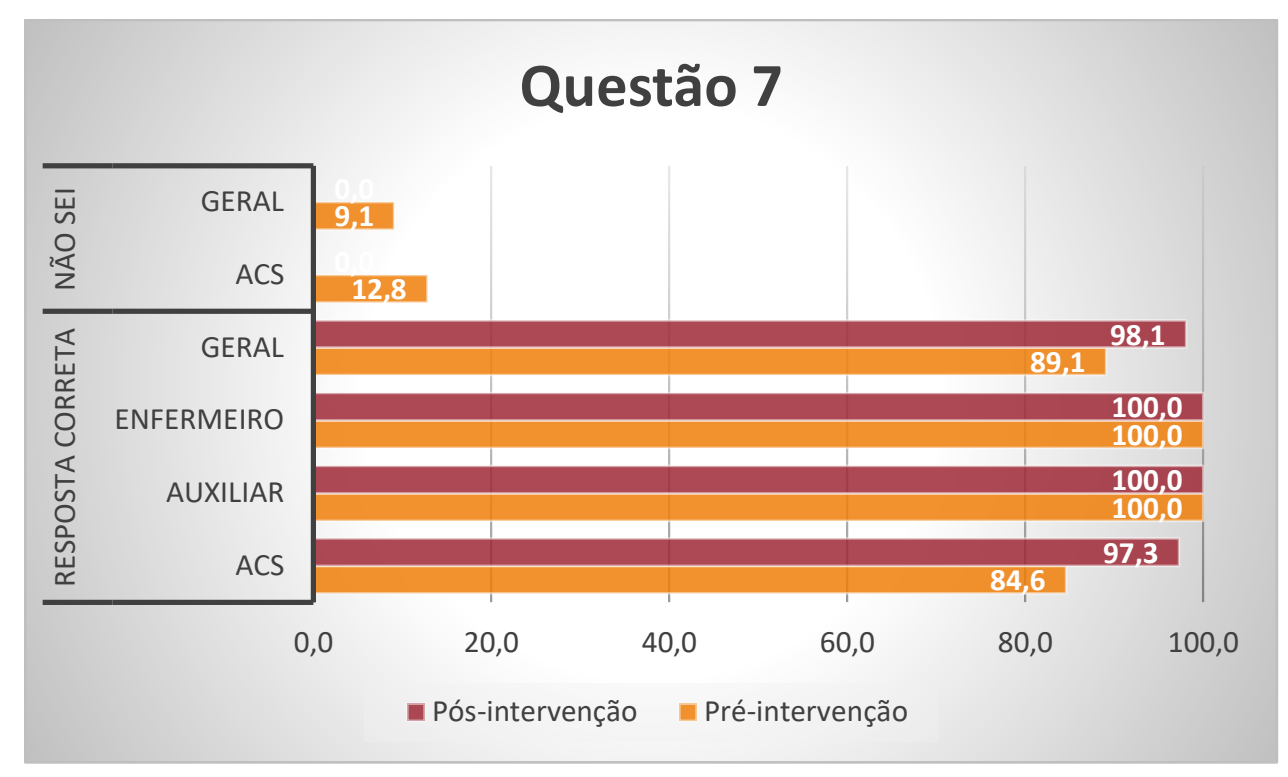

Observa-se, no questionário pré-intervenção, que $89,1 \%$ dos participantes da pesquisa negaram que há riscos em vacinar crianças de pouca idade devido à possibilidade de as mesmas não reagirem bem às vacinas, e que houve incremento deste percentual para 98,1\% dos participantes, após a intervenção. Destaca-se que nas categorias enfermeiro e auxiliar de enfermagem este conhecimento já estava presente para a totalidade desses profissionais, o que se manteve após a intervenção. Destaca-se a alteração percebida para a categoria de ACS, em que no questionário pré-intervenção $84,6 \%$ responderam de forma assertiva e 97,3\% o fizeram após a intervenção. Também em relação a esta última categoria, 12,8\% responderam "Não sei" para esta questão no questionário pré-intervenção, e nenhum assinalou esta resposta após a ação educativa. 
Gráfico 12. Índice de acertos dos participantes sobre responsabilidade da equipe de saúde quanto à busca ativa de faltosos, questão 8. São Paulo, 2019.

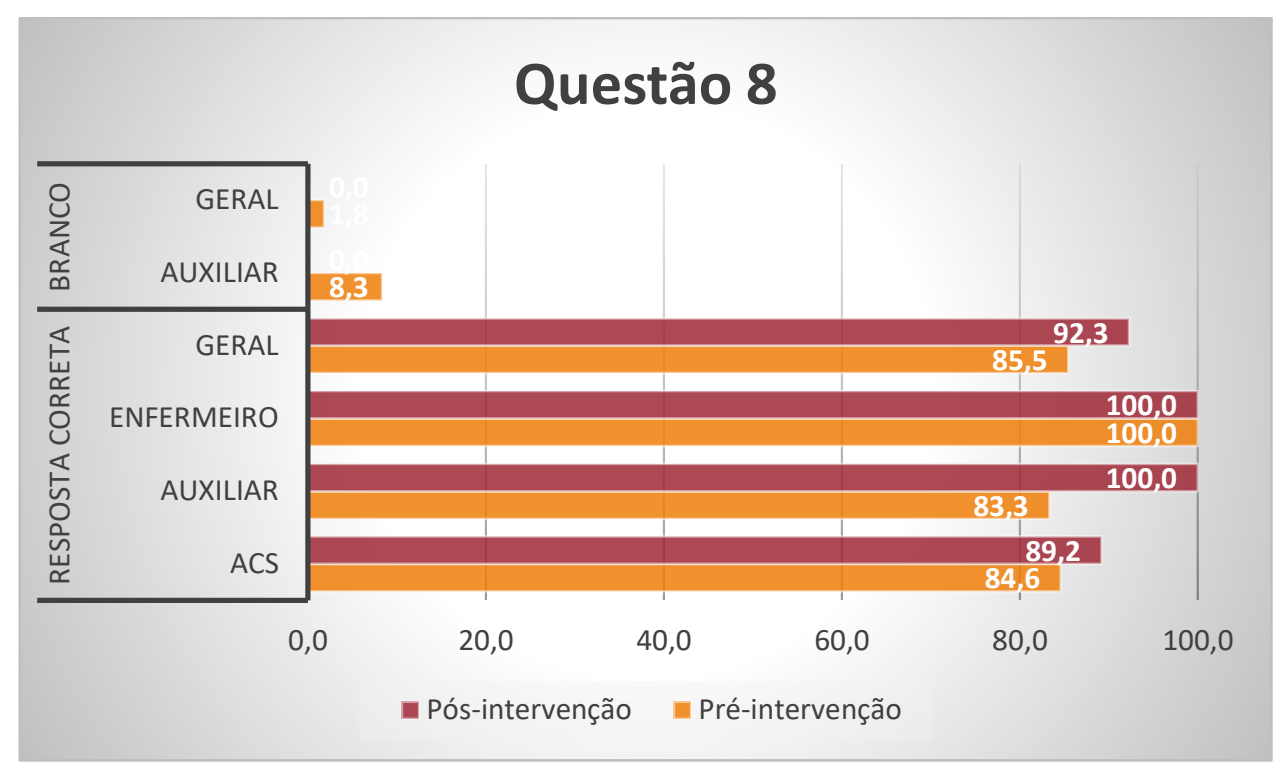

Observa-se que, no questionário pré-intervenção, 85,5\% dos participantes responderam assertivamente que é responsabilidade da equipe de saúde a busca ativa de faltosos em relação à vacinação, e que houve incremento deste percentual para 92,3\% dos participantes, após a intervenção. Na categoria enfermeiro e auxiliar de enfermagem este conhecimento já estava presente para $100 \%$ desses profissionais, mantendo-se após a intervenção. Cerca de 8,3\% dos auxiliares de enfermagem deixaram de responder a esta questão no questionário pré-intervenção, porém todos a responderam após a ação educativa. 
Gráfico 13. Índice de acertos dos participantes sobre responsabilidade da equipe de saúde quanto à orientação aos pais sobre as vacinas e as doenças imunopreveníveis, questão 9. São Paulo, 2019.

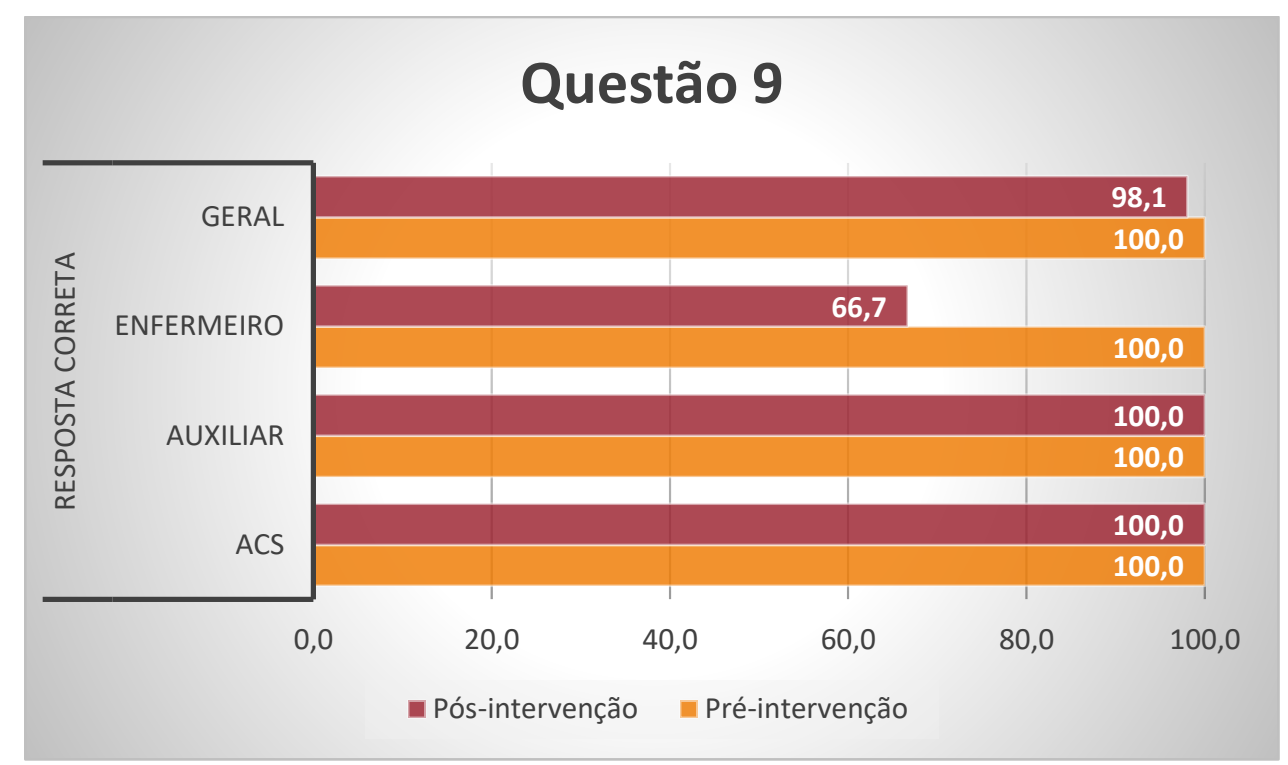

Observa-se que, na aplicação do questionário pré-intervenção, a totalidade dos participantes afirmaram que é responsabilidade da equipe de saúde a orientação aos pais sobre as vacinas e as doenças imunopreveníveis. Porém, houve diminuição da frequência desta resposta assertiva na categoria enfermeiro no questionário pósintervenção.

Gráfico 14. Índice de acertos dos participantes sobre responsabilidade exclusiva da enfermeira quanto ao acompanhamento da situação vacinal das crianças, questão 10. São Paulo, 2019.

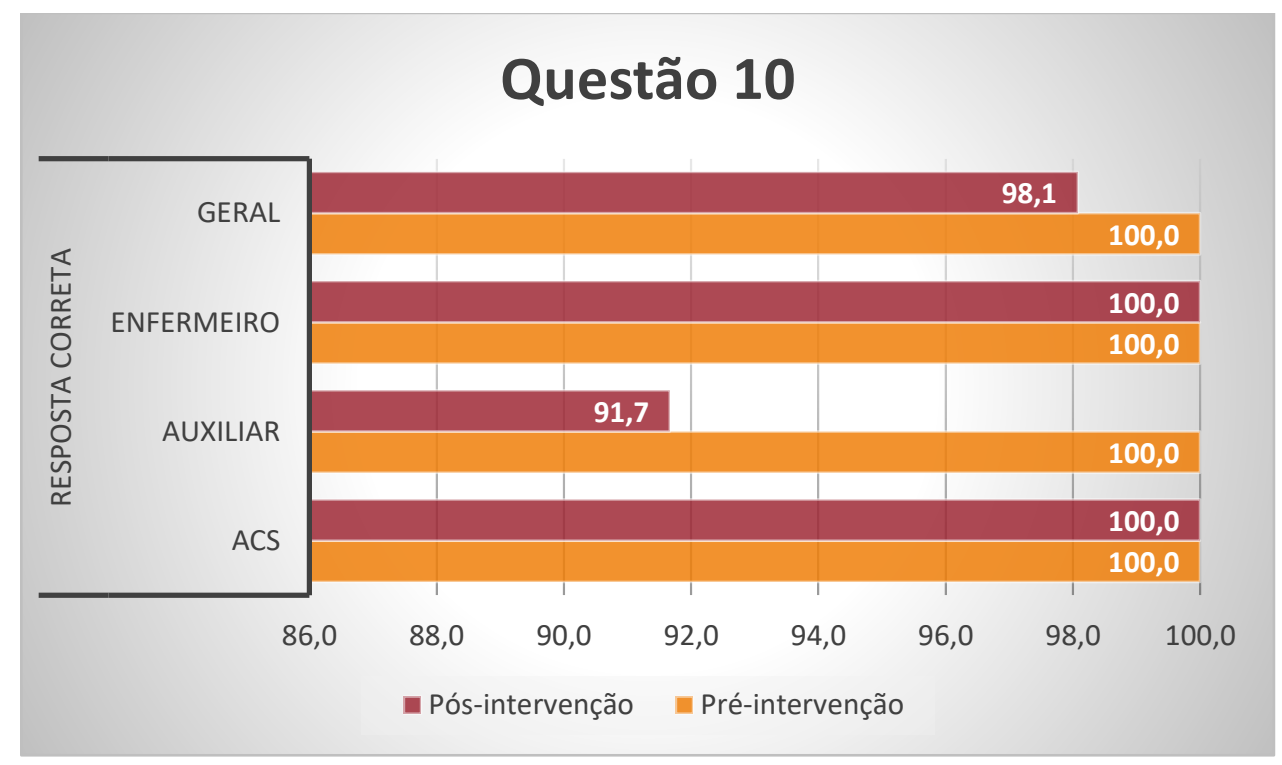


A totalidade dos participantes negaram que é responsabilidade exclusiva da enfermeira o acompanhamento da situação vacinal das crianças no questionário pré-intervenção, porém houve diminuição da frequência desta resposta assertiva na categoria auxiliar de enfermagem no instrumento pós-intervenção.

Gráfico 15. Índice de acertos dos participantes sobre crença dos pais ou responsáveis quanto a não importância da vacinação e consequente não vacinação das crianças, questão 11. São Paulo, 2019.

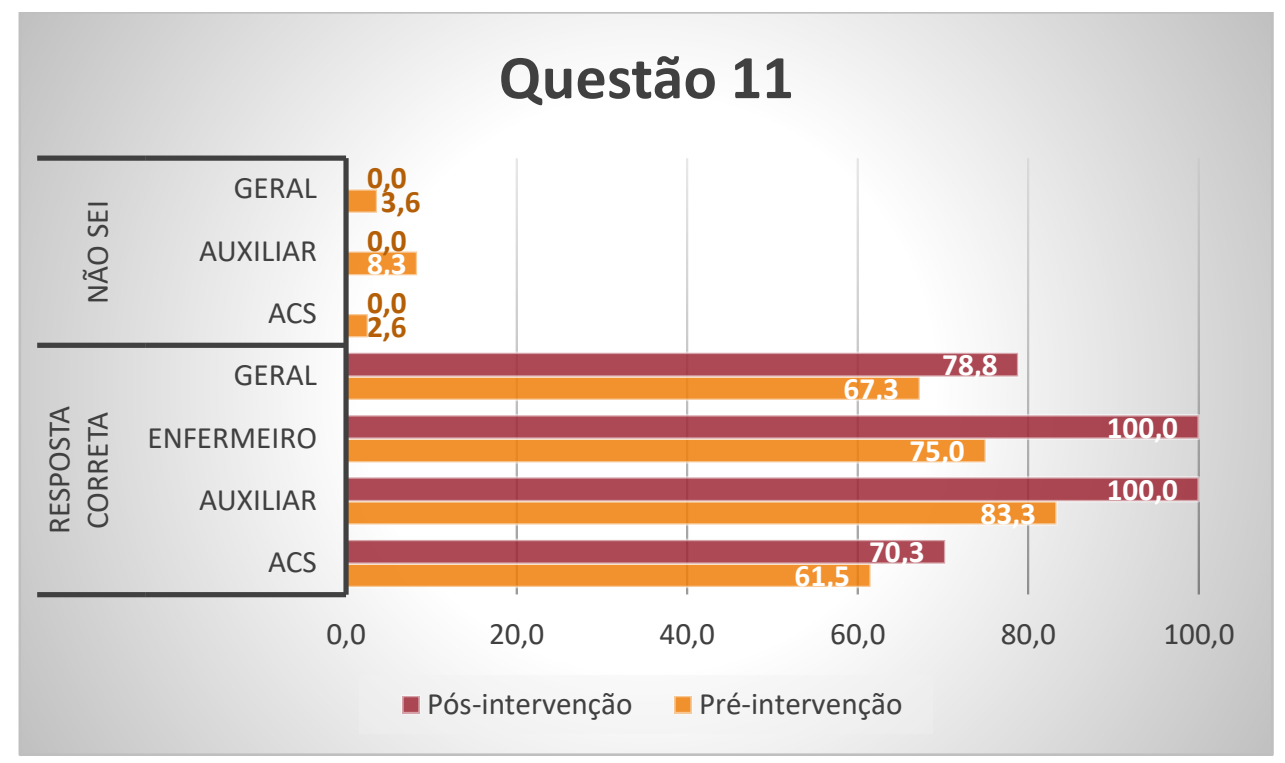

$\mathrm{Na}$ aplicação do questionário pré-intervenção, 67,3\% dos participantes afirmaram que a crença dos pais ou responsáveis quanto a não importância da vacinação pode fazer com que estes deixem de vacinar as crianças. Entretanto, houve incremento deste percentual para $78,8 \%$ dos participantes, após a intervenção. A maior alteração percebida foi para categoria enfermeiro, em que no questionário préintervenção, 75,0\% responderam de forma assertiva e 100,0\% o fizeram após a intervenção. Nas categorias auxiliar de enfermagem e de ACS, 8,3\% e 2,6\%, respectivamente, responderam "Não sei" para esta questão no questionário préintervenção, e nenhum destes profissionais assinalou esta resposta após a ação educativa. 
Gráfico 16. Índice de acertos dos participantes sobre interferência em não receber as doses de reforço para o esquema vacinal, questão 12. São Paulo, 2019.

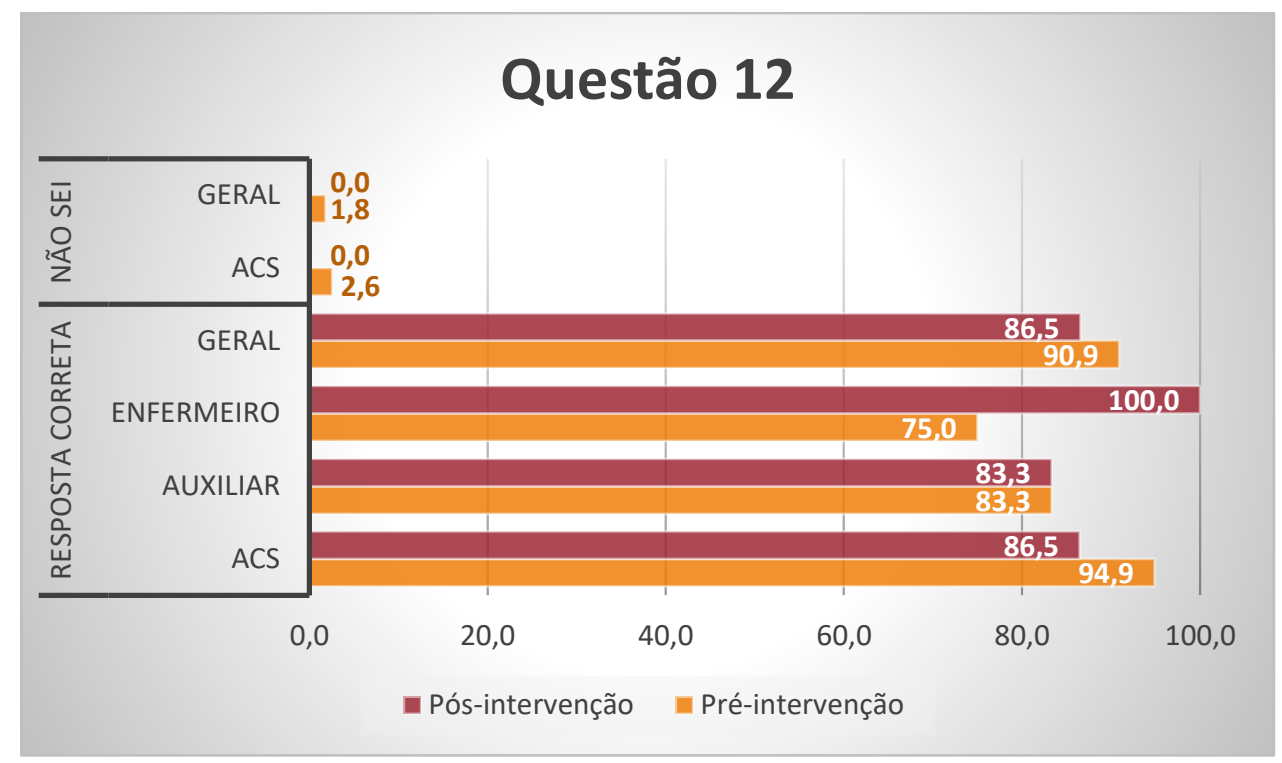

Observa-se, no questionário pré-intervenção, que 90,9\% dos participantes afirmaram que não receber as doses de reforço interfere no esquema vacinal no questionário pré-intervenção. Após a intervenção, apenas 86,5\% dos participantes da pesquisa responderam a esta questão de forma assertiva. Na categoria auxiliar de enfermagem, não houve alteração deste conhecimento (83,3\%). Na categoria ACS, houve diminuição das respostas assertivas após a intervenção. Também na categoria ACS, 2,6\% responderam "Não sei" para esta questão no questionário pré-intervenção, e nenhum destes profissionais assinalou esta resposta após a ação educativa. 
Gráfico 17. Índice de acertos dos participantes sobre oportunidades perdidas de vacinação, questão 13. São Paulo, 2019.

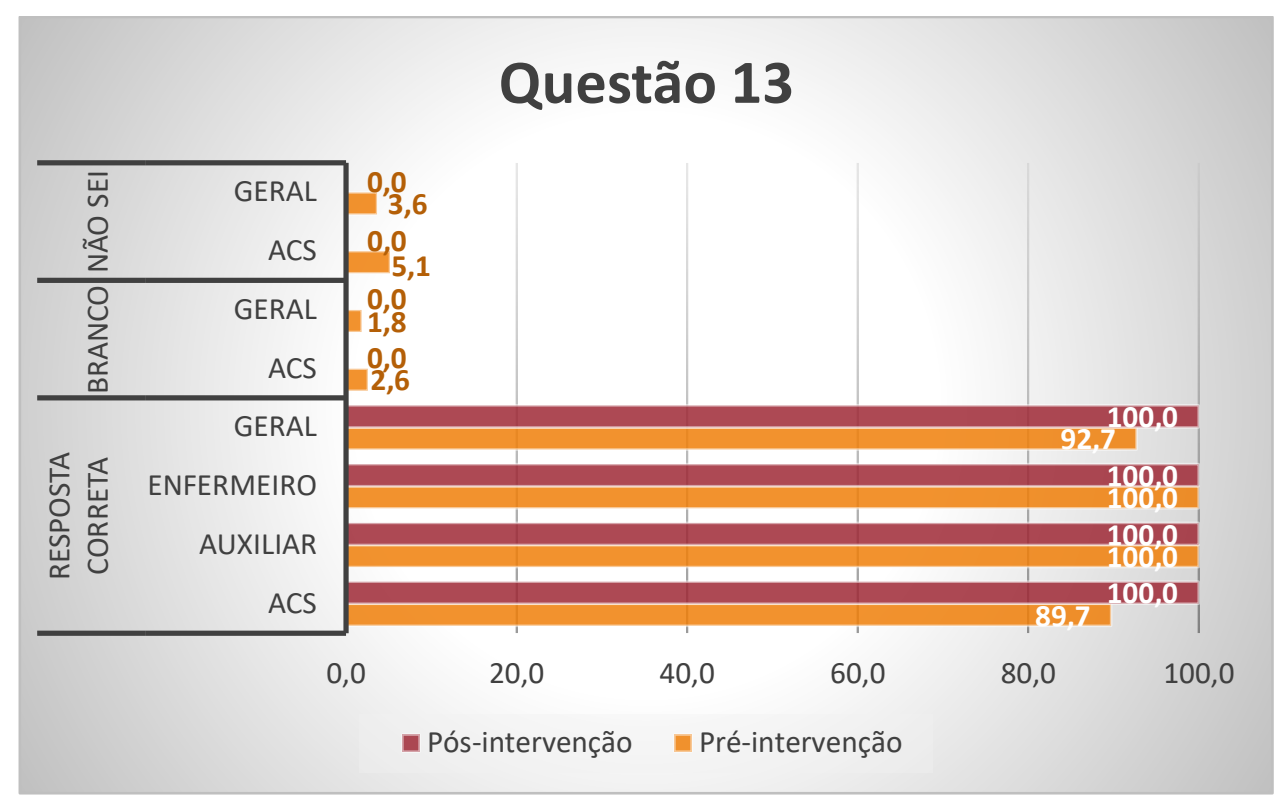

Observa-se que, por ocasião da aplicação do questionário pré-intervenção, 92,7\% dos participantes responderam assertivamente que não avaliar a situação vacinal de uma criança que comparece à unidade de saúde pode gerar uma oportunidade perdida de vacinação, e que houve incremento deste percentual para $100 \%$ dos participantes, após a intervenção. Foi observada alteração para a categoria de ACS, em que, no questionário pré-intervenção, 89,7\% responderam de forma assertiva, e 100,0\% o fizeram após a intervenção. Nesta categoria, 5,1\% dos profissionais responderam "Não sei" para esta questão e 2,6\% deixaram de respondela na pré-intervenção, e nenhum destes profissionais assinalou esta resposta após a ação educativa. Nas categorias enfermeiro e auxiliar de enfermagem este conhecimento já estava presente para 100,0\% desses profissionais, mantendo-se após a intervenção. 
Gráfico 18. Índice de acertos dos participantes sobre vacinação simultânea em crianças com vacina em atraso, questão 14. São Paulo, 2019.

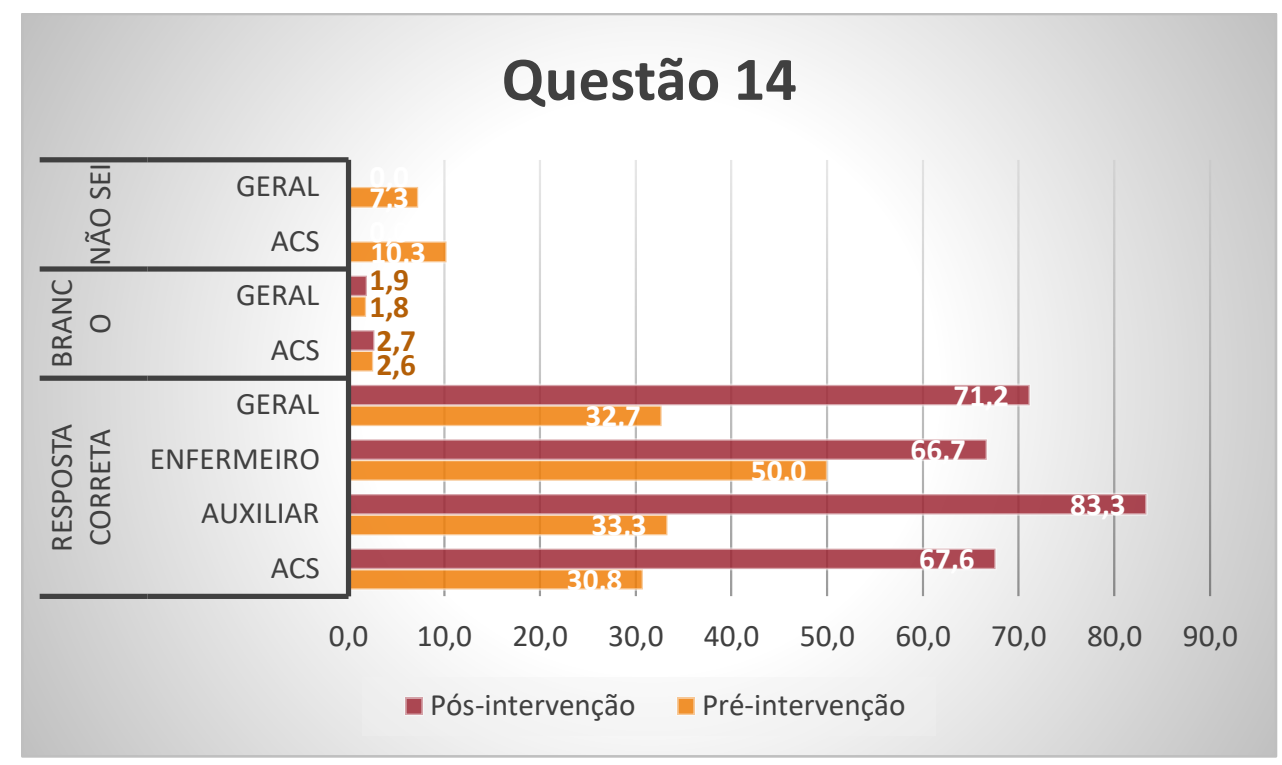

Observa-se que, na pré-intervenção, 32,7\% dos participantes responderam assertivamente que as crianças podem receber todas as vacinas em atraso simultaneamente, e que houve incremento deste percentual para $71,2 \%$ dos participantes, após a intervenção. A maior alteração foi observada na categoria de auxiliares de enfermagem, em que no questionário pré-intervenção, 33,3\% responderam de forma assertiva e 83,3\% o fizeram após a intervenção. Na categoria de ACS, 10,3\% dos profissionais responderam "Não sei" para esta questão no questionário pré-intervenção, e nenhum destes profissionais assinalou esta resposta após a ação educativa. Deixaram de respondê-la, 2,6\% desses profissionais no questionário pré-intervenção, e 2,7\% após a ação educativa. 
Gráfico 19. Índice de acertos dos participantes sobre a importância do registro correto das vacinas aplicadas para o acompanhamento da situação vacinal, questão 15. São Paulo, 2019.

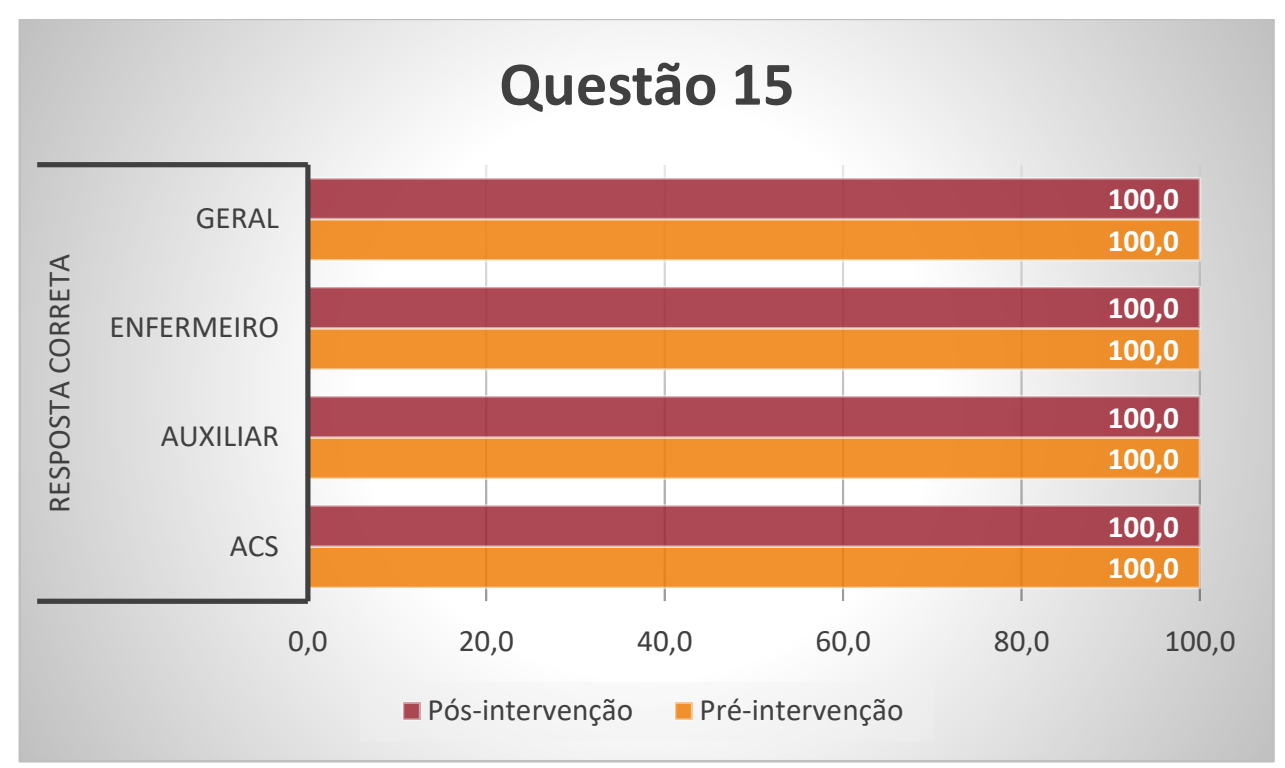

Todos os participantes responderam assertivamente a esta questão, apontando ciência e sensibilização quanto à importância do registro correto das vacinas aplicadas para acompanhamento da situação vacinal.

Gráfico 20. Índice de acertos dos participantes sobre o aumento do risco de transmissão de doenças imunopreveníveis associado a não vacinação de crianças, questão 16. São Paulo, 2019.

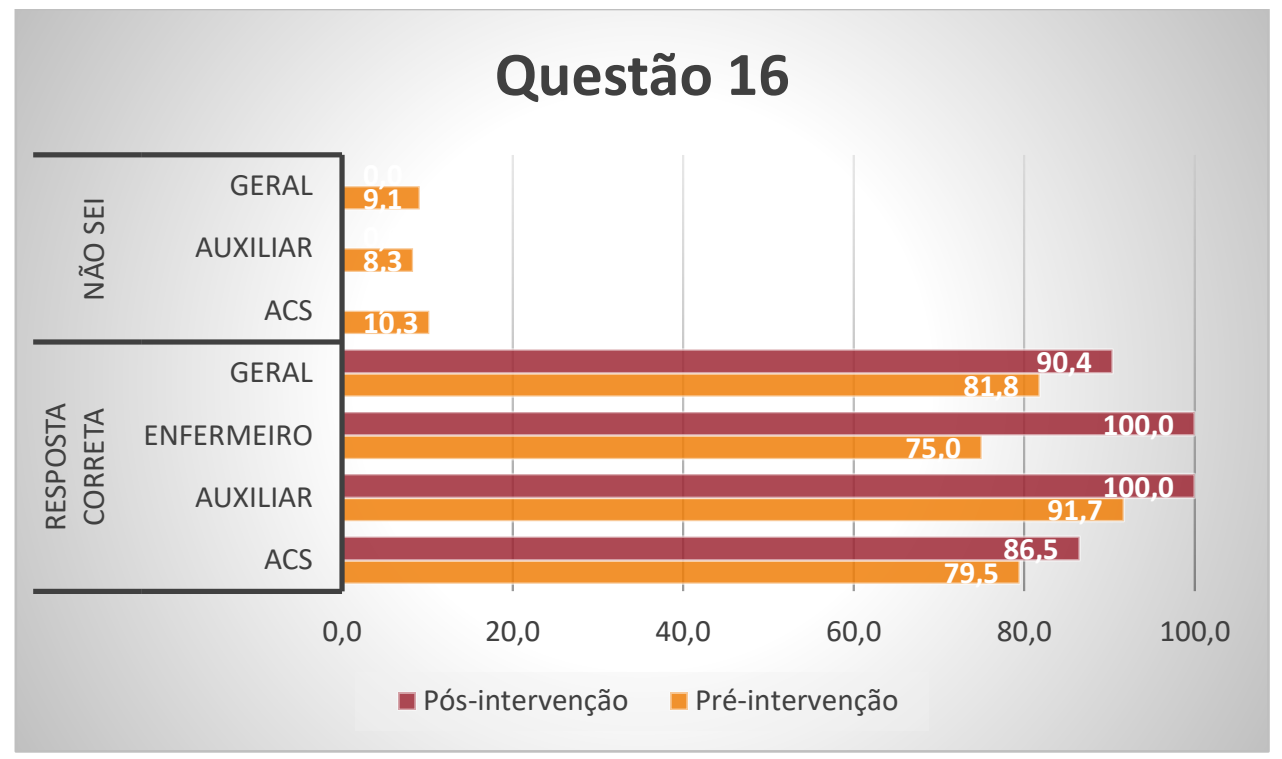


Por ocasião da aplicação do questionário pré-intervenção, $81,8 \%$ dos participantes responderam assertivamente que não permitir a vacinação de uma criança aumenta o risco de outras crianças adquirirem uma doença inunoprevenível, com incremento deste percentual para $90,4 \%$ dos participantes, após a intervenção. A maior alteração foi observada para a categoria de enfermeiros, em que no questionário pré-intervenção $75,0 \%$ responderam de forma assertiva e 100\% o fizeram após a intervenção. Nas categorias auxiliar de enfermagem e de ACS, 8,3\% e 10,3\% dos profissionais, respectivamente, responderam "Não sei" para esta questão no questionário pré-intervenção, e nenhum destes profissionais assinalou esta resposta após a ação educativa.

Gráfico 21. Índice de acertos dos participantes sobre o benefício às crianças com contraindicação a determinadas vacinas através da vacinação de crianças que podem ser vacinadas, questão 17. São Paulo, 2019.

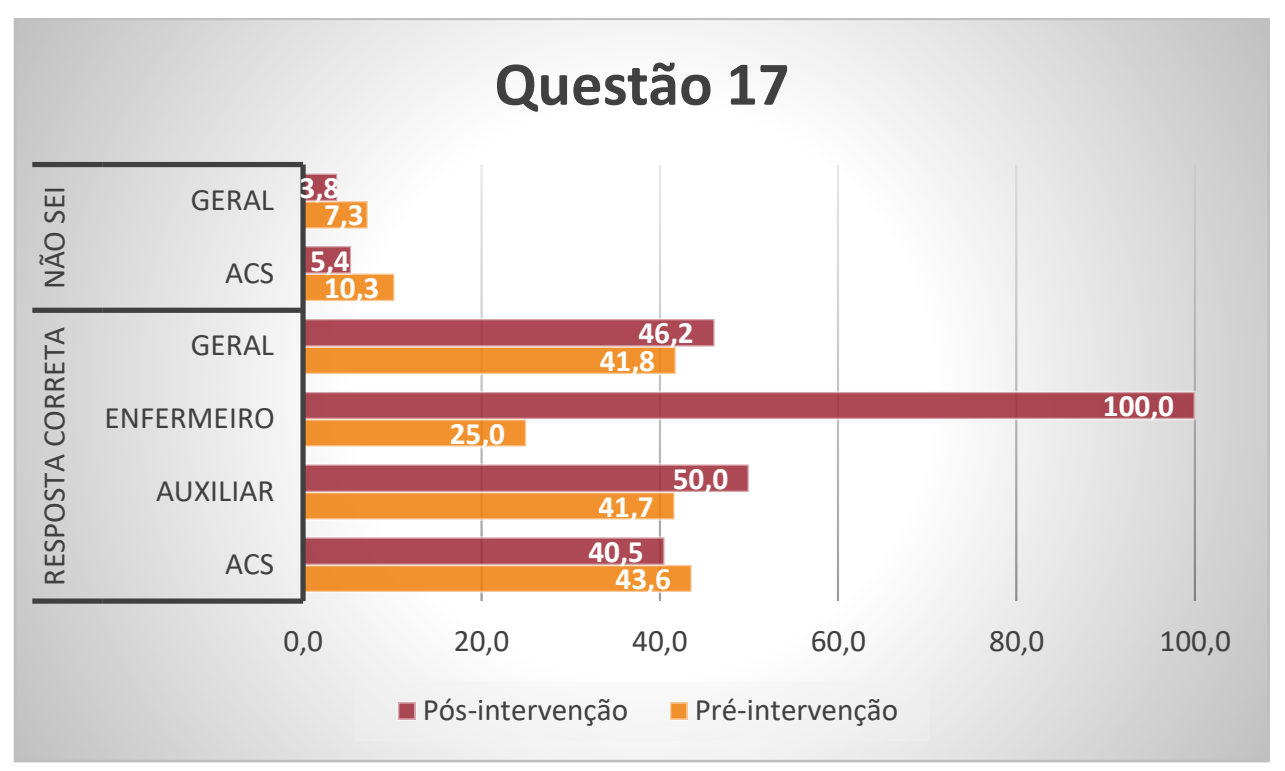

Quando da aplicação do questionário pré-intervenção, 41,8\% dos participantes responderam assertivamente que crianças com contraindicação a determinadas vacinas são beneficiadas através da vacinação de crianças que podem ser vacinadas. Houve incremento deste percentual para $46,2 \%$ dos participantes, após a intervenção. A maior alteração foi observada para a categoria de enfermeiros, em que no questionário pré-intervenção $25,0 \%$ responderam de forma assertiva e $100 \%$ o fizeram após a intervenção. Houve diminuição no percentual de resposta assertiva para a categoria de ACS. Ainda nessa categoria, 10,3\% dos profissionais 
responderam "Não sei” para esta questão no questionário pré-intervenção, e 5,4\% desses profissionais assinalaram esta resposta após a ação educativa.

Gráfico 22. Índice de acertos dos participantes sobre a reintrodução de doenças imunopreveníveis associada à recusa da vacinação, questão 18. São Paulo, 2019.

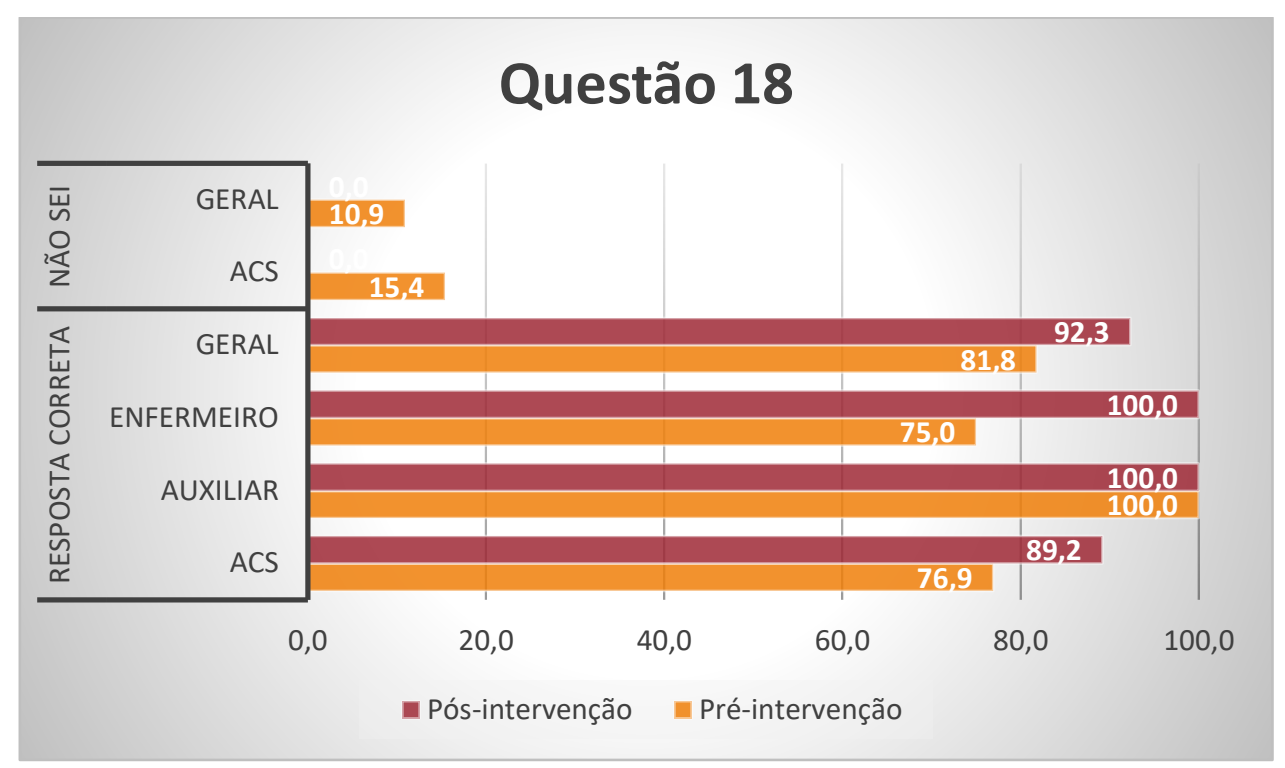

Observa-se que $81,8 \%$ dos participantes responderam assertivamente que recusar a vacinação das crianças pode fazer com que doenças erradicadas sejam reintroduzidas, no questionário pré-intervenção, e que houve incremento deste percentual para 92,3\% dos participantes, após a intervenção. A maior alteração foi observada para a categoria de enfermeiros, em que, no questionário pré-intervenção, $75,0 \%$ responderam de forma assertiva e 100\% o fizeram após a intervenção. $\mathrm{Na}$ categoria ACS, 15,4\% dos profissionais responderam "Não sei" para esta questão no questionário pré-intervenção, e nenhum destes profissionais assinalou esta resposta após a ação educativa. 
Gráfico 23. Índice de acertos dos participantes sobre a associação da falta de acolhimento dos profissionais ao não cumprimento do calendário vacinal, questão 19. São Paulo, 2019.

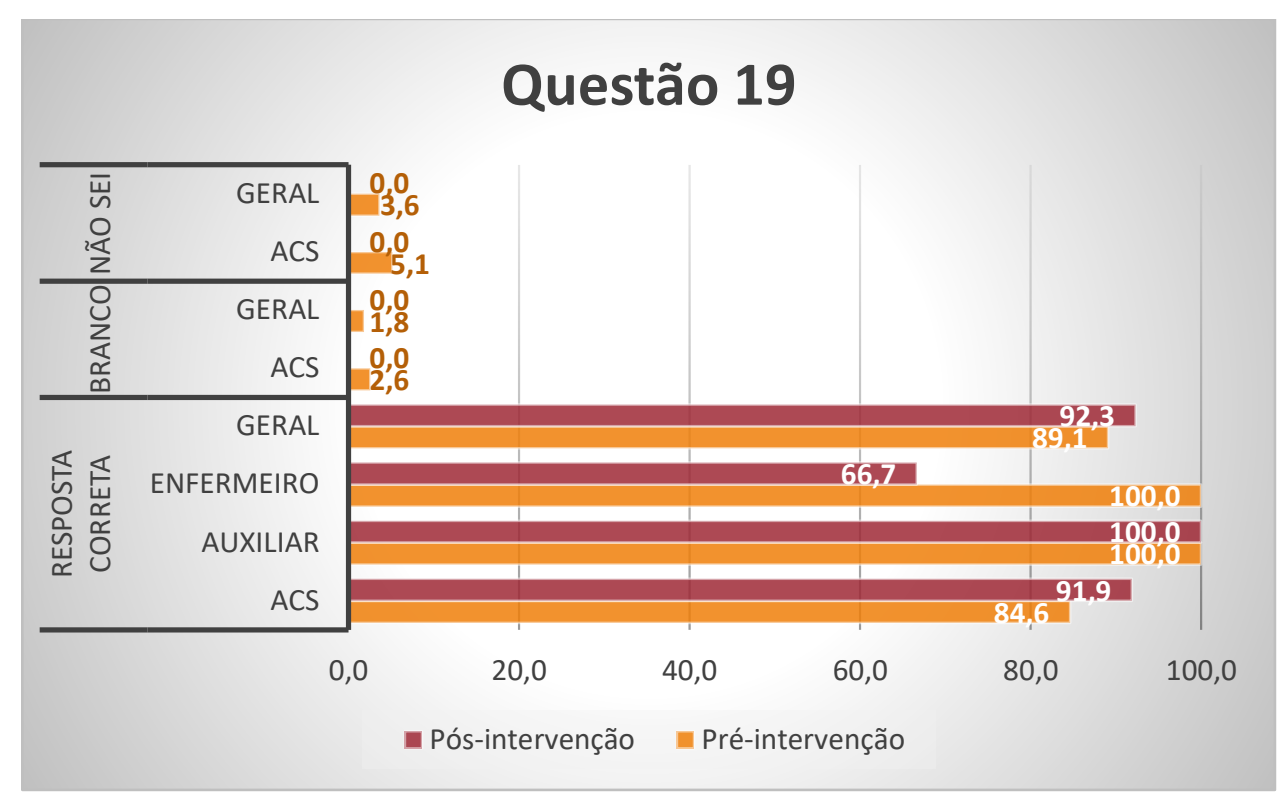

No momento pré-intervenção, $89,1 \%$ dos participantes afirmaram que a falta de acolhimento dos profissionais no serviço de saúde atrapalha o cumprimento do calendário vacinal, verificando-se incremento deste percentual para $92,3 \%$ dos participantes, após a intervenção. Foi observada alteração na categoria de ACS, em que, no questionário pré-intervenção, 84,6\% responderam de forma assertiva e 91,9\% o fizeram após a intervenção, porém houve diminuição da frequência desta resposta assertiva na categoria de enfermeiros. Na categoria de ACS, $5,1 \%$ dos profissionais responderam "Não sei" para esta questão e 2,6\% deixaram de responde-la, no questionário pré-intervenção e, após a ação educativa, todos responderam "Sim" ou "Não". 
Gráfico 24. Índice de acertos dos participantes sobre a associação de reações vacinais anteriores à vacinação futura, questão 20. São Paulo, 2019.

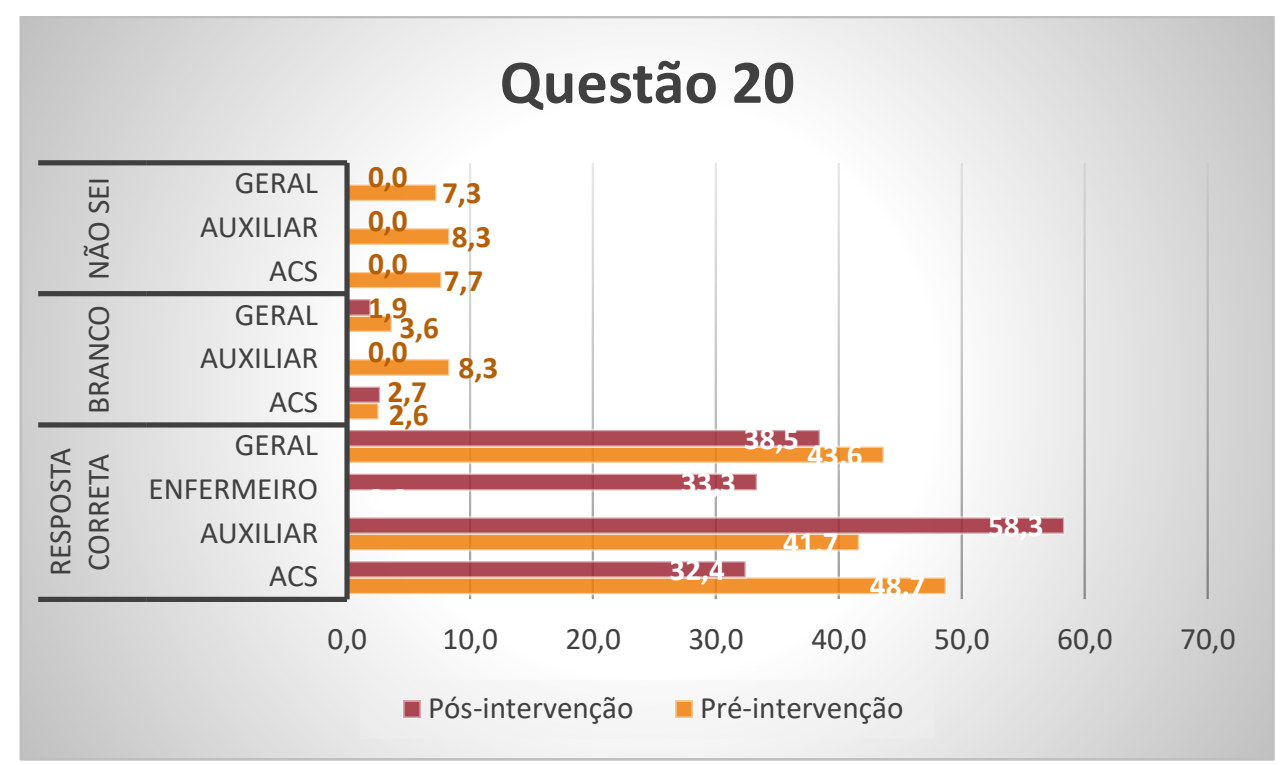

Observa-se que, no momento pré-intervenção, 43,6\% dos participantes afirmaram que reações vacinais anteriores podem atrapalhar na vacinação futura, porém houve diminuição da frequência desta resposta assertiva de maneira geral, e para a categoria de ACS. Entretanto, houve aumento desta frequência nas categorias enfermeiro e de auxiliares de enfermagem, por ocasião da aplicação do questionário pós-intervenção. Responderam "Não sei" para esta questão, 8,3\% dos profissionais da categoria de auxiliares de enfermagem e 7,7\% dos profissionais da categoria de ACS e $8,3 \%$ e $2,6 \%$ dos profissionais destas categorias, respectivamente, deixaram de responde-la, no questionário pré-intervenção, e 2,7\% dos ACS deixaram de reponde-la após a intervenção.

A diminuição da frequência de respostas assertivas para esta questão de maneira geral e na categoria ACS, pode estar associada ao fato de não ter sido especificado na questão se a associação das reações adversas seria em relação às doses posteriores da mesma vacina, ou em relação a vacinas diferentes. Desta forma, infere-se que a questão, da forma como se apresenta, pode induzir a dúvidas nas respostas. 
Gráfico 25. Índice de acertos dos participantes sobre crença quanto a não efetividade de proteção das vacinas e consequente não vacinação, questão 21. São Paulo, 2019.

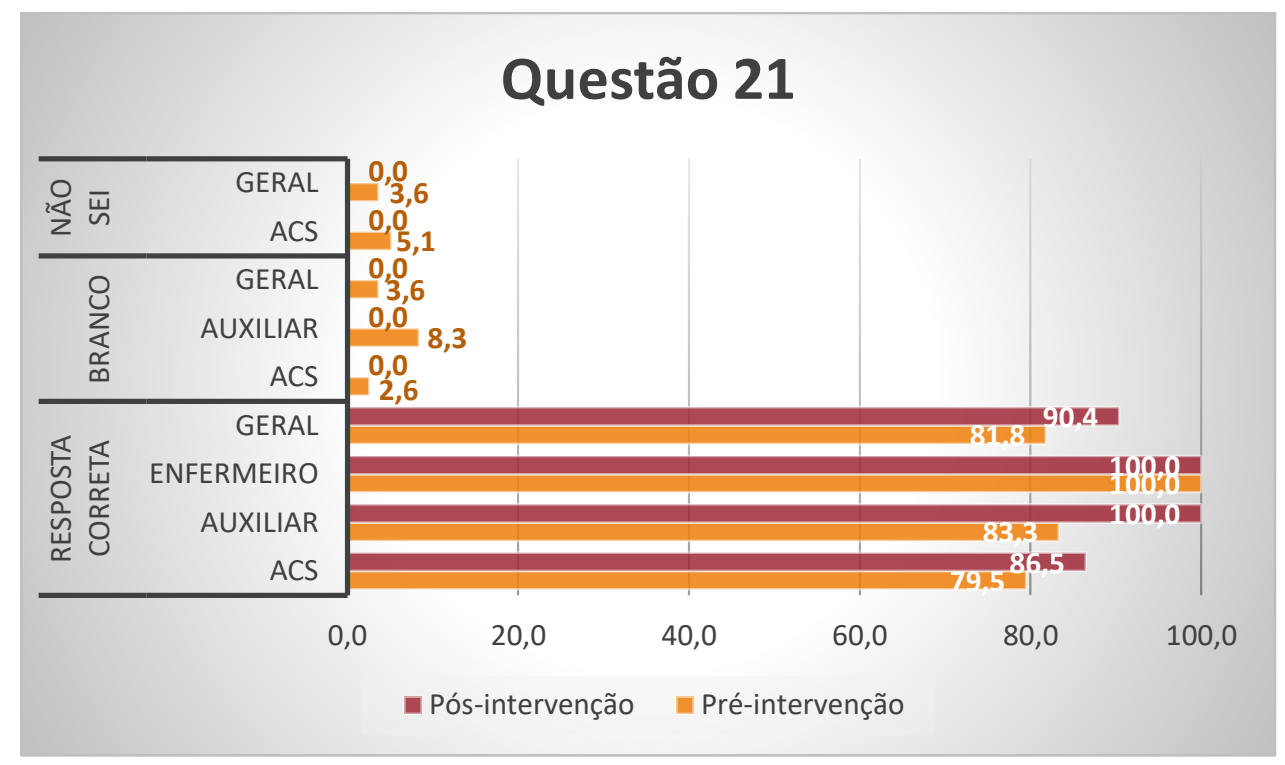

Observa-se que $81,8 \%$ dos participantes afirmaram que a crença quanto a não efetividade de proteção das vacinas pode ocasionar em não vacinação, no questionário pré-intervenção, e que houve incremento deste percentual para 90,4\% dos participantes, após a intervenção. A maior alteração percebida foi para categoria de auxiliares de enfermagem, em que, no questionário pré-intervenção, 83,3\% responderam de forma assertiva e 100,0\% o fizeram após a intervenção. Na categoria de ACS, 2,6\% dos profissionais responderam "Não sei" para esta questão no questionário pré-intervenção, e nenhum destes profissionais assinalou esta resposta após a ação educativa. Deixaram de responde-la, 8,3\% e 2,6\% dos profissionais das categorias de auxiliares de enfermagem e de ACS, respectivamente, e todos a responderam após a intervenção. 
Gráfico 26. Índice de acertos dos participantes sobre o controle de qualidade das vacinas aplicadas no SUS, questão 22. São Paulo, 2019.

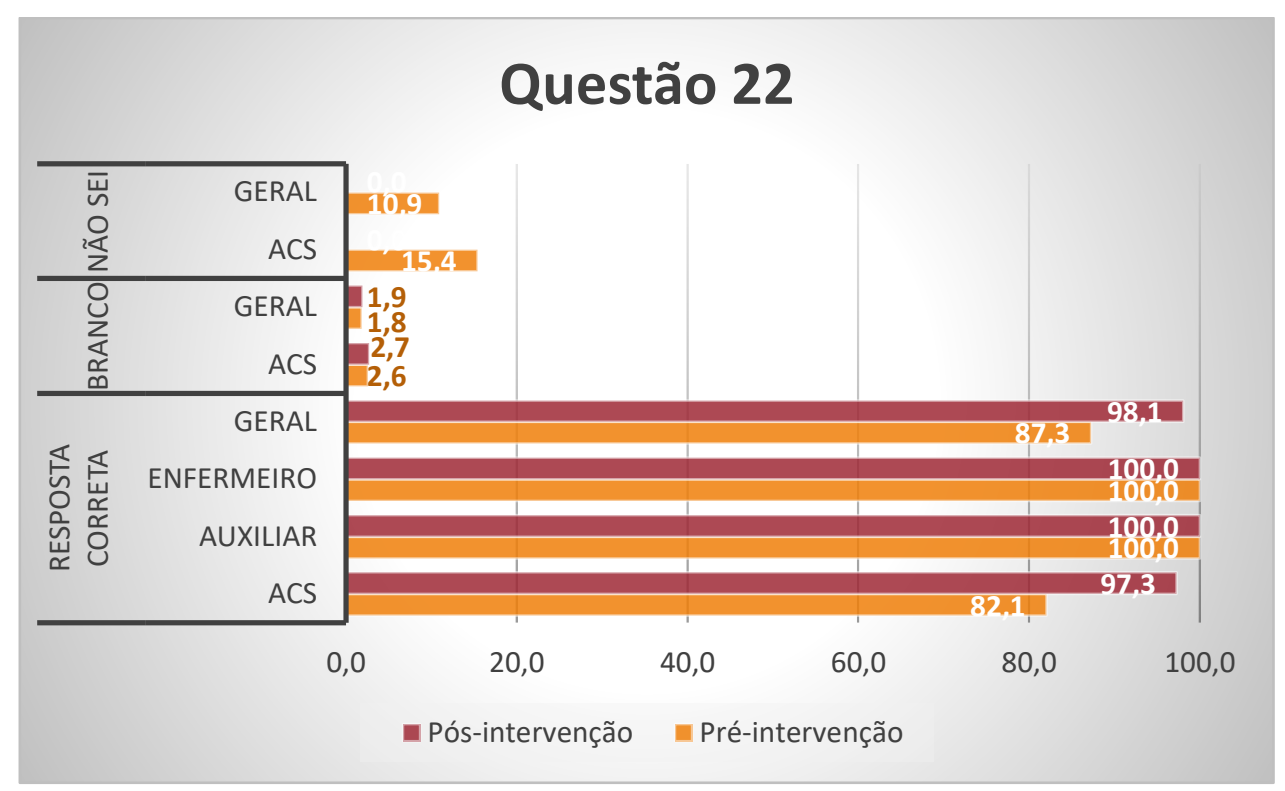

Cerca de $87,3 \%$ dos participantes responderam assertivamente que existe controle de qualidade das vacinas aplicadas no SUS, por ocasião da aplicação do questionário pré-intervenção, e que houve incremento deste percentual para 98,1\% dos participantes, após a intervenção. Foi observada alteração para a categoria de ACS, em que, no questionário pré-intervenção, $82,1 \%$ responderam de forma assertiva e $97,3 \%$ o fizeram após a intervenção. Também nessa categoria de trabalhadores, 15,4\% responderam "Não sei" para esta questão e 2,6\% deixaram de responde-la, no questionário pré-intervenção, e, após a ação educativa, todos responderam "Sim" ou "Não". Nas categorias de enfermeiro e de auxiliares de enfermagem, $100 \%$ dos profissionais demonstraram conhecimento prévio sobre essa questão, mantendo-o após a ação educativa. 
Gráfico 27. Índice de acertos dos participantes sobre o desenvolvimento de imunidade após vacinação, questão 23. São Paulo, 2019.

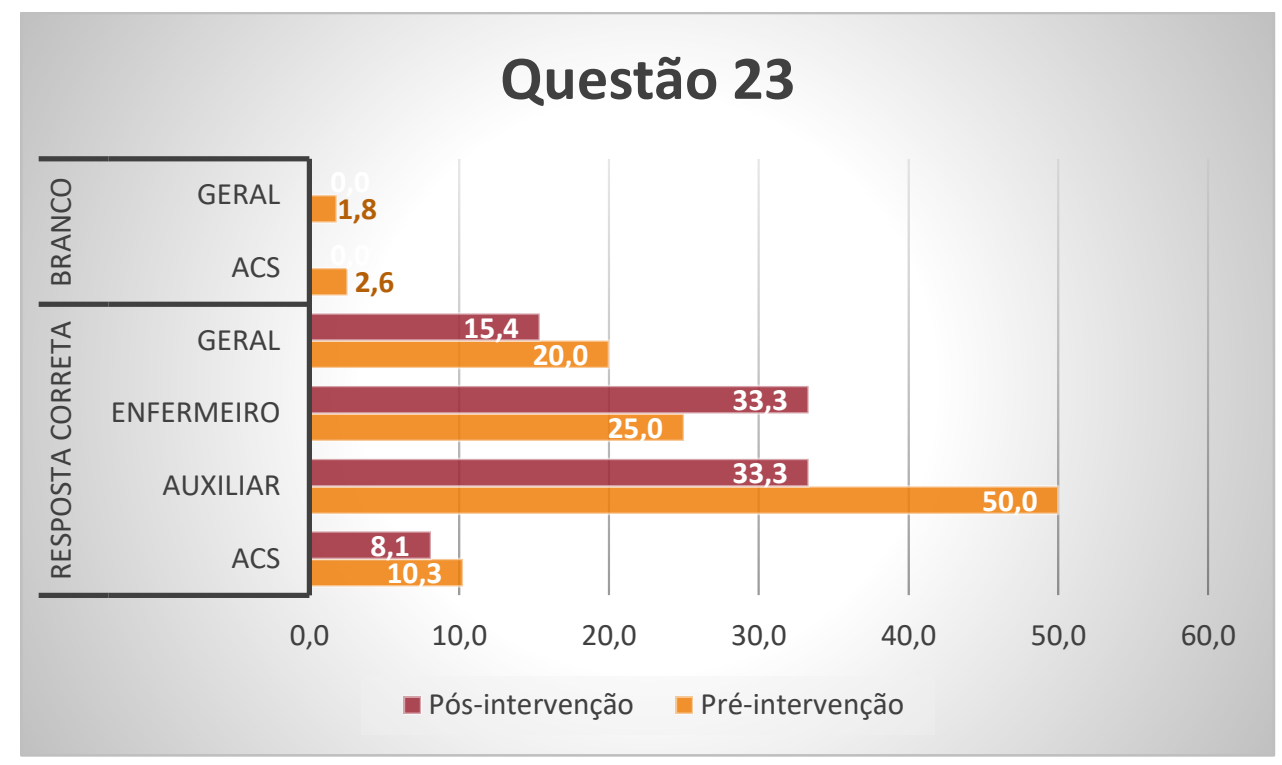

Observa-se, no questionário pré-intervenção, que 20,0\% dos participantes negaram que todas as pessoas vacinadas desenvolvem imunidade contra a doença contra a qual receberam vacina. Porém houve diminuição da frequência desta resposta assertiva de maneira geral, e nas categorias de auxiliares de enfermagem e de ACS, e aumento desta frequência na categoria enfermeiro, no questionário pósintervenção. Deixaram de responde-la $2,6 \%$ dos ACS, no questionário préintervenção, e todos responderam após a intervenção

A diminuição da frequência de respostas assertivas para esta questão de maneira geral e nas categorias de auxiliares de enfermagem e de ACS, pode estar associada ao fato de que durante a ação educativa foi abordado sobre imunologia das vacinas, porém não foi especificado que alguns indivíduos podem não desenvolver imunidade adequadamente, em situações específicas. 
Tabela 3. Número de acertos, relação da vacina com a doença contra a qual protege, questão 24. São Paulo, 2019.

\begin{tabular}{|c|l|c|c|c|c|}
\hline \multirow{2}{*}{ Categoria } & Momento & Mínima & Máxima & Média & Mediana \\
\hline \multirow{2}{*}{ ACS } & Pré-intervenção & 0 & 9 & 5,82 & 6 \\
\cline { 2 - 7 } & Pós-intervenção & 1 & 9 & 6,38 & 7 \\
\hline \multirow{2}{*}{ Auxiliar } & Pré-intervenção & 4 & 9 & 8,41 & 9 \\
\cline { 2 - 7 } & Pós-intervenção & 3 & 9 & 8,41 & 9 \\
\hline \multirow{2}{*}{ Enfermeiro } & Pré-intervenção & 7 & 9 & 8,5 & 9 \\
\cline { 2 - 7 } & Pós-intervenção & 9 & 9 & 9 & 9 \\
\hline
\end{tabular}

Observa-se que o mínimo de acertos obtidos ao relacionar as vacinas contra as doenças contra as quais protegem foi na categoria de ACS, no questionário pré-intervenção. Apesar de que o aumento deste valor tenha sido pequeno, a média de acertos aumentou de 5,82 para 6,38 nesta categoria, e a mediana de 6 para 7 .

$\mathrm{Na}$ categoria de auxiliares de enfermagem, houve aumento de 01 ponto na nota mínima, porém sem alteração da média e da mediana. Na categoria de enfermeiros, houve aumento de 02 pontos na nota mínima, e de 8,5 para 9,0 pontos de média.

Em todas as categorias, houveram profissionais que relacionaram corretamente todas as vacinas contra as doenças contra as quais protegem.

Gráfico 28. Índice de acertos dos participantes nas questões objetivas 3 a 23. São Paulo, 2019.

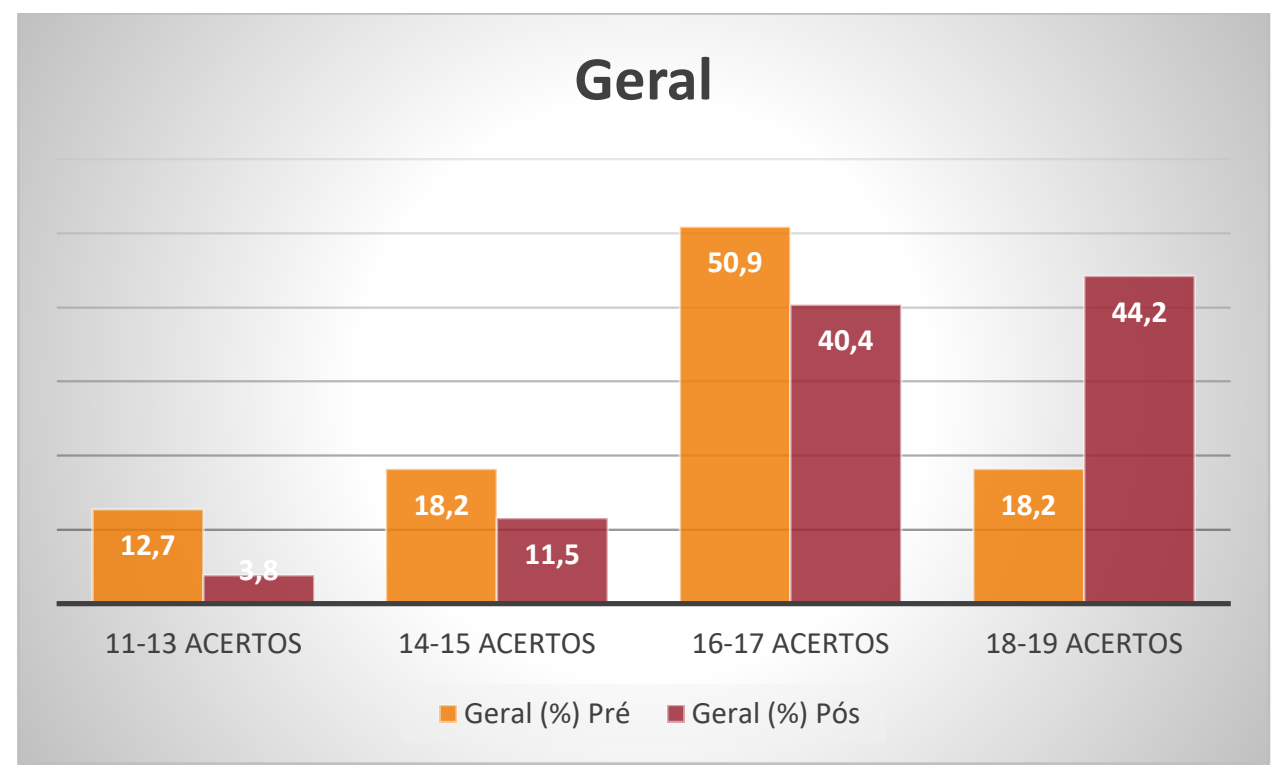


Gráfico 29. Índice de acertos categoria ACS nas questões objetivas 3 a 23. São Paulo, 2019.

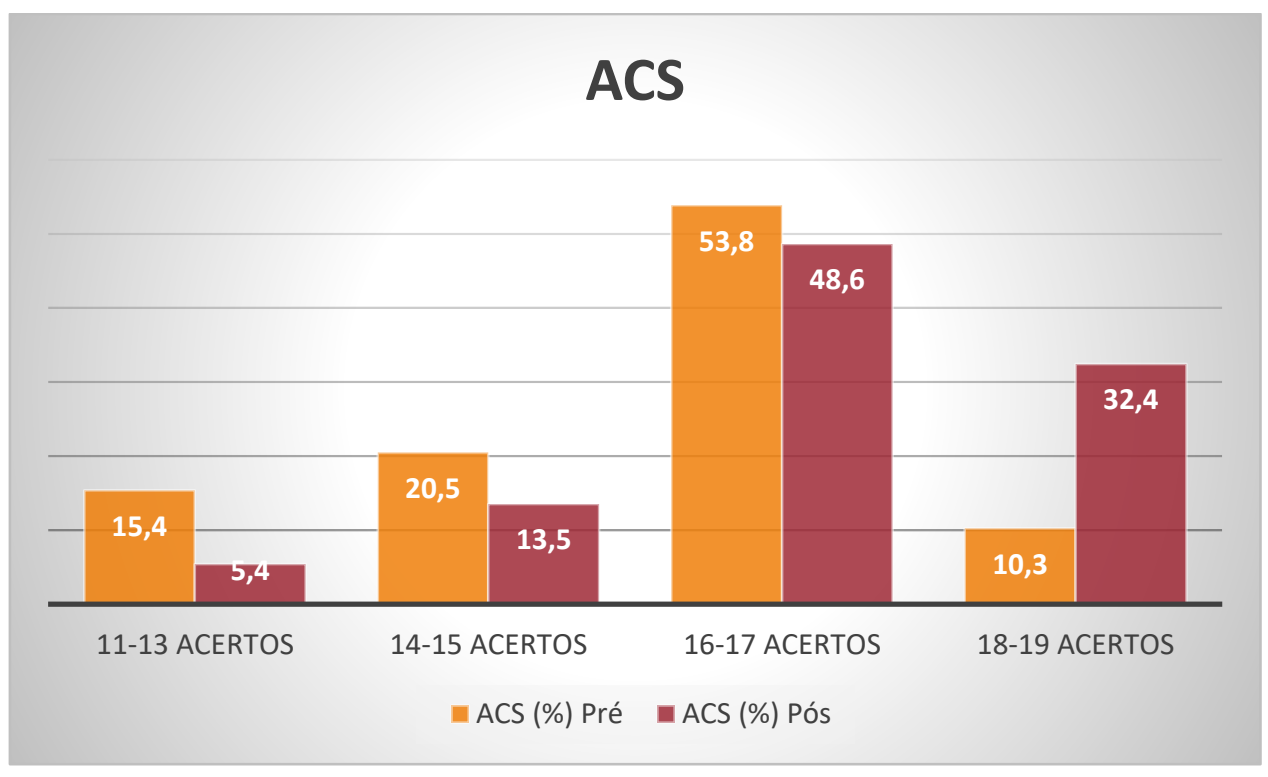

Gráfico 30. Índice de acertos categoria Auxiliar nas questões objetivas 3 a 23. São Paulo, 2019.

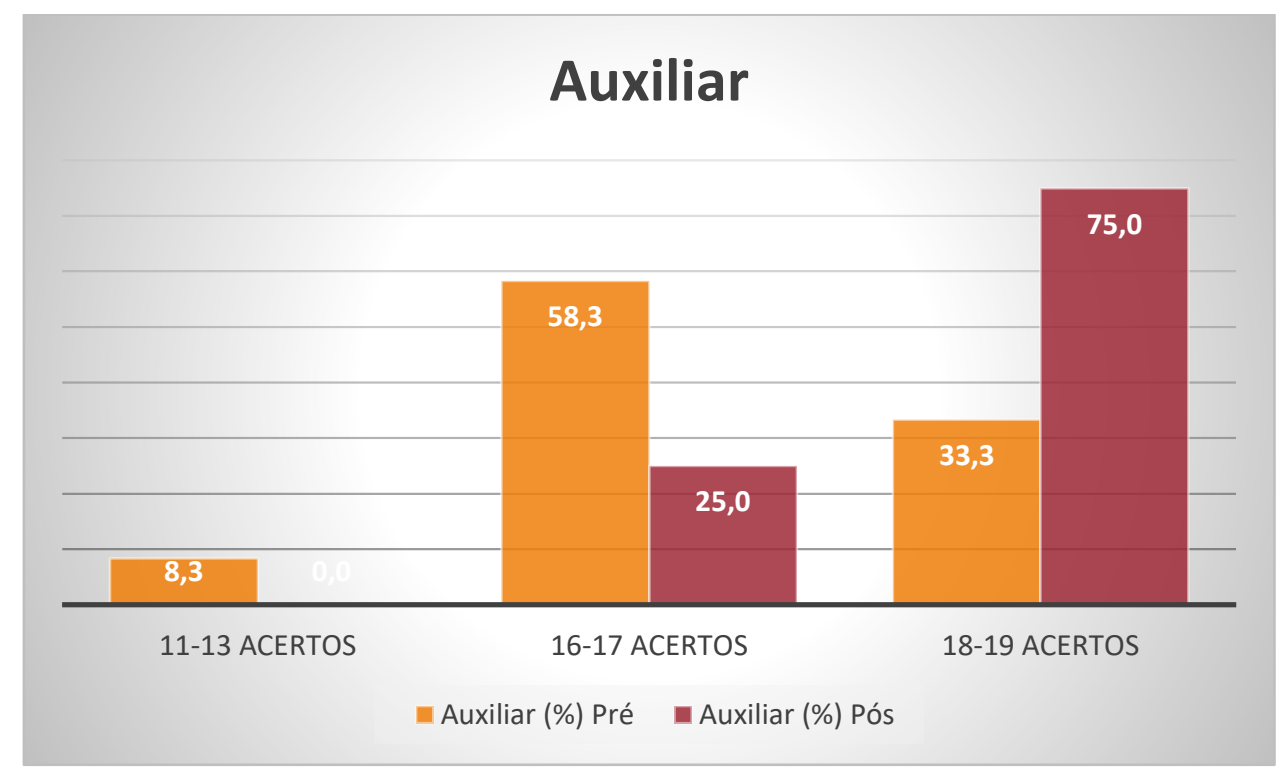


Gráfico 31. Índice de acertos categoria Enfermeiro nas questões objetivas 3 a 23. São Paulo, 2019.

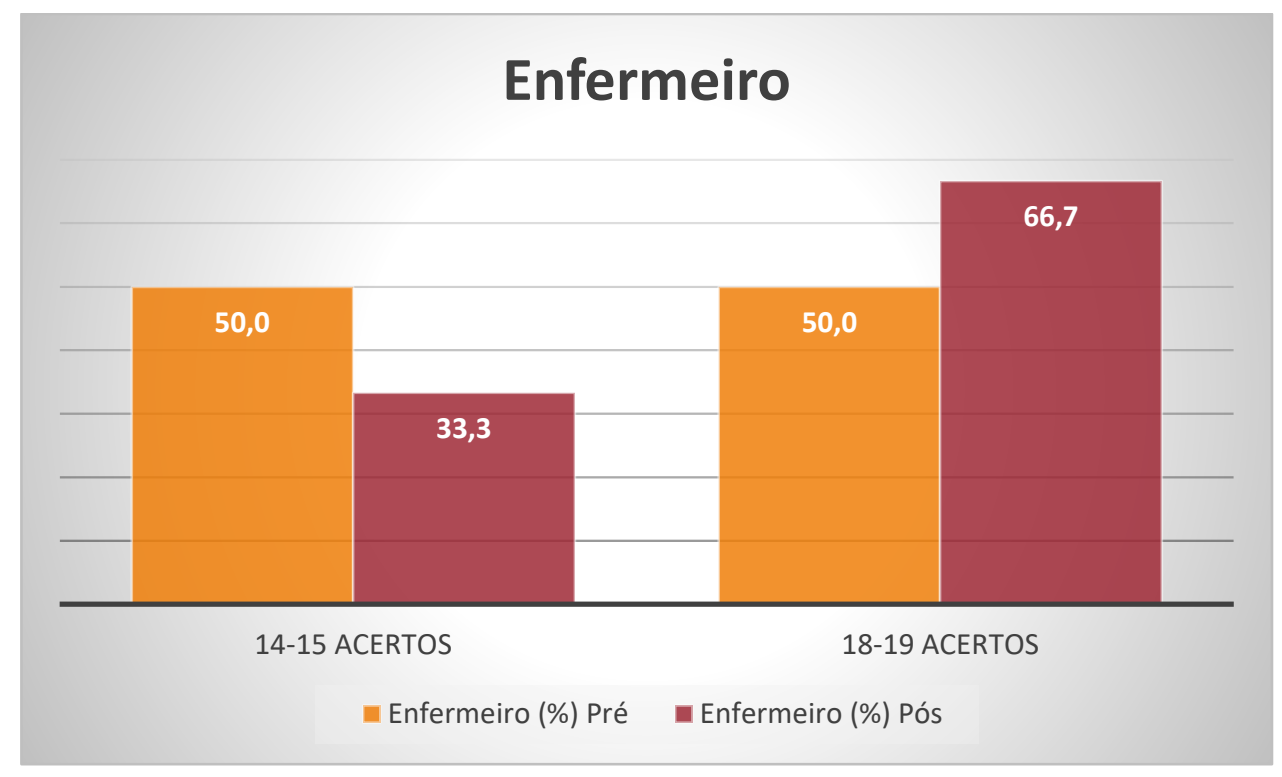

Tabela 4. Média, mínima e medidas de tendência centrais, em relação aos acertos dos participantes nas questões objetivas, questões 3 a 23.

\begin{tabular}{|c|c|c|c|c|c|c|}
\hline \multirow{2}{*}{ Categoria } & Momento & Mínima & Máxima & \multicolumn{1}{c|}{ Média } & Mediana & Moda \\
\hline \multirow{2}{*}{ ACS } & Pré & 11 & 18 & 15,4 & 16 & 16 \\
\hline \multirow{2}{*}{ Auxiliar } & Pós & 11 & 19 & 16,5 & 17 & 17 \\
\hline & Pré & 13 & 19 & 16,8 & 17 & 17 \\
\hline \multirow{2}{*}{ Enfermeiro } & Pós & 17 & 19 & 18,1 & 18 & 18 \\
\hline & Pré & 14 & 18 & 16,2 & 16,5 & 18 \\
\hline \multirow{2}{*}{ Geral } & Pós & 15 & 19 & 17,3 & 18 & - \\
\hline & Pré & 11 & 19 & 15,8 & 16 & 16 \\
\hline
\end{tabular}




\section{DISCUSSÃO}

Mira (2010) discorre sobre o modelo de avaliação de Kirkpatrick, que tem como objetivo avaliar de maneira completa a eficácia de treinamentos. Destacamos um de seus níveis de análise, que é a Avaliação de Aprendizagem, que compara o conhecimento antes e depois de uma ação educativa. Para este fim, podem ser utilizados testes de conhecimentos nestes dois momentos. A autora destaca ainda que fatores como a motivação pessoal e o estágio de desenvolvimento sócio-físicoemocional interferem diretamente na aprendizagem, e que, na maioria das análises, estes não são avaliados para este fim.

Otrenti (2011) ressalta o modelo andragógico de ensino-aprendizagem que teoriza a forma de aprender dos adultos, e que está diretamente ligado ao processo de ensino, que deve considerar a necessidade que o próprio adulto identifica em si em relação ao aprendizado de determinada temática, conhecimentos e experiências prévias à ação educativa, a prontidão do adulto para aprender - que é proporcional ao entendimento em relação aos benefícios que podem advir do aprendizado, a orientação quanto à aplicabilidade dos conteúdos aprendidos, a motivação do adulto para aprender, além da necessidade da corresponsabilização do aprendizado. Diante disso, ressalta, também, que é fundamental a avaliação de necessidades de treinamento.

Segundo Mira (2010), durante o planejamento de um treinamento, é importante escolha adequada do horário em que o mesmo será realizado, devido a possíveis preocupações com escala de trabalho, ou cansaço do profissional. $\mathrm{Na}$ ação realizada no presente estudo, o primeiro grupo teve treinamento marcado para iniciar às 10:00h e o segundo grupo às 14:00h, a fim de manter a cobertura dos setores de enfermagem da UBS e abranger a agenda das enfermeiras. Porém, a ação da manhã iniciou-se às 10:20h e foi concluída às 12:50h, e foi possível perceber que os profissionais estavam cansados, chegando a mostrar-se dispersos durante a intervenção educativa, além de responder ao questionário mais rapidamente do que seria razoável. No período da tarde, a ação iniciou-se às $14 \mathrm{~h} 20$ e foi concluída às 16:35h, ultrapassando, até mesmo, o horário de saída de alguns profissionais. 0 mesmo comportamento observado no período da manhã foi evidenciado nos profissionais que participaram da intervenção nesse período. Ressalta-se também, a 
dimensão extensa do conteúdo abordado, o que pôde ter tornado o treinamento extenuante para os profissionais. Esse fator se evidenciou pelas observações de alguns participantes após o término da ação, relatando que haviam gostado da "aula", que consideravam o tema importante, mas que o mesmo devia ser dividido e abordado com mais tempo posteriormente.

Mira (2010) analisou a avaliação de aprendizagem em dois pontos, sendo um deles a eficácia do treinamento, ou seja, quanto ele favoreceu o aumento do conhecimento do participante, e, o outro, a validade do instrumento.

No presente estudo, observa-se que na categoria ACS, em que não é exigida nenhuma formação específica para saúde, $28 \%$ dos participantes possuíam ensino técnico completo ou incompleto na área da saúde, o que demonstra que os mesmos têm intenção em permanecer na área visando crescimento profissional. Para estes profissionais, o treinamento pode ter causado maior interesse, devido à incorporação de novos conhecimentos que os mesmos poderão utilizar também em novas funções que pretendem alcançar. Observou-se também que $41 \%$ dos auxiliares de enfermagem já possuíam graduação na área da saúde completa ou em curso, o que demonstra que estes também apresentam formação qualificada na área da saúde, além da exigida para as atividades que exercem na UBS em que trabalham. Destacamos aqui a importância de capacitar profissionais de saúde de diversas categorias profissionais, uma vez que, qualificando-os regularmente, estes estarão mais habilitados a cumprir novas funções, de maior responsabilidade, relacionadas às imunizações.

Em relação às questões $1 \mathrm{e} 2$, que abordam os temas das contraindicações e adiamentos das vacinas, destacamos que, para os participantes, os conceitos de contraindicação e adiamento se confundem, uma vez que muitas vezes, o mesmo profissional apontou a mesma situação para as duas questões. A febre é uma situação em que se indica o adiamento da vacinação, porém houveram participantes que referiram que contraindicam a vacina nesta condição. Destacamos, ainda que todas as categorias referiram contraindicar vacinas em situações em que a criança poderia receber o imunobiológico.

Algumas contraindicações citadas pelos participantes, foram citadas de forma genérica, e, desta forma, não foi possível concluir se se tratam de falsas ou verdadeiras, como são os casos de "questões de saúde que impossibilitem a criança de ser vacinada" e "contraindicação médica" - que podem estar relacionadas às 
imunossupressões ou outras situações que, de fato, contraindicam a vacinação. As falsas contraindicações encontradas no pré-teste foram: "doença na criança", "intervalo entre uma vacina e outra" e "pós-operatório", sendo estas referidas pela categoria ACS. Ressaltamos que durante o treinamento os profissionais foram informados de que a maioria das doenças não é contraindicação a vacinação, e que apenas entre as vacinas de vírus/bactéria viva ou entre doses da mesma vacina há necessidade de intervalo mínimo, mas que, ainda assim, não seria uma contraindicação, e sim orientação de adiar alguma vacina que se enquadre nesses critérios.

No pós-teste, foram encontradas as seguintes falsas contraindicações: "convulsão" e "choro intenso na criança após dose anterior". Em relação à vacina Pentavalente, caso a criança apresente doença neurológica em atividade ou tenha apresentado convulsões nas primeiras $72 \mathrm{~h}$ após a vacina, a mesma está contraindicada, porém, essa condição não foi especificada na resposta dos participantes. Também foram elencados os fatores "uso de imunossupressor", "tratamento de câncer" e "transplante" como contraindicações, mas que, na realidade, são apenas situações de adiamento.

Sobre a orientação dada à população sobre o adiamento da vacinação, destacamos que foram apontados adequadamente os fatores "febre" e "uso de corticoide", no pré-teste, e, estas mesmas situações, acrescidas de "vômito, nos casos das vacinas orais", "neoplasia", "transplante", e adiamentos relacionados a vacinas específicas como "diarreia" em vacinas orais, "convulsão" em doses anteriores da Pentavalente, "doenças neurológicas não tratadas" também quanto à Pentavalente, e "amamentação" em relação à vacina da Febre Amarela em mulheres que amamentam bebês menores de 6 meses de idade. Condições como "alergia à componente da vacina", "reação grave à dose anterior" e "reação anafilática a ovo" foram citadas como situações de adiamento, mas seriam, de fato, situações de contraindicação gerais ou específicas.

Destacamos ainda a resposta encontrada na categoria ACS, em que o participante diz que "orienta o responsável pela criança a procurar a UBS em caso de febre ou outras situações", uma vez que o ACS, não estando seguro quanto às orientações a dar às famílias, precisa direcioná-las e reportar as dúvidas à equipe técnica de saúde. Reconhecer os limites do seu próprio conhecimento é de suma importância para que a população não seja orientada equivocadamente. 
De acordo com os resultados obtidos, pode-se questionar se a orientação quanto a essa questão foi feita de forma adequada aos participantes, ou se, seria mais adequado, listar as opções, permitindo aos participantes assinalar as condições que julgassem corretas, ou ainda dividir as situações em aplicáveis a todas as vacinas de maneira geral, vacinas de vírus/bactéria vivos, e situações específicas a determinadas vacinas, como é o caso da Febre Amarela, Influenza, Pentavalente, entre outras.

Verificou-se que a média de acertos no questionário pré-intervenção, para as 21 questões objetivas (questões 3-23), foi de 15,3 pontos para profissionais que nunca haviam realizado treinamento anterior sobre o tema, e 16,7 pontos nos que referiram já ter passado por esta ação previamente, demonstrando que havia diferença de conhecimento inicial sobre o assunto entre esses dois grupos de participantes.

Entre estas questões, o mínimo de acertos no pré e pós-teste foi de 11 pontos, e o máximo de 19, considerando 1 ponto por questão. A média passou de 15,8 para 16,9, a mediana de 16 para 17 e a moda de 17 para 18, respectivamente nos dois momentos. Desta forma, pode-se considerar que houve aumento do conhecimento dos profissionais quanto ao tema proposto.

Constatou-se aumento do conhecimento dos participantes quanto a diminuição da mortalidade infantil associada a maiores coberturas vacinais, não haver riscos que contraindiquem vacinar as crianças de pouca idade, oportunidade perdida de vacinação, possibilidade que as crianças com vacinas em atraso as recebam simultaneamente, aumento do risco de transmissão de doenças imunopreveníveis associado a não vacinação de crianças, benefício às crianças com contraindicação a determinadas vacinas através da vacinação de crianças que podem ser vacinadas, reintrodução de doenças imunopreveníveis associada à recusa da vacinação, existência de um controle de qualidade das vacinas aplicadas no SUS, interferência da crença dos pais ou responsáveis quanto a não importância da vacinação e/ou não efetividade das vacinas na não adesão à vacinação, responsabilidade da equipe de saúde na busca de crianças faltosas e importância do acolhimento dos profissionais no serviço de saúde.

Mira (2010) também refere alto índice de acerto em algumas questões, tanto no momento pré como no pós-intervenção, demonstram conhecimento prévio sobre o tema. 
Neste estudo verificou-se que em duas questões - de número 03 e 15, sendo uma acerca da importância do conhecimento dos pais ou responsáveis pela criança acerca das doenças imunopreveníveis e a outra sobre a importância do registro correto das vacinas aplicadas para acompanhamento da situação vacina, $100 \%$ dos profissionais assinalaram a resposta correta, nos dois momentos. Como não houve avaliação prévia da necessidade do treinamento, o conteúdo da ação abordou tanto temas aparentemente já consolidados pelos participantes, quanto temas mais distantes das suas realidades de trabalho. Aqui é importante reforçar que o treinamento foi realizado igualitariamente para diferentes categorias profissionais, com diversos tempos de trabalho e formações profissionais.

Apontamos que, no presente estudo, houveram resultados não esperados em relação ao comparativo das respostas do pré e do pós-teste, o que será descrito a seguir.

Quanto à questão 4, que versa sobre desenvolvimento da imunidade efetiva após primeira dose de uma vacina, a diminuição da frequência de respostas assertivas para esta questão nas categorias enfermeiro e auxiliar de enfermagem, podem estar associadas ao fato de que na ação educativa foi apresentado que para as vacinas de bactérias / vírus inativas, em geral, é necessário mais de uma dose da vacina para conferir imunidade completa ao indivíduo, porém para algumas vacinas de bactérias / vírus vivo atenuado, é possível desenvolver imunidade completa após uma única dose, como é o caso das vacinas BCG e Febre Amarela. Entretanto, estas condicionais não foram levadas em consideração na formulação da questão, podendo induzir a dúvida no momento da resposta.

Quanto à questão 5, que versa sobre erradicação de uma doença inunoprevenível em uma determinada localização em regiões com alta cobertura vacinal, a diminuição da frequência de respostas assertivas para esta questão na categoria enfermeiro e a manutenção de baixo percentual de respostas assertivas de maneira geral, pode estar associada ao fato de que na questão pergunta-se se "a maior parte das crianças estiver vacinada adequadamente" determinada doença pode deixar de existir. Durante a aplicação do questionário, foi interrogado por um participante sobre o que significaria "a maior parte das crianças" e se em alguns casos a doença poderia ter sua circulação diminuída, mas não ser eliminada. Desta forma, percebe-se que a construção desta questão pode induzir a dúvidas nas respostas, uma vez que não foi explicitado a porcentagem ideal de cobertura vacinal, nem 
considerado a condição de que algumas doenças são eliminadas completamente da circulação em um determinado local com altas taxas de cobertura vacinal, como ocorreu com a Poliomielite, e algumas doenças continuam circulando, com menor incidência e menor gravidade, como observa-se em relação à Influenza - uma vez que a vacina tem o objetivo de prevenir a Síndrome Respiratória Aguda Grave (SRAG), mas permanece a transmissão dos vírus que compõe a vacina.

Quanto à questão 9, que versa sobre a responsabilidade da equipe de saúde quanto à orientação aos pais sobre as vacinas e as doenças imunopreveníveis, no pré-teste todos os participantes haviam acertado a questão, porém houve queda no índice de acertos na categoria enfermeiro, sem possíveis inferências sobre o ocorrido.

Quanto à questão 10, que questiona se seria responsabilidade exclusiva da enfermeira o acompanhamento da situação vacinal das crianças, no pré-teste todos os participantes haviam acertado a questão, porém houve queda no índice de acertos na categoria auxiliar de enfermagem, sem possíveis inferências sobre o ocorrido.

Quanto à questão 12, que versa sobre interferência em não receber as doses de reforço para o esquema vacinal, a diminuição da frequência de respostas assertivas para esta questão em geral e na categoria ACS e a manutenção de baixo percentual de respostas na categoria auxiliar de enfermagem, pode estar associada ao fato de que na questão não foi considerado que há vacinas que não exigem reforço vacinal. Desta forma, percebe-se que a construção desta questão pode ter induzido a dúvidas nas respostas.

Quanto à questão 20, que versa sobre a associação de reações vacinais anteriores à vacinação futura, a diminuição da frequência de respostas assertivas para esta questão de maneira geral e na categoria ACS, pode estar associada ao fato de não ter sido especificado na questão se a associação das reações adversas seriam a doses posteriores da mesma vacina, ou a vacinas diferentes. Desta forma, percebese que a construção desta questão também pode ter induzido a dúvidas nas respostas.

$\mathrm{E}$, quanto à questão 23, que versa sobre o desenvolvimento de imunidade após vacinação, a diminuição da frequência de respostas assertivas para esta questão de maneira geral e nas categorias auxiliar de enfermagem e ACS, pode estar associada ao fato de que durante a ação educativa foi abordado o tema da resposta 
imune induzida pelas vacinas, porém não foi especificado que alguns indivíduos podem não desenvolver imunidade adequada, em situações específicas.

Marinelli, Carvalho e Araújo (2015) realizaram uma revisão integrativa sobre os entraves encontrados na literatura quanto ao conhecimento dos profissionais de enfermagem de sala de vacina. Nos 15 artigos analisados, foi apontada a necessidade de educação continuada para estes profissionais, pois havia sido encontrado conhecimento insuficiente, gerando, entre outras consequências, condutas inadequadas frente a Eventos Adversos Pós-Imunização, limpeza inadequada da câmara de vacina, lacunas nas orientações à clientela, falhas que podem comprometer a qualidade dos imunobiológicos, além de falhas de conhecimento sobre a conservação e acondicionamento das vacinas.

Feitosa e Coriolano (2010) realizaram estudo a respeito do conhecimento de auxiliares de enfermagem sobre vacinação, e verificaram que não há implantação regular de educação permanente para esses profissionais, sobre o tema, o que resulta em orientações equivocadas ou insuficientes desses profissionais aos pais ou responsáveis pelas crianças.

$\mathrm{Na}$ região onde foi realizado o presente estudo, é possível inferir que a maior parte dos treinamentos neste tema está direcionado aos enfermeiros e auxiliares de enfermagem, uma vez que estes atuam mais intimamente com atividades relacionadas a vacinação, e que poucos são os ACS que estão sendo capacitados sobre o tema. Observamos que anualmente é realizada uma "Oficina de Imunização" pela Supervisão Técnica de Saúde da região para os profissionais que atuam nas salas de vacinas das UBS. Em geral, é possível que, nestes treinamentos, participem um enfermeiro e um auxiliar de enfermagem de cada unidade. Os profissionais são selecionados de acordo com sua escala na supervisão da sala de vacina, para enfermeiros, e atuação direta na sala de vacina, para auxiliares. Ressaltamos que essas ações são de suma importância para incrementar o conhecimento destes profissionais, mas que há dificuldades para que os mesmos reproduzam os conteúdos aprendidos a outros profissionais na unidade de saúde, o que mantém a heterogeneidade do nível de conhecimento das diversas categorias de profissionais da saúde.

Ferro (2019) destaca a queda das coberturas vacinais em todo Brasil desde o ano de 2016. Em 2016, a cobertura vacinal geral foi de 50,4\% no Brasil, muito abaixo do recomendado para o controle das doenças imunopreveníveis. Associa as 
coberturas menores no norte e nordeste do país à maior dificuldade de acesso às unidades de saúde e maior percentual de pobreza. Também destaca que as fake news sobre associações de determinadas vacinas a doenças colabora para a diminuição da adesão à vacinação.

Teixeira (2018) aponta para as chamadas fake news relacionadas à imunização, e como estas podem causar a diminuição da cobertura vacinal, além de aumentar a circulação de doenças imunopreveníveis. A autora apresenta o significado de fake news como relatos inventados, falsos, ao se descrever um determinado evento, informações falsas, que mantém aparência de notícia jornalística e são disseminadas por meio de internet e outras mídias. São materiais produzidos com o objetivo de conduzir o leitor a determinado entendimento da realidade, e que são disseminados facilmente pelas redes sociais e aplicativos de trocas de mensagem, podendo causar prejuízos à coletividade. Ressalta que as fake news atuam em favor dos movimentos antivacina no mundo. Destaca que fake news tiveram influência considerável na baixa cobertura vacinal de febre amarela recentemente no Brasil, com informações de que a vacina era perigosa e que as doses fracionadas eram "fracas". Também aponta para a influência desse tipo de informação na cobertura vacinal contra o Sarampo nas Américas, o que se evidencia na queda da cobertura vacinal da vacina SCR de $100 \%$, em 2004, para $85 \%$, em 2017, no Brasil. Não somente a população em geral pode ser influenciada por esse tipo de informações inadequadas, mas também profissionais de saúde que não dispõem de conhecimento suficiente a respeito.

Segue quadro apresentado pela autora que elucida o que anteriormente foi mencionado. 
Figura 3. Cobertura vacinal de determinados imunobiológicos. 2012-2016. São Paulo, 2019.

Coberturas vacinais por tipo de vacinas em crianças menores de 1 ano e 1 ano de idade*

\begin{tabular}{|c|c|c|c|c|c|}
\hline Imunoblologicos & 2012 & 2013 & 2014 & 2015 & 2016 \\
\hline$B C G$ & 105,7 & 107,43 & 107,28 & 105,08 & 95,5 \\
\hline Hepatite $B<$ Imes & NA & NA & 88,54 & 90,93 & 81,66 \\
\hline Rotavirus Humano (<1ano) & 86,37 & 93,32 & 93,44 & 95,35 & 88,97 \\
\hline Meningococo $\mathrm{C}(<1$ ano $)$ & 96,18 & 99,70 & 96,36 & 98,19 & 91,67 \\
\hline Meningococo $\mathrm{C}\left(1^{\circ}\right.$ ref -1 ano) & $\ldots$ & 92,35 & 88,55 & 87,85 & 93,85 \\
\hline Penta (DTP/Hib/HB) < 1ano & 93,80 & 95,89 & 94,85 & 96,30 & 89,26 \\
\hline DTP (1० ref) & $\ldots$ & 90,96 & 86,36 & 85,78 & 64,27 \\
\hline Pneumocócica & 88,39 & 93,57 & 93,45 & 94,23 & 94,98 \\
\hline Pneumococica ( $1^{\circ}$ ref - 1 ano) & $\ldots$ & 93,12 & 87,95 & 88,35 & 84,09 \\
\hline Poliomielite & 96,55 & 100,71 & 96,76 & 98,29 & 84,42 \\
\hline Poliomielite ( $1^{\circ}$ ref -1 ano) & $\ldots$ & 92,92 & 86,31 & 84,52 & 74,33 \\
\hline Hepatite A (1 ano) & $\ldots$ & $\ldots$ & 60,13 & 97,07 & 71,57 \\
\hline Triplice Viral D1 (1 ano) & 99,5 & 107,46 & 112,8 & 96,07 & 95,35 \\
\hline Triplice Viral D2 (1 ano) & $\ldots$ & 68,87 & 92,88 & 79,94 & 76,71 \\
\hline Dupla adulto / dTpa gestante & NA & 50,69 & 43,06 & 42,6 & 33,80 \\
\hline
\end{tabular}

Extraído de: Teixeira (2018).

A mesma autora ressalta que a diminuição na cobertura vacinal é influenciada pela desinformação, que é corroborada pelas fake news. Diante deste cenário, o Ministério da Saúde criou um programa de verificação de notícias falsas para captar e combater esse problema, uma vez que este fato passou a ser um problema de saúde pública.

Teixeira (2018) também salienta o papel em relação à falsidade de informações, e como fundamento de movimentos antivacina, à exemplo do estudo publicado por Wakefield, já citado neste presente trabalho, e do documentário "DPT Vaccine Roulette", de 1982, - que associava a vacina DTP a "inflamações crônicas cerebrais". Também discorre sobre a publicação do livro "The vaccine book: making the right decision for your child", do médico Robert Sears, que minimiza a gravidade de doenças imunopreveníveis e reforça a ideia de recusar ou retardar a vacinação.

No contexto atual, com a maior facilidade de acesso da população às mídias digitais, por exemplo, à rede web, há consequentemente maior possibilidade de acesso às informações, que nem sempre são obtidas de fontes confiáveis, uma 
vez que muitos "sites" veiculam falsas notícias sobre vacinação (alguns financiados por "movimentos antivacina"). É, portanto, necessário que os órgãos centrais de saúde combatam as fake news nas redes sociais e nas mídias digitais de forma clara, didática e atrativa para que a população possa confrontar com as informações não institucionais às quais tem acesso. Difundir falsas informações sobre as doenças imunopreveníveis, riscos associados às vacinas, não necessidade de vacinar as crianças, interesses das indústrias farmacêuticas em faturar com vacinas desnecessárias à população, "invenções" sobre de surtos de doenças pelo governo para induzir pessoas a se vacinarem, é um mal que pode trazer graves consequências à coletividade. De fato, o aumento da circulação de algumas doenças já pode ser visto, associado a estes e outros fatores que diminuem a adesão à vacinação.

Por outro lado, Couto e Barbieri (2015) frisam que há menor cobertura vacinal em crianças de famílias de alta renda e escolaridade. Em seu estudo, realizado no município de São Paulo, os autores comparam casais vacinadores, casais vacinadores tardios ou seletivos e casais não vacinadores das classes sociais $A 1, A 2$, B1 e B2, quanto aos motivos que levam à realização ou não da vacinação.

Quadro 2. Motivos que levam à realização ou não da vacinação. São Paulo, 2019.

\begin{tabular}{|c|c|}
\hline \multicolumn{2}{|c|}{ Motivos que levam à realização ou não da vacinação } \\
\hline Casais vacinadores & $\begin{array}{r}\text { Associam a vacinação como expressão do cuidado dos pais e } \\
\text { sua responsabilidade na proteção das crianças; }\end{array}$ \\
\hline $\begin{array}{c}\text { Casais vacinadores } \\
\text { tardios ou seletivos }\end{array}$ & $\begin{array}{r}\text { Associam a vacinação a uma proteção importante, porém julgam } \\
\text { que as recomendações devem ser singularizadas; }\end{array}$ \\
\hline $\begin{array}{c}\text { Casais não } \\
\text { vacinadores das } \\
\text { classes sociais }\end{array}$ & $\begin{array}{r}\text { Associam a não vacinação como expressão do cuidado dos pais, } \\
\text { por poderem causar riscos à saúde e doenças graves não } \\
\text { estarem mais circulando, e que há outras formas de protegeram } \\
\text { as crianças. }\end{array}$ \\
\hline
\end{tabular}

O estudo descreve justificativas apontadas pelos pais que são vacinadores seletivos ou não vacinadores, para não vacinar as crianças, tais como: doenças eliminadas ou controladas no Brasil, gravidade diminuída das doenças, medo de efeitos adversos, crítica à composição e forma de ação das vacinas no organismo, dúvidas quanto à efetividade e eficácia das vacinas. $\mathrm{O}$ autor discute que, atualmente, 
a disponibilização de informação veiculada pela Internet alterou a forma dos sujeitos se relacionarem com os profissionais de saúde. Também analisa que, após um período com altas taxas de coberturas vacinais, são menos conhecidos pela população as complicações e a letalidade das doenças imunopreveníveis e mais evidentes as reações adversas pós-vacinação, o que gera uma sensação de controle das doenças e "insegurança".

Entende-se que é importante difundir informações corretas sobre as vacinas e reorientar a população sobre os cenários possíveis em caso de reemergência de doenças, até o momento, controladas.

Sato (2018) apresenta um importante conceito que é a hesitação vacinal, que consiste em atraso ou recusa da aceitação das vacinas recomendadas e disponibilizadas no serviço de saúde. Esta hesitação pode ocorrer de maneira total ou parcial em relação às vacinas disponíveis, e é influenciada pela confiança quanto à eficácia e segurança das vacinas, a percepção do risco em contrair a doença que, caso seja baixa, pode gerar o entendimento de que a vacina não é necessária, além da disponibilidade de acesso às vacinas e às informações relacionadas a elas. A autora associa esta ação aos movimentos antivacina, e grifa que as suas consequências são e serão o advento de surtos e epidemias cada vez mais frequentes de doenças imunopreveníveis, como o sarampo, a coqueluche, e a ameaça de reintrodução da poliomielite.

Tauil (2017) relata que as Campanhas Nacionais de Vacinação são estratégias para aumento da cobertura vacinal. Durante o período de epidemia de sarampo, percebe-se que as campanhas vacinais colaboram para a intensificação da vacinação. A procura pela vacina SCR aumentou consideravelmente, com o início do registro de casos e óbitos pela doença e sua divulgação pela mídia. A falsa sensação de segurança em relação a uma doença que já havia sido eliminada no país, deu lugar ao medo e a busca por proteção.

Se faz necessário destacar também que há circulação do poliovírus no continente africano e na região mediterrânea oriental, e também ocorreram casos da doença na Venezuela em 2018, e que o Brasil, sendo um país aberto para entrada de viajantes de todos os lugares do mundo, e que apresenta diminuição da taxa de cobertura vacinal, pode estar suscetível à reintrodução desta doença. Diante disso, levanta-se a urgência para discutir estratégias para aumentar a cobertura vacinal no país, o que pode ser feito, além das ações de educação em saúde e busca ativa de 
faltosos nas salas de vacina, através de amplas campanhas vacinais, dentre outras medidas.

Trabalhar o conhecimento dos profissionais sobre aspectos fundamentais da vacinação, abrangência do calendário vacinal, segurança e controle de qualidade das vacinas, eventos adversos pós-vacinação, situações corretas para contraindicação e adiamento de vacinas, e conhecer as doenças imunopreveníveis e quais poderiam ser as consequências se a população deixasse de se vacinar, assim como reforçar a importância e responsabilidade dos profissionais das equipes de saúde como atores que protagonizam a propagação de informações sobre o tema, é essencial para que o profissional de saúde esteja apto a orientar a população com clareza, e ter ações assertivas que colaborem para o aumento da adesão à vacinação, e consequentemente, da cobertura vacinal.

É essencial investir em ações de Educação Permanente, de forma que não sejam realizados apenas ações educativas eventuais que são determinadas pelas instituições de saúde, mas que antes, partam da problematização do trabalho, reconhecendo os trabalhadores como atores reflexivos da prática e construtores de conhecimento, a fim de que estes se sintam valorizados, e capazes de articular novos conhecimentos às ações cotidianas. Também é importante ressignificar o que é ser um profissional de saúde que atua na APS, pois este trabalho exige alta disponibilidade psíquica e emocional para lidar com o outro. As altas cargas de trabalho, os baixos salários, a instabilidade no emprego, metas instituídas verticalmente e que não visam a atenção específica aos problemas encontrados pelos profissionais em sua região de atuação geram "stress" e uma série de agravos à saúde mental. A falta de insumos de saúde, o lidar diário com a vulnerabilidade social elevada, associada à baixa renda e a baixa escolaridade da população, também são elementos que trazem desmotivação e ansiedade aos profissionais de saúde, podendo gerar "indiferença" a essas questões a longo prazo, e apatia frente aos desafios encontrados. Conforme já citado neste trabalho, desde a implantação da ESF, foram observados indicadores que comprovavam o incremento significativo nas coberturas vacinais, sendo assim, é preciso restaurar para as equipe de saúde as condições necessárias para que as coberturas vacinais voltem a alcançar patamares próximos a cobertura requerida e necessária para 0 controle das doenças imunopreveníveis e consequentemente com a melhora das condições de vida da população. 
Também é importante que os profissionais estejam cientes sobre quais são as fake news que têm sido semeadas de forma ampla nos meios midiáticos, redes sociais e aplicativos de troca de mensagens, para diferenciá-las das verdadeiras informações e combate-las nos momentos de encontro com os usuários.

Outro ponto importante a destacar é o acolhimento dos profissionais, pois é preciso que se desenvolva uma postura de aproximação aos usuários, para que esses se sintam amparados para esclarecer dúvidas, medos, crenças e conceitos préexistentes sobre as imunizações, sem que se sintam jugados ou pressionados para cumprir o calendário vacinal apenas por uma imposição da instituição de saúde, e sim, que o façam entendendo os benefícios atribuídos a esta ação.

É fundamental que se criem espaços de discussão sobre saúde entre os profissionais e a população, para incremento do conhecimento sobre os temas de saúde, particularmente em relação aos que abrangem a promoção à saúde e a imunização e que se intensifique as ações realizadas no território para educação em saúde da comunidade, e que se utilizem de todas as oportunidades para incentivar a imunização e desconstruir falsos conceitos que comprometem a saúde da população. 


\section{CONCLUSÕES}

Este estudo aponta um déficit de conhecimento sobre imunizações nos profissionais da ESF, que são os principais atores na educação em saúde da população. Esta lacuna está presente tanto na categoria de Agentes Comunitários de Saúde, quanto na de Auxiliares de Enfermagem e na de Enfermeiros.

Ainda que o estudo tenha apresentado limitações, já descritas, como alto conteúdo temático para um período curto e ininterrupto de treinamento, e questões com formulação inadequada para os fins desejados, é possível afirmar que houve incremento do conhecimento dos profissionais acerca do tema proposto, principalmente em se tratando dos ACS.

Ressaltamos que o cenário epidemiológico brasileiro, com reintrodução ou aumento da circulação de algumas doenças, tais como a Febre Amarela e o Sarampo, demonstram que há lacunas na cobertura vacinal, e que é responsabilidade da Atenção Primária à Saúde fornecer à população dados que a fortaleçam no sentido de compreender a importância das vacinas, negar falsas contraindicações à imunização, combater movimentos antivacina e aumentar a adesão à vacinação.

Destacamos que há necessidade de ações de educação permanente sobre o tema nas Unidades Básicas de Saúde, abrangendo todas as categorias da ESF, incluindo médicos, que também transmitem informações sobre imunizações durante consultas de puericultura, pré-natal e visitas domiciliares.

Propomos a adequação do instrumento de coleta de dados, do material utilizado para o treinamento e do planejamento adequado deste, a fim de melhorar a avaliação de aprendizagem desta ação, e reproduzi-la em outros cenários. 


\section{REFERÊNCIAS}

Andrade DRS, Lorenzini E, Silva EF. Conhecimento de mães sobre o calendário de vacinação e fatores que levam ao atraso vacinal infantil. Cogitare Enferm. 2014;19(1)94-100.

Andrus JK, Bandyopadhyay AS, Danovaro-Holliday MC, Dietz V, Domingues C, Figueroa JP, et al. El pasado, el presente y el futuro de la inmunización en las Américas. Rev Panam Salud Publica, 2017. [citado2018 set. 15]. Disponível em: http://iris.paho.org/xmlui/bitstream/handle/123456789/34394/v41e1212017_spa.pdf? sequence $=6$ \&isAllowed $=y$

Barros MGM, Santos MCS, Bertolini RPT, Netto VBP, Andrade MS. Perda de oportunidade de vacinação: aspectos relacionados à atuação da atenção primária em Recife, Pernambuco, 2012. Epidemiol. serv. Saúde. 2015; 24(4):701-10.

Bellesi N. Oportunidades Perdidas. Online Rev Para Med [Internet]. 2007 [citado 2014 Set. 30];21(2). Disponível em: http://scielo.iec.pa.gov.br/scielo.php?script=sci arttext\&pid=S0101$\underline{59072007000200014 \& \operatorname{lng}=\text { pt. }}$

Biblioteca Virtual em Saúde, Rede Internacional de Informações para Saúde (RIPSA) [Internet]. Brasília; 2012. [atualizado 2016; citado 2016 jan. 17]. Disponível em: http://fichas.ripsa.org.br/2012/category/cobertura/?l=pt_BR.

Bordim MCH. Avaliação do Desempenho do PNI (Programa Nacional de Imunização) no Estado de São Paulo no ano de 2011 no cumprimento do esquema básico de imunização [dissertação]. São Paulo: Faculdade de Ciências Médicas da Santa Casa de São Paulo;2013.

Brasil. Constituição, 1988. Constituição da República Federativa do Brasil. Brasília: Senado; 1988.

Brasil. Lei n. 6.259, de 30 de outubro de 1975. Dispõe sobre a organização das ações de Vigilância Epidemiológica, sobre o Programa Nacional de Imunizações, estabelece normas relativas à notificação compulsória de doenças, e dá outras providências. Diário Oficial da União, Brasília, 31 out. 1975.

Brasil. Lei n. 8.080, de 19 de setembro de 1990. Dispõe sobre as condições para a promoção, proteção e recuperação da saúde, a organização e o funcionamento dos serviços correspondentes e dá outras providências. Diário Oficial da União, Brasília, 20 set. 1990.

Brasil. Ministério da Saúde, Secretaria de Atenção à Saúde, Departamento de Atenção Básica.sșẹp trabalho do agente comunitário de saúde. Brasília; 2009. 
Brasil. Ministério da Saúde, Secretaria de Gestão do Trabalho e da Educação na Saúde, Departamento de Gestão da Educação em Saúde. Politica Nacional de Educação Permanente em Saúde. Brasília; 2009.

Brasil. Ministério da Saúde, Secretaria de Vigilância em Saúde. Doença Diarreica por Rotavírus: Vigilância Epidemiológica e Prevenção pela Vacina Oral de Rotavírus Humano. Brasília; 2005.

Brasil. Ministério da Saúde, Secretaria de Vigilância em Saúde. Programa Nacional de Imunizações. Programa Nacional de Imunizações: 30 anos. Brasília; 2003.

Brasil. Ministério da Saúde, Secretaria de Vigilância em Saúde, Departamento de Vigilância das Doenças Transmissíveis, Coordenação-Geral do Programa Nacional de Imunizações. Manual de Normas e Procedimentos para Vacinação. Brasília; 2014.

Brasil. Ministério da Saúde, Secretaria de Vigilância em Saúde, Departamento de Vigilância Epidemiológica. Doenças infecciosas e parasitárias: guia de bolso. Brasília; 2010.

Brasil. Ministério da Saúde, Secretaria de Vigilância em Saúde. Programa de qualificação das ações de vigilância em saúde: Fichas de qualificação dos indicadores. Brasília; 2013.

Brasil. Ministério da Saúde. Secretaria de Vigilância em Saúde. Vigilância Epidemiológica do Sarampo no Brasil 2019: Semanas Epidemiológicas 28 a 39 de 2019. Boletim Epidemiológico.(50): 28.

Bujes MK. Motivos do atraso vacinal em crianças e estratégias utilizadas para amenizar o problema - uma pesquisa bibliográfica [monografia]. Porto Alegre: Faculdade de Medicina, Universidade Federal do Rio Grande do Sul; 2012.

Cardoso IM. Rodas de Educação Permanente da Atenção Básica de Saúde: analisando contribuições. Saúde Soc. 2012;21(1)18-28.

Cardoso MDT, Carneiro SG, Ribeiro TT, Strapasson JF, Carneiro RG. Avaliação da cobertura vacinal em crianças de 2 meses a 5 anos na Estratégia Saúde da Família. Rev. APS. 2015;18(3):273-80.

Costa NMN, Leão AMM . Casos notificados de eventos adversos pós-vacinação: contribuição para o cuidar em enfermagem. Rev Enferm UERJ. 2015; 23(3):297-303.

Couto MT, Barbieri CLA. Cuidar e (não) vacinar no contexto de famílias de alta renda e escolaridade em São Paulo, SP, Brasil. Ciênc. saúde coletiva. 2015;(20)1:105-14. DOI: 10.1590/1413-81232014201.21952013.

Cruz MGB. PSF - Programa de Saúde da Família - Comparando a mortalidade infantil, cobertura vacinal e hospitalizações estre municípios com e sem o programa no estado de São Paulo [dissertação]. São Paulo: Faculdade de Saúde Pública da Universidade de São Paulo;2002. 
Domingues CMAS, Teixeira AMS. Coberturas vacinais e doenças imunopreveníveis no Brasil no período 1982-2012: avanços e desafios do Programa Nacional de Imunizações. Epidemiol. serv. saúde [Internet]. 2013 [citado 2016 mar. 04];19(3):14753. Disponível em: http://scielo.iec.pa.gov.br/scielo.php?pid=S167949742013000100002\&script=sci_arttext.

Faria LS. As práticas de vigilância na supervisão técnica de saúde do Butantã - São Paulo (SP): perspectivas para o alcance da vigilância à saúde [dissertação]. São Paulo: Escola de Enfermagem, Universidade de São Paulo; 2007.

Feitosa LR; Feitosa JA; Coriolano MWL. Conhecimentos e práticas do auxiliar de enfermagem em sala de imunização. Cogitare Enfermagem. 2010;(15): 695-701

Fernandes ACN, Gomes KRO, Araújo TME, Moreira-Araújo RSR. Análise da situação vacinal de crianças pré-escolares em Teresina (PI). Rev. Bras. Epidemiol. 2015;18(4):870-82.

Ferreira AV, Freitas PHB, Viegas SMF, Oliveira VC. Acesso à sala de vacinas da Estratégia Saúde da Família: aspectos organizacionais. Rev Enferm UFPE. 2017; 11(10):3869-77.

Ferro MRC, Caldas RS, A TRAJETÓRIA DA COBERTURA VACINAL NO BRASIL E A INFLUÊNCIA DAS FAKE NEWS. TCC. Aracaju, 2019.

Fiocruz, Instituto Tecnologia em Imunobiológicos Bio-Manguinhos [Internet]. Rio de Janeiro; s.d. [atualizado 2014; citado 2016 mar. 04]. Disponível em: https://www.bio.fiocruz.br/index.php/doenca-pneumococica-sintomas-transmissao-eprevencao

Fitzpatrick M. The Cutter Incident: How America's First Polio Vaccine Led to a Growing Vaccine Crisis. J R Soc Med. 2006;99(3):156.[citado 2018 se. 15]. Disponível em: https://www.ncbi.nlm.nih.gov/pmc/articles/PMC1383764/

Fracolli LA, Faria LS, Pereira JG, Melchior R, Bertolozzi MR. Vigilância à Saúde: deve se constituir como política pública?. Saúde Soc. 2008;17(2):184-92. DOI: 10.1590/S0104-12902008000200017.

Guimarães TMR, Alves JGB, Tavar MMF. Impacto das ações de imunização pelo PSF. Cad. Saúde Pública. 2009;25(4):868-876.

Henrique F. Diagnóstico comunitário da área de abrangência da unidade de saúde da Prainha - Florianópolis - Santa Catarina. Rev. APS Juiz de Fora. 2010;13(4):456-64.

Levi GC. Recusa de vacinas: causas e consequências. São Paulo: Segmento Farma, 2013.

Luhm KR, Cardoso MRA, Waldman EA. Cobertura vacinal em menores de dois anos a partir de registro informatizado de imunização em Curitiba, PR. Rev. saúde pública [Internet]. 2011 [citado 2016 mar. 04];45(1):90-8. Disponível em: http://www.scielo.br/pdf/rsp/2010nahead/1768.pdf 
Marinelli NP, Carvaho KM, Araujo TME. Conhecimento dos profissionais de enfermagem em sala de vacina: análise da produção científica. Revista Univap. 2015; (21)38.

Mira VL. Avaliação de programas de treinamento e desenvolvimento da equipe de enfermagem de dois hospitais do município de São Paulo [tese]. São Paulo, Escola de Enfermagem da Universidade de São Paulo, 2010.

Moraes JC, Ribeiro MCSA, Simões O, Castro PC, Barata RB. Qual é a cobertura vacinal real? Epidemiol. serv. Saúde [Internet]. 2003 [citado 2016 mar. 04];12(3):14753. Disponível em: http://scielo.iec.pa.gov.br/scielo.php?pid=S167949742003000300005\&script=sci_arttext.

Nóbrega AA, Teixeira AMS, Lanzieri TM. Avaliação do Sistema de Informação do Programa de Imunizações (SI-API). Cad. saúde colet., (Rio J.). 2010;18(1):145-53.

Oliveira VC, Rennó HMS, Santos YR, et al. Educação para o trabalho em sala de vacina: percepção dos profissionais de enfermagem 2016;6(3):2331-41. DOI: 10.19175/recom.v6i3.1180.

Otrenti E. Avaliação de processos educativos formais para profissionais da área da saúde: revisão integrativa da literatura [dissertação]. São Paulo, Escola de Enfermagem da Universidade de São Paulo, 2011.

Paulo EF. Oportunidades perdidas de vacinação em crianças menores de dois anos de idade, ocorridas nas salas de vacinação, das unidades de saúde da região norte do município de São Paulo [dissertação]. São Paulo: Programa de Pós-Graduação em Ciências da Coordenadoria de Controle de Doenças da Secretaria de Estado da Saúde de São Paulo; 2010.

Peduzzi M, Del Guerra DA, Braga CP, Lucena FS, Silva JAM. Atividades educativas de trabalhadores na atenção primária: concepções de educação permanente e de educação continuada em saúde presentes no cotidiano de Unidades Básicas de Saúde em São Paulo. Interface comun. saúde educ. 2009;13(30):121-34.

Pinto AAM, Fracolli LA. O trabalho do agente comunitário de saúde na perspectiva da promoção da saúde: considerações práxicas. Rev. eletr. enf. [Internet]. 2010[citado 2017 dez.26];12(4):766-9. Disponível em: http://dx.doi.org/10.5216/ree.v12i4.7270

Plotkin SA. Vaccines: past, present and future. Nature Medicine Supplement. 2005;11(4):5-11. DOI: 10.1038/nm1209.

Portal da Prefeitura da Cidade de São Paulo [Internet]. São Paulo; 2014. [atualizado 2014; citado 2014 out. 1]. Disponível em: http://www.prefeitura.sp.gov.br/cidade/secretarias/saude/epidemiologia e informaca o/informacoes socioambientais/index.php? $\mathrm{p}=8452 \# 06$.

Porto MY. Uma revolta popular contra a vacinação. São Paulo. Cienc. Cult.2003;55(1). [citado 2018 set. 19]. Disponível em: 
http://cienciaecultura.bvs.br/scielo.php?pid=S0009-

$67252003000100032 \&$ script=sci_arttext\&tlng=pt

Ramos CF, Paixão JGM, Donza FCS, Silva AMP, Caçador DF, Dias VDV, Sodré EFLM. Cumprimento do calendário de vacinação de crianças. Rev Pan-Amaz Saúde. 2010;1(2):55-60.

Ribeiro FA. Atenção Primária (APS) e Sistema de Saúde no Brasil: uma perspectiva histórica [dissertação]. São Paulo: Faculdade de Medicina, Universidade de São Paulo; 2007.

Sato APS. Qual a importância da hesitação vacinal na queda das coberturas vacinais no Brasil?. Rev. Saúde Pública. 2018;52:96.

Santos QCL. Vigilância em saúde e participação social na perspectiva do território em transformação [dissertação]. Rio de Janeiro: Escola Nacional de Saúde Pública Sérgio Arouca, Fundação Oswaldo Cruz; 2013.

Silva JAM, Peduzzi M. Educação no Trabalho na Atenção Primária à Saúde: interfaces entre a educação permanente em saúde e o agir comunicativo. Saúde Soc. $2011 ; 20(4), 1018-32$.

São Paulo. Secretaria Municipal de Saúde, Coordenação da Atenção Básica/ Estratégia Saúde da Família. Manual Técnico/Auxiliar de Enfermagem. 2 ed. São Paulo; 2012.

São Paulo. Secretaria Municipal da Saúde, Coordenação de Epidemiologia e Informação - CEInfo. Boletim CEInfo Saúde em Dados | Ano XVII, no 17, Junho 2018. São Paulo; 2018. [citado 2019 jan.16]. Disponível em: https://www.prefeitura.sp.gov.br/cidade/secretarias/saude/epidemiologia_e_informac ao/index.php?p=258529

São Paulo. Secretaria Municipal de Saúde, Coordenação de Epidemiologia e Informação (CEInfo). Estabelecimentos e Serviços de Saúde [Internet] . São Paulo; 2018 [atualizado 2018 set. 19; citado 2019 jan. 16]. Disponível em: https://www.prefeitura.sp.gov.br/cidade/secretarias/saude/epidemiologia e informac ao/informacoes assistenciais/index.php? $\mathrm{p}=30566$

São Paulo. Secretaria Municipal de Saúde, Coordenação de Epidemiologia e Informação (CEInfo). Estabelecimentos e Serviços de Saúde da Rede Municipal Coordenadoria Regional de Saúde Sul [Internet] . São Paulo; 2018 [atualizado 2018 set; citado 2019 jan. 16]. Disponível em: https://www.prefeitura.sp.gov.br/cidade/secretarias/upload/saude/arquivos/ceinfo/ma poteca/crs_sul_sts.pdf

São Paulo. Secretaria Municipal de Saúde, Coordenação de Epidemiologia e Informação (CEInfo). Relação dos Estabelecimentos/Serviços da Secretaria Municipal de Saúde por Coordenadoria Regional de Saúde e Supervisão Técnica de Saúde [Internet]. São $\quad$ Paulo; $2018 . \quad$ Disponível em: 
https://www.prefeitura.sp.gov.br/cidade/secretarias/upload/saude/arquivos/organizac ao/Unid_Munic_Saude_Super.pdf

São Paulo. Secretaria Municipal de Saúde, Coordenação de Epidemiologia e Informação (CEInfo). Tabnet. Serviços Especializados do CNES - Município de São Paulo [Internet]. São Paulo; 2019. [citado 2019 jan.16]. Disponível em: http://tabnet.saude.prefeitura.sp.gov.br/cgi/deftohtm3.exe?secretarias/saude/TABNE T/cnes/servi.def

São Paulo. Secretaria Municipal de Saúde, Coordenação de Epidemiologia e Informação (CEInfo) [Internet] . São Paulo; n.d. [atualizado 2016; citado 2016 fev. 08]. Disponível em: http://www.prefeitura.sp.gov.br/cidade/secretarias/saude/epidemiologia e informaca o/index.php? $\mathrm{p}=19518$.

São Paulo. Secretaria Municipal de Saúde, Coordenadoria de Epidemiologia e Informação. Indicadores para Diagnóstico Sintético da Saúde: Cidade de São Paulo 2004-2011. São Paulo; 2013.

São Paulo. Secretaria Municipal de Saúde, Coordenadoria de Epidemiologia e Informação. $N^{\circ}$ de Estabelecimentos/Serviços próprios da SMS por Coordenadoria Regional de Saúde e Supervisão Técnica - Agosto de 2014. São Paulo; 2014. [citado 2014 out. 1]. Disponível em: http://www.prefeitura.sp.gov.br/cidade/secretarias/upload/saude/arquivos/organizaca o/TabelaEstabServCRSSTS.pdf

Souza AC. Análise do Programa Nacional de Imunização no Estado de Mato Grosso, 2006-2008 [dissertação]. São Paulo: Faculdade de Ciências Médicas da Santa Casa de São Paulo;2010.

Souza IBJ, Lago EC, Araújo TME, Almeida CAPL, Tapety FI, Carvalho ML. Conhecimento de enfermeiros e médicos de uma microrregião do Nordeste brasileiro sobre a vacinação infantil. Nursing, 2018;21(247):2498-505.

Tauil MC. Cobertura vacinal e fatores associados à vacinação incompleta em município de médio porte, Estado de São Paulo, Brasil [tese]. São Paulo: Faculdade de Ciências Saúde Pública da Universidade de São Paulo;2017.

Tauil MC, Sato APS, Inenami AACM, Ferreira VLR, Waldman EA . Coberturas vacinais por doses recebidas e oportunas com base em um registro informatizado de imunização, Araraquara-SP, Brasil, 2012-2014. Epidemiol. Serv. Saúde. 2017;26(4).

Teixeira A. Fake news contra a vida: desinformação ameaça vacinação de combate à febre amarela [dissertação]. São Paulo, Pontífica Universidade Católica de São Paulo,2018.

Vasconcellos-Silva PR, Castiel LD, Griep RH. A sociedade de risco midiatizada, o movimento antivacinação e 0 risco do autismo. Ciência Saúde Coletiva. 2015;20(2):607-16. 
Yokokura AVCP, Silva AAM, Bernardes ACF, Lamy Filho F, Alves MTSSB, Cabra $N A L$, et. al. Cobertura vacinal e fatores associados ao esquema vacinal básico incompleto aos 12 meses de idade, São Luís, Maranhão, Brasil, 2006. Cad. saúde pública. 2013;29(3):522-34. DOI: 10.1590/S0102-311X2013000300010. 


\section{APÊNDICE A - Questionário}

Prezado participante do estudo, este questionário é o instrumento para coleta de dados da pesquisa intitulada "Conhecimento sobre as verdadeiras e falsas contraindicações às imunizações em uma Unidade Básica de Saúde". Nosso objetivo é levantar o seu conhecimento sobre o tema, a fim aprimorá-lo.

Sendo assim, solicitamos que você o preencha individualmente e sem consulta à literatura (física ou eletrônica).

Data:

\section{Questões sobre você:}

1. Em qual faixa etária você se enquadra?

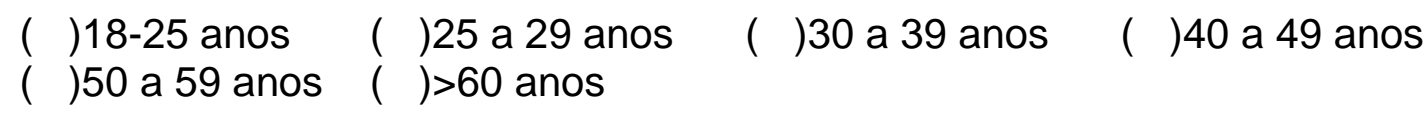

2. Qual a sua formação?

( ) Ensino Médio Completo

( )Ensino Técnico em Área da Saúde Incompleto

( )Ensino Técnico em Área da Saúde Completo

( )Ensino Superior em Área da Saúde Incompleto

( ) Ensino Superior em Área da Saúde Completo

( ) Ensino Técnico em Outra Área Incompleto

( ) Ensino Técnico em Outra Área Completo

( )Ensino Superior em Outra Área Incompleto

( ) Ensino Superior em Outra Área Completo

3. Qual a função que você de desenvolve na Unidade Básica de Saúde?

( ) Enfermeiro

( )Auxiliar de Enfermagem

( ) Agente Comunitário de Saúde

4. Há quanto tempo trabalha nesta função?

( ) $<1$ ano ( )1-3 anos ( )4-9 anos ( ) >10 anos

5. Você já passou por algum treinamento, curso, oficina sobre vacinação? 
( ) Sim

( )Não

Leia com atencão cada questão abaixo e assinale a alternativa que julgar correta. Só responda "Não Sei", se não tiver nenhuma nocão sobre a resposta. Na dúvida, por favor, opte por "Sim" ou "Não".

1. Você orienta o responsável pela criança a deixar de vaciná-la em alguma situação?

( )Não

( ) Sim. Em qual(is) situação(ões)?

2. Você orienta o responsável pela criança a adiar sua vacinação em alguma situação?

( )Não

( )Sim. Em qual(is) situação(ões)?

3. É importante que mãe ou responsável pela criança conheça sobre as doenças que podem ser evitadas por vacinação?

( ) Sim ( )Não ( )Não sei

4. Se a criança receber a primeira dose de uma vacina contra alguma doença, ela já está completamente protegida?

( ) Sim ( )Não ( )Não sei 
5. Se em uma cidade, a maior parte das crianças estiver vacinada adequadamente contra uma determinada doença, esta deixa de existir nesse local?
( ) Sim
( )Não
( )Não sei

6. As crianças morrem menos se são mais vacinadas?
( ) Sim
( )Não
( )Não sei

7. Vacinar as crianças com pouca idade pode ser perigoso porque elas ainda não conseguem reagir bem às vacinas?
( ) Sim
( )Não
( )Não sei

8. A equipe de saúde deve se responsabilizar pela busca de crianças faltosas em relação à vacinação?
( ) Sim
( )Não
( )Não sei

9. A equipe de saúde é responsável pela orientação aos pais sobre as vacinas e as doenças que podem ser evitadas pela vacinação?
( ) Sim
( )Não
( )Não sei

10.O acompanhamento da situação vacinal das crianças na área onde sua equipe atua é responsabilidade apenas da enfermeira da equipe?
( ) Sim
( )Não
( )Não sei

11. Pais ou responsáveis deixam de vacinar suas crianças por acreditarem que a vacinação não é importante para a saúde da criança?
( ) Sim
( )Não
( )Não sei

12. Esquecer de levar a criança para tomar as doses de reforço interfere no esquema vacinal?
( ) Sim
( )Não
( )Não sei

13. Se uma criança vai à unidade de saúde, e a equipe de saúde não avalia sua situação vacinal, essa pode ser uma oportunidade de vacinar que foi perdida?
( ) Sim
( )Não
( )Não sei 
14. As crianças com vacinas em atraso, podem receber todas as vacinas ao mesmo tempo?
( ) Sim
( )Não
( )Não sei

15. A falta de registro, ou o registro incorreto ou incompleto das doses de vacina aplicadas dificulta o acompanhamento da situação vacinal da criança?
( ) Sim
( )Não
( )Não sei

16. Não permitir a vacinação de uma criança aumenta o risco de outras crianças adquirirem uma doença?
( ) Sim
( )Não
( ) Não sei

17. Crianças que tem alguma contraindicação a receber determinadas vacinas são beneficiadas de alguma forma pelas crianças que são vacinadas?
( ) Sim
( )Não
( ) Não sei

18. Recusar a vacinação das crianças pode fazer com que as doenças que já não estão presentes possam ser reintroduzidas?
( ) Sim
( ) Não
( )Não sei

19. A falta de acolhimento dos profissionais no serviço de saúde atrapalha o cumprimento do calendário de vacinação pelos pais ou responsáveis pela criança?
( ) Sim
( )Não
( )Não sei

20. Se a criança teve alguma reação à vacinação, isso pode atrapalhar a tomada das vacinas futuras?
( ) Sim
( )Não
( ) Não sei

21. A crença de que as vacinas não são efetivas para a proteção da criança diminui a chance de tomar as vacinas futuras?
( ) Sim
( )Não
( )Não sei

22. Existe um controle de qualidade das vacinas que são aplicadas nas unidades de saúde do SUS?
( ) Sim
( )Não
( )Não sei 
23. Todas as pessoas vacinadas desenvolvem imunidade contra a doença contra a qual recebeu a vacina?
( )Sim
( )Não
( )Não sei

24. Relacione as colunas com os imunobiológicos e as doenças contra as quais eles protegem:
a) $B C G$
1) Poliomielite
b) Pentavalente
2) Difteria, Tétano, Coqueluche
c) VIP e VOP
3) Sarampo, caxumba, rubéola e varicela
d) Pneumo 10
4) Meningite meningocócica
e) Rotavírus
5) Formas graves de tuberculose
f) Meningo C
6) Pneumonia, meningite, sepse
g) Tríplice Viral
7) Gastroenterites
h) Tríplice bacteriana
8) Sarampo, caxumba e rubéola
i) Tetraviral
9) Difteria, Tétano, Coqueluche, infecções por Haemophilus, Hepatite B

Respostas:
a)
b)
c)
d)
e)
f)
g)
h)
i) 


\section{APÊNDICE B - Parecer consubstanciado CEP}

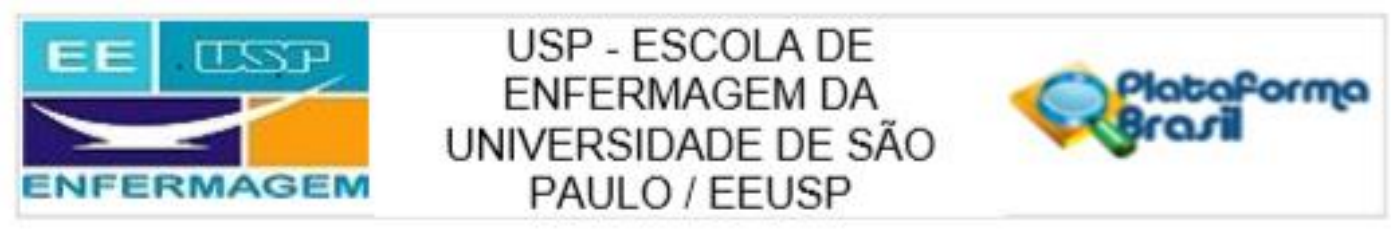

\section{PARECER CONSUBSTANCIADO DO CEP}

\section{DADOS DO PROJETO DE PESQUISA}

Título da Pesquisa: Conhecimento sobre as verdadeiras e falsas contraindicações às imunizações em uma Unidade Básica de Saúde

Pesquisador: RENATA HOLANDA DOS ANJOS LIMA

Área Temática:

Versão: 1

CAAE: 16498919.3 .0000 .5392

Instituição Proponente: Escola de Enfermagem da Universidade de São Paulo - EEUSP

Patrocinador Principal: Financiamento Próprio

\section{DADOS DO PARECER}

Número do Parecer: 3.519 .686

Apresentação do Projeto:

Trata-se de Projeto de Pesquisa apresentado ao Programa de Pós-Graduação Mestrado Profissional em Enfermagem na Atenção Primária em Saúde no Sistema Ủnico de Saúde da Escola de Enfermagem da Universidade de São Paulo intitulado "Conhecimento sobre as verdadeiras e falsas contraindicações às imunizaçōes em uma Unidade Básica de Saúde", desenvolvida pela Mestranda Renata Holanda dos Anjos Lima, sob orientação do Prof. Dr. Francisco Oscar de Siqueira França, tendo como coorientadora a Dra Eloả Otrenti.

Objetivo da Pesquisa:

Identificar o conhecimento da equipe de enfermagem e dos agentes comunitários de saúde a respeito de imunizações, em uma UBS na Região Sul do município de São Paulo, por meio da entrevista potencial de todos os enfermeiros, auxiliares de enfermagem e ACS que atuam na ESF, na unidade campo de estudo.

\section{Avaliação dos Riscos e Benefícios:}

Riscos:

O estudo não envolve risco. Pode ser que o participante sinta algum desconforto em responder ao questionário, ou ao participar da oficina, por exemplo, se tiver alguma dúvida sobre o tema. Caso isso ocorra, a pesquisadora se disponibiliza a conversar a respeito, de forma a esclarecer eventuais dúvidas.

Enderę̧o: Av. Dr. Enéas de Carvaiho Aguiar, 419

Bairro: Cenqueira Cesar

UF: SP Municiplo: SAO PAULO

CEP: $05403-400$

Telefone: (11)3061-BasB

E-mall: cepeegusp br 


USP - ESCOLA DE
ENFERMAGEM DA
UNIVERSIDADE DE SÃO
PAULO/EEUSP

Centinuaçate co Parecer: 3.519 .686

\section{Benefícios:}

A pesquisadora destaca como benefício desta pesquisa, ajudar a colocar em evidência a participação da equipe de enfermagem e do ACS na educação em saúde, o que contribui para a adesão às ações de vacinação.

\section{Comentários e Considerações sobre a Pesquisa:}

Serão entrevistados 63 profissionais, que deverăo responder a um questionário devidamente anexado à Plataforma e que versa sobre a atividade de imunização e conscientização dos imunizandos e seus familiares por referidos profissionais. Depois do preenchimento, será agendada uma oficina de esclarecimento, em intervalo de aproximadamente uma semana. Logo após a oficina, o profissional deverá responder ao mesmo questionário e as respostas serão comparadas para se verificar a seguinte hipótese de pesquisa: "Há um déficit no conhecimento da equipe de enfermagem e dos agentes comunitários de saúde a respeito de imunizações, principalmente em relação às verdadeiras e falsas contraindicações à vacinação."

Considerações sobre os Termos de apresentação obrigatória:

Consta a folha de rosto, documento da Secretaria Municipal de Saúde, questionário a ser aplicado e TCLE. Este último está redigido de forma clara e direta e contém os dados relevantes para a obtenção do Consentimento do entrevistado.

Recomendações:

Não há.

Conclusỗes ou Pendências e Lista de Inadequações:

Não há.

Considerações Finais a critério do CEP:

Este CEP informa a necessidade de registro dos resultados parciais e finais na Plataforma Brasil. Esta aprovação não substitui a autorização da instituição coparticipante, antes do início da coleta de dados.

Este parecer foi elaborado baseado nos documentos abaixo relacionados:

\begin{tabular}{|l|l|c|c|c|}
\hline \multicolumn{1}{|c|}{ Tipo Documento } & \multicolumn{1}{|c|}{ Arquivo } & Postagem & Autor & Situação \\
\hline $\begin{array}{l}\text { Informaçóes Básicas } \\
\text { do Projeto }\end{array}$ & $\begin{array}{l}\text { PB_INFORMACOEES_BASICAS_DO_P } \\
\text { ROJETO_1382013 pdf }\end{array}$ & $\begin{array}{c}27 / 06 / 2019 \\
06: 59: 00\end{array}$ & & Aceito \\
\hline
\end{tabular}

Enderę̧o: Av. Dr. Enéas de Carvalho Aguiar, 419

Bairro: Cerqueira Cesar

CEP: $05.403-000$

Telefone: (11)3061-Bas:

E-mall: cepengusp br 


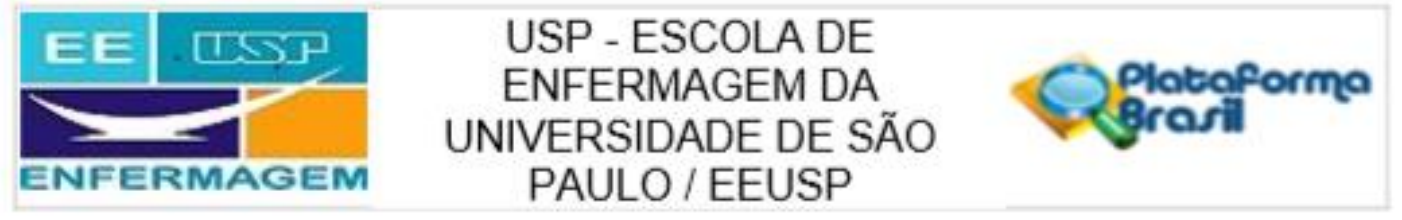

Continuaçầ đo Parecer 3.519 .686

\begin{tabular}{|c|c|c|c|c|}
\hline Outros & $\begin{array}{l}\text { QUESTIONARIO_Conhecimento_sobre } \\
\text { as_verdadeiras_e_falsas_contraindicad } \\
\text { oes_as_imunizacoes_em_uma_Unidade } \\
\text { Basica_de Saude_docx }\end{array}$ & $\begin{array}{c}27 / 06 / 2019 \\
06.56 .50\end{array}$ & $\begin{array}{l}\text { RENATA HOLANDA } \\
\text { DOS ANJOS LIMA }\end{array}$ & Aceito \\
\hline $\begin{array}{l}\text { Projeto Detalhado / } \\
\text { Brochura } \\
\text { Investigador }\end{array}$ & $\begin{array}{l}\text { PROJETO_DE_PESQUISA_Conhecime } \\
\text { nto_sobre_as_verdadeiras_e_falsas_co } \\
\text { ntraindicacoes_as_imunizacoes_em_um } \\
\text { a Unidade Basica de Saude.docx }\end{array}$ & $\begin{array}{c}27 / 06 / 2019 \\
06: 56: 29\end{array}$ & $\begin{array}{l}\text { RENATA HOLANDA } \\
\text { DOS ANJOS LIMA }\end{array}$ & Aceito \\
\hline Outros & $\begin{array}{l}\text { CARTA_DE_AUTORIZACAO_CRS_SU } \\
\text { L_Conhecimento_sobre_as_verdadeiras } \\
\text {-e_falsas_contraindicacoes_as_imuniza } \\
\text { coes_em_uma_Unidade_Basica_de_Sa } \\
\text { ude.pdf }\end{array}$ & $\begin{array}{c}27 / 06 / 2019 \\
06: 55: 05\end{array}$ & $\begin{array}{l}\text { RENATA HOLANDA } \\
\text { DOS ANJOS LIMA }\end{array}$ & Aceito \\
\hline $\begin{array}{l}\text { TCLE / Termos de } \\
\text { Assentimento / } \\
\text { Justificativa de } \\
\text { Ausência }\end{array}$ & $\begin{array}{l}\text { TCLE_Conhecimento_sobre_as_verdad } \\
\text { eiras_e_falsas_contraindicacoes_as_im } \\
\text { unizacoes_em_uma_Unidade_Basica_d } \\
\text { e Saude.docx }\end{array}$ & $\begin{array}{c}27 / 06 / 2019 \\
06: 54: 00\end{array}$ & $\begin{array}{l}\text { RENATA HOLANDA } \\
\text { DOS ANJOS LIMA }\end{array}$ & Aceito \\
\hline Orçamento & $\begin{array}{l}\text { ORCAMENTO_Conhecimento_sobre_as } \\
\text {-verdadeiras_e_falsas_contraindicacoes } \\
\text {-as_imunizacoes_em_uma_Unidade_B } \\
\text { asica de Saude_docx }\end{array}$ & $\begin{array}{l}27 / 06 / 2019 \\
06.53: 05\end{array}$ & $\begin{array}{l}\text { RENATA HOLANDA } \\
\text { DOS ANJOS LIMA }\end{array}$ & Aceito \\
\hline Cronograma & $\begin{array}{l}\text { CRONOGRAMA_Conhecimento_sobre_- } \\
\text { as_verdadeiras_e_falsas_contraindicaco } \\
\text { es_as_imunizacoes_em_uma_Unidade_- } \\
\text { Basica de Saude_docx }\end{array}$ & $\begin{array}{c}27 / 06 / 2019 \\
06: 52: 47\end{array}$ & $\begin{array}{l}\text { RENATA HOLANDA } \\
\text { DOS ANJOS LIMA }\end{array}$ & Aceito \\
\hline Folha de Rosto & $\begin{array}{l}\text { Folha_de_Rosto_Renata_Holanda_dos__ } \\
\text { Anios_Lima.pdf }\end{array}$ & $\begin{array}{c}24 / 06 / 2019 \\
20-36: 01\end{array}$ & $\begin{array}{l}\text { RENATA HOLANDA } \\
\text { DOS ANJOS LIMA }\end{array}$ & Aceito \\
\hline
\end{tabular}

Situação do Parecer:

Aprovado

Necessita Apreciação da CONEP:

Não

SAO PAULO, 20 de Agosto de 2019

Assinado por:

Márcia Aparecida Ferreira de Oliveira

(Coordenador(a))

Endereço: Av, Dr, Eneas de Carvalho Aguiar, 419

Bairro: Cerqueira Cesar

UF: SP MUNiciplo: SAO PAULO

CEP: 05 403-000

Telefone: (11)3081-BH58

E-mall: cepeegusp br 


\section{APÊNDICE C - Termo de Consentimento Livre e Esclarecido}

Convidamos o (a) Sr. (a) para participar da pesquisa intitulada "Conhecimento sobre as verdadeiras e falsas contraindicações às imunizações em uma Unidade Básica de Saúde", desenvolvida pela Sra. Renata Holanda dos Anjos Lima.

O objetivo do estudo é identificar o conhecimento da equipe de enfermagem e dos agentes comunitários de saúde a respeito de imunizações.

Este estudo tem três momentos: no primeiro, o Sr.(a) será convidado(a) a responder um questionário, que deve demorar aproximadamente 30 minutos, com a finalidade de identificar seu conhecimento sobre o tema vacinação. No segundo momento, o Sr.(a) será convidado(a) a participar de uma oficina para conversarmos a respeito do mesmo tema, que tem a finalidade de esclarecer dúvidas e melhorar o conhecimento a respeito da vacinação. No terceiro momento do estudo, o(a) convidamos para responder ao mesmo questionário aplicado no primeiro momento, com a finalidade de verificar se houve alguma mudança em termos do conhecimento sobre vacinação.

Para responder o questionário, o(a) S.(a) deverá levar aproximadamente 30 minutos. O questionário será aplicado uma semana antes de ocorrer a oficina, na Unidade Básica de Saúde (UBS) e a oficina ocorrerá na própria UBS, em horário previamente agendado, e deverá ter a duração de, aproximadamente uma hora. Logo a seguir, solicitaremos que o mesmo questionário seja respondido.

Tudo isso será combinado antes com a gerência da UBS, de forma a não comprometer o trabalho. Esclarecemos que esta pesquisa tem fins científicos e não está associada de nenhuma forma à avaliação de seu desempenho na unidade de saúde.

Destacamos como benefício desta pesquisa, ajudar a colocar em evidência a participação da equipe de enfermagem e do ACS na educação em saúde, o que contribui para a adesão às ações de vacinação.

$\mathrm{O}$ estudo não envolve risco. Pode ser que o(a) Sr.(a). sinta algum desconforto em responder ao questionário, ou ao participar da oficina, por exemplo, se tiver alguma dúvida sobre o tema. Caso isso ocorra, nos disponibilizamos a conversar a respeito, de forma a esclarecer eventuais dúvidas.

Ressaltamos que em caso de desconforto em algum momento de sua participação neste estudo, há possibilidade de não responder a alguma pergunta do questionário ou retirar seu consentimento na realização deste.

Esclarecemos que o (a) Sr. (a) tem plena liberdade de recusar-se a participar ou retirar seu consentimento, em qualquer fase do estudo, sem qualquer prejuízo em seu trabalho, e que é garantida a manutenção do seu anonimato e privacidade durante todas as fases do estudo.

O(a) Sr.(a) não terá nenhuma despesa por participar do estudo, pois será desenvolvido na própria unidade de saúde. $\mathrm{O}$ (a) $\mathrm{Sr}(\mathrm{a})$. tem a garantia de indenização, caso ocorram eventuais danos, comprovadamente decorrentes da pesquisa.

Este termo deve ser rubricado em todas as suas páginas e assinado nas duas vias. O (a) Sr. (a) receberá uma via assinada pela pesquisadora. 
Em qualquer etapa do estudo, o (a) Sr. (a) terá acesso à pesquisadora responsável para o esclarecimento de dúvidas.

Caso o(a) Sr.(a). tenha dúvidas sobre este estudo, entre em contato com a principal pesquisadora, Sra. Renata Holanda dos Anjos Lima, que pode ser encontrada na UBS Jardim Valquíria, no endereço: Avenida Carlos Lacerda, 3093 Jardim Valquíria - São Paulo/SP, pelo telefone: (11) 953477696, ou e-mail: renata.anjos@usp.br

Caso o(a) Sr.(a). tenha alguma consideração ou dúvida sobre a ética da pesquisa, entre em contato com o Comitề de Ética em Pesquisa (CEP) da Escola de Enfermagem da USP - Endereço: Av. Dr. Enéas de Carvalho Aguiar, 419 - Cerqueira Cesar - São Paulo/SP CEP - 05403-000, Telefone- (11) 3061-8858, e-mail: cepee@usp.br ou

Caso o(a) Sr.(a). tenha dúvidas e denúncias quanto às questões éticas, entre em contato com o Comitê de Ética em Pesquisas da Secretaria Municipal da Saúde de São Paulo, Rua General Jardim, 36, 8o andar. Telefone: (11) 3397-2464, e-mail: smscep@gmail.com.

Agradecemos sua participação!

Renata Holanda dos Anjos Lima - pesquisadora responsável

Assinatura do participante

Data: 